bioRxiv preprint doi: https://doi org/10.1101/2022.02 24.481804: this version posted February 25,2022 . The copyright holder for this preprint (which was not certified by peer review) is the author/funder, who has granted bioRxiv a license to display the preprint in perpetuity. It is made available under aCC-BY-NC-ND 4.0 International license.

Brock et al.

\title{
A role for thalamic projection GABAergic neurons in circadian responses to light
}

O. Brock ${ }^{1}$, C.E. Gelegen ${ }^{1+}$, I. Salgarella ${ }^{1+}$, P. Sully ${ }^{1+}$, P. Jager ${ }^{1}$, L. Menage ${ }^{1}$, I. Mehta ${ }^{1}$, J. Jęczmień-Łazur ${ }^{1}$, D. Djama ${ }^{1,2}$, L. Strother ${ }^{1}$, A. Coculla ${ }^{1}$, A. Vernon ${ }^{1,3}$, S. Brickley ${ }^{2}$, P. Holland ${ }^{1,4}$, S. Cooke $e^{1,3}$ and A. Delogu ${ }^{1 *}$

${ }^{1}$ School of Neuroscience, Institute of Psychiatry, Psychology and Neuroscience, King's College London, London SE5 9NU, United Kingdom

${ }^{2}$ Department of Life Sciences and Centre for Neurotechnology, Imperial College London, London SW7 2AZ, United Kingdom

${ }^{3}$ MRC Centre for Neurodevelopmental Disorders, King's College London, London SE1 1UL, United Kingdom

${ }^{4}$ Wolfson Centre for Age Related Disease, King's College London, London SE1 1UL, United Kingdom

+ equal contribution

${ }^{*}$ Author for correspondence (alessio.delogu@kcl.ac.uk) 
bioRxiv preprint doi: https://doi.org/10.1101/2022.02 24.481804 t this version posted February 25,2022 . The copyright holder for this preprint (which was not certified by peer review) is the author/funder, who has granted bioRxiv a license to display the preprint in perpetuity. It is made available under aCC-BY-NC-ND 4.0 International license.

Brock et al.

\section{Abstract}

The thalamus is an important hub for sensory information and participates in sensory perception, regulation of attention, arousal and sleep. These functions are executed primarily by glutamatergic thalamocortical neurons that extend axons to the cortex and initiate corticothalamocortical connectional loops. However, the thalamus also contains projection GABAergic neurons that do not engage in direct communication with the cortex. Here, we have harnessed recent insight into the development of the intergeniculate (IGL), the ventrolateral geniculate (LGv) and the perihabenula $(\mathrm{pHB})$ to specifically target and manipulate thalamic projection GABAergic neurons in female and male mice. Our results show that thalamic GABAergic neurons of the IGL and LGv receive retinal input from diverse classes of ipRGCs, but not from the M1 ipRGC type, while those in the pHB lack direct retinal input. We describe the synergistic role of the photoreceptor melanopsin and the thalamic neurons of the IGL/LGv in circadian entrainment to dim light. We identify a requirement for the thalamic IGL/LGv in the rapid changes in vigilance states associated with circadian light transitions. Furthermore, we map a previously undescribed thalamic network of developmentally related GABAergic neurons in the IGL/LGv complex and the pHB potentially involved in light-dependent mood regulation.

Keywords: thalamus, intergeniculate leaflet, ventral lateral geniculate, perihabenula, melanopsin, ipRGCs, sleep, circadian entrainment, vigilance states, EEG, mood.

\section{Significance statement}

The intergeniculate leaflet and ventral geniculate nucleus are part of the extended circadian system and mediate some non-image-forming visual functions. Here we show that each of these structures has a thalamic (dorsal) as well as prethalamic (ventral) developmental origin. 
bioRxiv preprint doi: https://doi.org/10.1101/2022.02.24.481804: this version posted February 25, 2022. The copyright holder for this preprint (which was not certified by peer review) is the author/funder, who has granted bioRxiv a license to display the preprint in perpetuity. It is made available under aCC-BY-NC-ND 4.0 International license.

Brock et al.

We map the retinal input to thalamus-derived cells in the IGL/LGV complex and discover that while ipRGC input is dominant, this is not likely to originate from M1-ipRGCs. We describe the extent of similarity in synaptic input to developmentally related cells in the IGL/LGV and in the perihabenula nucleus (pHB). We implicate thalamic cells in the IGL/LGv in vigilance state transitions at circadian light changes and in overt behavioural entrainment to dim light, the latter exacerbated by concomitant loss of melanopsin expression. 
bioRxiv preprint doi: https://doi.org/10.1101/2022.02.24.481804 t this version posted February 25,2022 . The copyright holder for this preprint (which was not certified by peer review) is the author/funder, who has granted bioRxiv a license to display the preprint in perpetuity. It is made available under aCC-BY-NC-ND 4.0 International license.

Brock et al.

\section{Introduction}

GABAergic projection neurons are present at the rostroventral and dorsocaudal edges of the mouse thalamus to form the intergeniculate leaflet (IGL) (Morin and Blanchard, 1999, 2001, 2005) and perihabenula nucleus (pHB) (An et al., 2020; Fernandez et al., 2018), respectively. Contiguous with the IGL, but within the largely GABAergic prethalamic territory, is the ventral lateral geniculate nucleus (LGv) (Monavarfeshani et al., 2017; Moore et al., 2000; Morin and Blanchard, 2005; Sabbagh et al., 2020). Despite their largely distinct ontogeny (Delogu et al., 2012; Inamura et al., 2011; Jeong et al., 2011; Puelles et al., 2020; Suzuki-Hirano et al., 2011; Virolainen et al., 2012; Vue et al., 2007; Yuge et al., 2011), functional studies have often grouped the IGL and LGv together, based on GABA expression, anatomical proximity and, to some degree, shared patterns of connectivity.

The IGL and LGv are the source of the geniculohypothalamic tract (Harrington, 1997; Moore, 1989; Morin and Blanchard, 1999, 2001; Pu and Pickard, 1996) that enables regulation of the circadian clock in the suprachiasmatic nucleus (SCN) (Harrington and Rusak, 1986; Johnson et al., 1989; Lewandowski and Usarek, 2002)(Fernandez et al., 2020; Hanna et al., 2017; Huhman and Albers, 1994; Huhman et al., 1995; Huhman et al., 1996; Shibata and Moore, 1993). The geniculohypothalamic tract is believed to be the conduit for integrated photic (Harrington and Rusak, 1989; Morin and Studholme, 2014b; Zhang and Rusak, 1989) and non-photic (Janik and Mrosovsky, 1994; Johnson et al., 1988; Kuroda et al., 1997; Marchant et al., 1997; Maywood et al., 2002; Maywood et al., 1997) cues that contribute to circadian entrainment to relevant external and internal variables. Retinal input is mostly from intrinsically photosensitive retinal ganglion cells (ipRGCs) (An et al., 2020; Beier et al., 2020; Fernandez et al., 2018; Guler et al., 2008; Hattar et al., 2006; Huang et al., 2019), while non-photic cues are thought to propagate via neurons of the ascending arousal system (Blasiak and Lewandowski, 
bioRxiv preprint doi: https://doi.org/10.1101/2022.02 24.481804 t this version posted February 25, 2022. The copyright holder for this preprint (which was not certified by peer review) is the author/funder, who has granted bioRxiv a license to display the preprint in perpetuity. It is made available under aCC-BY-NC-ND 4.0 International license.

Brock et al.

2003; Marchant et al., 1997; Meyer-Bernstein and Morin, 1996; Smith et al., 2015; Vrang et al., 2003).

Neurons in the IGL/LGv were shown to participate in mood regulation via inhibitory synapses onto lateral habenula (LH) neurons (Huang et al., 2019) and to contribute to photosomnolence in mice exposed to unexpected light at night (Shi et al., 2020). Related mood-regulatory functions are attributed to the pHB (An et al., 2020; Fernandez et al., 2018). Thalamic GABAergic projection neurons are specified during embryonic development within the rostral portion of the second diencephalic prosomere (p2) (Kataoka and Shimogori, 2008; Martinez-Ferre and Martinez, 2012; Nakagawa, 2019; Puelles, 2019; Puelles and Rubenstein, 1993, 2003; Rubenstein et al., 1994; Vue et al., 2007) and can be defined by expression of the transcription factor gene Sox14 (Delogu et al., 2012; Sellers et al., 2014; Virolainen et al., 2012; Vue et al., 2007). Tangential cell migration during embryogenesis distributes thalamic GABAergic precursors from the prospective IGL, to the developing LGv and pHB (Delogu et al., 2012). Hence, the mature IGL, LGv and pHB are characterised by a heterogenous cellular composition that includes Sox $14^{+}$GABAergic thalamic neurons. While the sparse interneurons of the mouse thalamocortical nuclei also express Sox14, these local circuit cells have a distinctive mesencephalic origin (Jager et al., 2021; Jager et al., 2016).

Here, we used stereotaxic injections in the Sox $14^{\text {Cre }}$ mouse to enable the characterisation of the thalamic component of anatomical regions with complex embryonic ontogeny. We demonstrate that circadian optogenetic stimulation of the Sox $14^{+}$neurons in the IGL/LGv is sufficient to reset circadian motor activity rhythms in the absence of other light cues. Upon cell ablation, we show that the thalamic component of the IGL/LGv plays a synergistic role with melanopsin photodetection to ensure photoentrainment to dim light and participates in the regulation of vigilance state transitions. We map synaptic input to thalamic Sox $14^{+}$ 
bioRxiv preprint doi: https://doi.org/10.1101/2022.02.24.481804; this version posted February 25, 2022. The copyright holder for this preprint (which was not certified by peer review) is the author/funder, who has granted bioRxiv a license to display the preprint in perpetuity. It is made available under aCC-BY-NC-ND 4.0 International license.

Brock et al.

neurons in the IGL/LGv and pHB and provide evidence of a potential new pathway for mood regulation. 
bioRxiv preprint doi: https://doi.org/10.1101/2022.02 24.481804 this version posted February 25,2022 . The copyright holder for this preprint (which was not certified by peer review) is the author/funder, who has granted bioRxiv a license to display the preprint in perpetuity. It is made available under aCC-BY-NC-ND 4.0 International license.

Brock et al.

\section{Results}

\section{The IGL/LGv complex contains cells of thalamic as well as prethalamic origins}

The IGL and the LGv are thought to arise from distinct progenitor domains in the thalamic prosomere 2 and prethalamic prosomere 3, respectively (Kataoka and Shimogori, 2008; Puelles et al., 2013; Virolainen et al., 2012; Vue et al., 2007). We and others have shown that radial migration of prosomere 2 Sox $14^{+}$precursors into the thalamic mantle zone generates the IGL primordium (Delogu et al., 2012; Jeong et al., 2011; Vue et al., 2007). In the developmental window between gestational day (E) E11.5-E14.5, different subsets of Sox14 neurons display tangential migratory behaviour from this location, reaching the thalamusepithalamus border first, at E12.5 to coalesce in the presumptive pHB nucleus (Fig. 1A) and then, in a subsequent wave of rostroventral migration, seeding the presumptive LGv with neurons of thalamic origin (Delogu et al., 2012; Jeong et al., 2011; Virolainen et al., 2012; Vue et al., 2007) (Fig. 1A,Q). To assess whether prethalamic neurons also contribute to the mature IGL (Fig. 1A), we mapped the fate of prethalamic GABAergic lineages in the IGL at postnatal day 21 (P21), using the prethalamic Cre-driver mouse line DIx5/6 Cre (Jager et al., 2021; Monory et al., 2006; Puelles et al., 2020) crossed with the conditional reporter line Rosa26-CAGSun1/sfGFP (R26 Isl-nGFP) (Mo et al., 2015). To assist with the anatomical delineation of the IGL, we co-labelled coronal tissue sections of the lateral geniculate with an antibody against neuropeptide $Y(\mathrm{Npy})$, a known marker for a subset of IGL neurons, and counted the proportion of neurons $\left(\mathrm{NeuN}^{+}\right)$within $\mathrm{IGL}$ boundaries that have prethalamic origin $\left(\mathrm{NeuN}^{+} \mathrm{nGFP}^{+}\right.$; Fig. 1B). This analysis revealed that about a quarter of the neurons in the IGL are of prethalamic origin (Fig. 1C; $25.69 \% \pm 1.17 \%$, mean \pm s.e.m., $n=3$ mice). The calcium binding proteins calbindin (Calb1) and parvalbumin (Pvalb) mark different cell types in the mature IGL/LGv complex (Sabbagh et al., 2020). Using the Sox14 ${ }^{G f p /+}$ (Delogu et al., 2012) and 
bioRxiv preprint doi: https://doi.org/10.1101/2022.02.24.481804 t this version posted February 25, 2022. The copyright holder for this preprint (which was not certified by peer review) is the author/funder, who has granted bioRxiv a license to display the preprint in perpetuity. It is made available under aCC-BY-NC-ND 4.0 International license.

Brock et al.

the $D / \times 5 / 6^{\text {Cre }} ; R 26^{I S-n G F P}$ reporter lines to label thalamic and prethalamic IGL/LGv lineages, respectively, we noted a similar proportion of Calb1+ IGL/LGv neuron subsets in both developmental classes. In the IGL $61.40 \% \pm 5.46 \%$ of Calb1 ${ }^{+}$cells belonged to the thalamic Sox $14^{+}$developmental class and $23.53 \% \pm 1.94 \%$ to the prethalamic D/ $\times 5 / 6^{+}$class; in the LGV $8.1 \% \pm 5.56 \%$ belonged to the thalamic Sox $14^{+}$developmental class and $84.17 \% \pm 5.56 \%$ to the prethalamic $D / x 5 / 6^{+}$class (Fig. $1 \mathrm{D}, \mathrm{E}, \mathrm{F}, \mathrm{G}$; mean \pm s.e.m., $\mathrm{n}=3$ mice per genotype). The Pvalb ${ }^{+}$subtype was virtually absent from the IGL and found exclusively in LGv lineages of prethalamic origin (Fig. $1 \mathrm{H}, \mathrm{I}, \mathrm{J}, \mathrm{K} ; \mathrm{n}=3$ mice per genotype). Hence, while each developmental class clearly differentiates further into several molecularly and functionally distinct cell types (Morin and Blanchard, 1995; Morin and Blanchard, 2001; Sabbagh et al., 2020) conventional mature cell markers may not always reflect developmental origin (e.g. Calb1). Importantly, progenitors from the thalamic and prethalamic primordium contribute to the formation of the mature IGL and LGv without clear spatial segregation of developmental lineage classes between the two anatomical regions. To visualise the pattern of axonal projections from the Sox $14^{+}$IGL/LGv neurons in the mature brain, we injected a Cre-dependent adenoassociated virus (AAV) expressing a cell membrane localised GFP (Matsuda and Cepko, 2007) (AAV2/1 Ef1a-DIO-mGFP) in the IGL/LGv of Sox14 $4^{\text {Cre/+ }}$ mice (Jager et al., 2016) at weaning age and imaged the brain-wide extent of GFP-labelled axons 3 weeks later (Fig. 1L). Although we did not conduct a detailed analysis of axonal projections, we noted that overall, the pattern of efferent projections of the Sox $14^{+}$IGL/LGv neurons was consistent with earlier reports for the anatomically defined IGL and LGv (Moore et al., 2000; Morin and Blanchard, 1995; Morin and Blanchard, 1999, 2005). 
bioRxiv preprint doi: https://doi.org/10.1101/2022.02.24.481804; this version posted February 25, 2022. The copyright holder for this preprint (which was not certified by peer review) is the author/funder, who has granted bioRxiv a license to display the preprint in perpetuity. It is made available under aCC-BY-NC-ND 4.0 International license.

Brock et al.

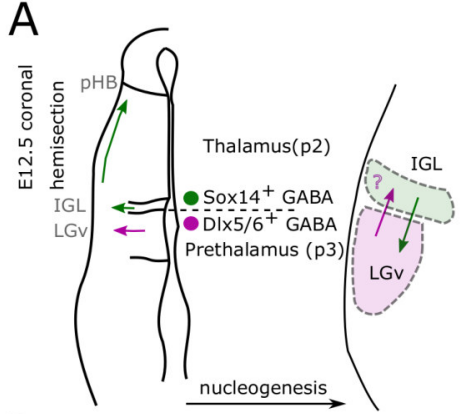

D

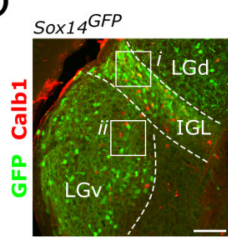

$\mathrm{H}$
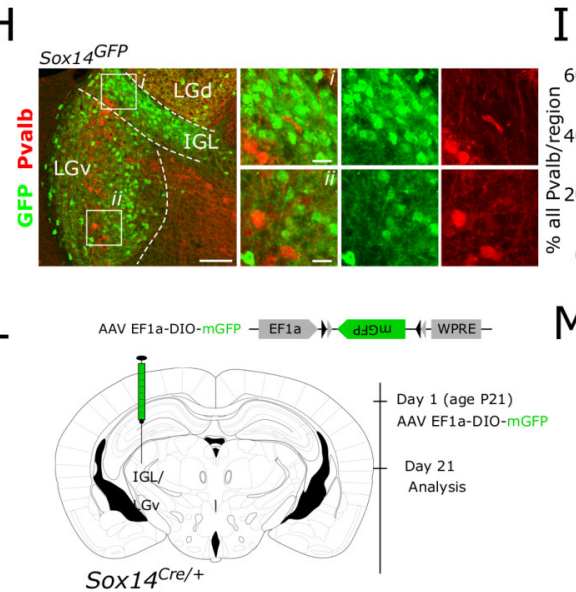

$\mathrm{N}$

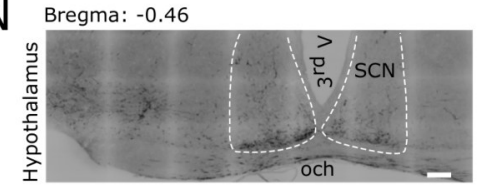

$\mathrm{O}$

Bregma: -0.94

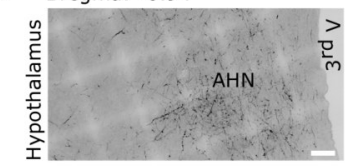

P Bregma: -2.30

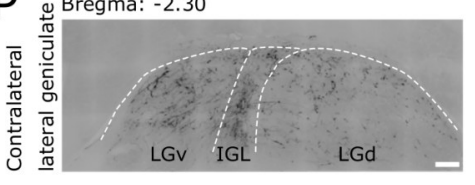

B

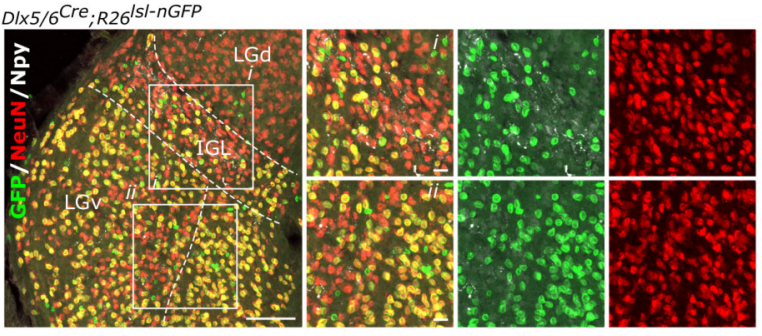

$\mathrm{E}$

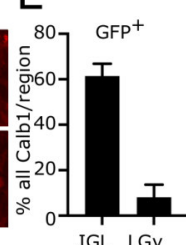

I

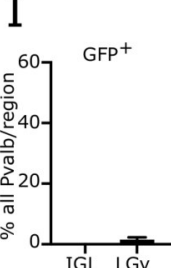

F

${ }_{D 1 \times 5 / 6^{C r e} ; R 26^{\mid S I-n G F P}}$
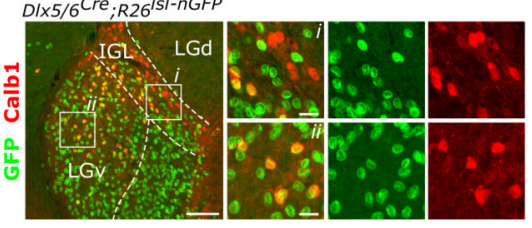

G

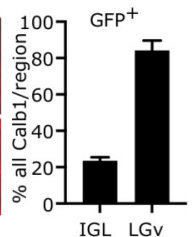

J

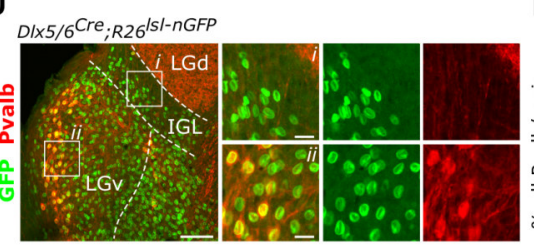

K

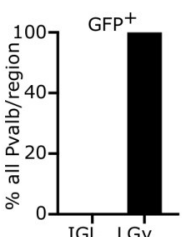

C

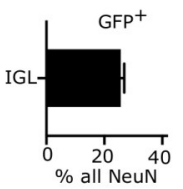

M

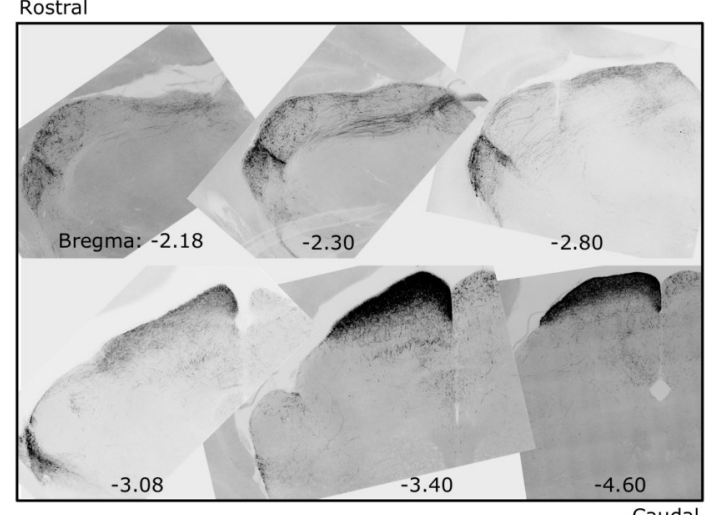

Q

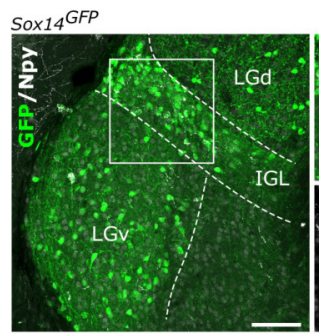

R

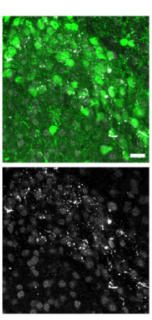

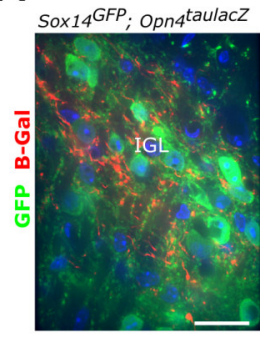

Cauda

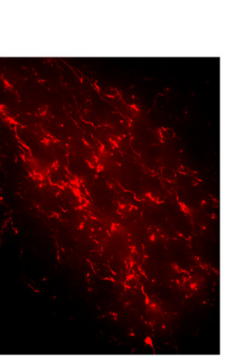

Figure 1.

Thalamic and prethalamic lineages in the IGL/LGv complex. A, schematic representation of the left diencephalon along the coronal plane at the time of peak embryonic neurogenesis (E12.5) illustrating the two main sources of GABAergic neurons for the IGL and the LGv. Radial migration of prethalamic (p3) GABAergic precursors (magenta) generates the bulk of the LGv, while radial migration of thalamic (p2) GABAergic precursors (green) generate the bulk of the IGL. Tangential migration of thalamic GABAergic precursors contributes to the formation of the $\mathrm{pHB}$ and to the cellular complexity of the LGv. The possibility of a complementary contribution of prethalamic GABAergic precursors to the IGL is tested using the prethalamic GABAergic driver $D / x 5 / 6^{\text {cre }}$. B, representative image illustrating the presence of neurons $\left(\mathrm{NeuN}^{+}\right)$with prethalamic origins $\left(\mathrm{GFP}^{+}\right)$in the IGL. Note the presence of NeuN ${ }^{+} G F P^{n e g}$ neurons in the LGv, consistent with the thalamic origin of some LGv neurons 
bioRxiv preprint doi: https://doi.org/10.1101/2022.02.24.481804; this version posted February 25, 2022. The copyright holder for this preprint (which was not certified by peer review) is the author/funder, who has granted bioRxiv a license to display the preprint in perpetuity. It is made available under aCC-BY-NC-ND 4.0 International license.

Brock et al.

and of NeuN ${ }^{\text {neg }} \mathrm{GFP}^{+}$glia in the LGd. C, quantification of the fraction of IGL neurons with prethalamic origin. $D, E$, representative images and quantification of the mosaic expression of the calbindin protein (Calb1) among thalamic $\left(\right.$ Sox $14^{G F P /+}$ ) lineages in the IGL and LGV. F,G, representative images and quantification of the mosaic expression of Calb1 in prethalamic $\left(D / \times 5 / 6^{\text {Cre }} ; R 26^{I S I-n G F P}\right.$ ) lineages in the IGL and LGv. $\boldsymbol{H}, \boldsymbol{I}, \boldsymbol{J}, \boldsymbol{K}$, representative images and quantification of the expression of Pvalb in thalamic and prethalamic lineages of the IGL and the LGv. $L$, schematic illustration of timeline of the AAV injection strategy used to label axonal projections of the Sox $14^{+}$IGL/LGv neurons in the adult brain. $\boldsymbol{M}$, inverted grey scale images from representative rostrocaudal levels of the IGL/LGv, demonstrating the widespread presence of dark GFP labelled fibres (see $L$ for strategy) projecting away from the IGL/LGv and towards other diencephalic and mesencephalic structures. $\mathbf{N}, \mathbf{O}, \boldsymbol{P}$, higher magnification images from the experiment in $L$ showing the presence of sparse GFP labelled fibres in the SCN, the AHN and the contralateral geniculate. $\boldsymbol{Q}$, an illustrative example of the location of thalamic Sox $14^{+}$neurons in the IGL and the LGv at 3 weeks of age. $R$, an example image showing the incoming ipRGC axons (b-gal) in the region occupied by Sox $14^{+}$neurons in the IGL using the Opn4 $4^{\text {taulacz/+}} ;$ Sox $14^{G F P /+}$ double transgenic mouse.

Notably, dense innervation was seen in the superficial gray and optic layers of the superior colliculus (Fig. 1M), while few immunoreactive fibres were present at the ventral edge of the SCN (Fig. 1N), sparse and diffuse in the hypothalamus (e.g. anterior hypothalamic nucleus, AHN, Fig. 10) and in all three subdivisions of the contralateral lateral geniculate (LGN, Fig. 1P).

We had previously shown that Sox $14^{+}$neurons in the IGL/LGv establish synaptic connectivity within the non-image-forming circuitry that mediates the pupillary light reflex (Delogu et al., 2012). Taking advantage of the strong GFP expression from the Sox $14^{G f p /+}$ mouse reporter line

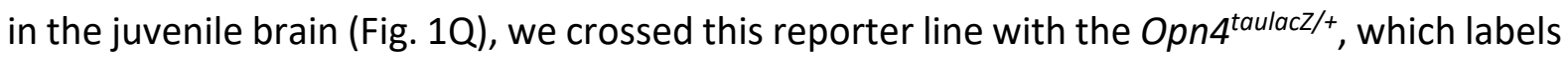
mostly the M1 subtype of ipRGCs (Baver et al., 2008; Hattar et al., 2006; Hattar et al., 2002). The Opn $4^{\text {taulacz/+}} ;$ Sox $14^{G f p /+}$ double transgenic mouse line confirmed the presence of $\mathrm{GFP}^{+}$ neurons within axonal projections labelled by the taulacZ reporter construct (Fig. 1R), consistent with several reports that propose M1 ipRGC innervation of the IGL/LGv. However, the discovery of additional prethalamic lineages in the IGL (Fig. 1B,C) raises the possibility that developmentally defined cell classes may receive selective ipRGC-subtype innervation. The Sox14Gfp and Sox14Cre mouse lines are suitable tools to resolve the developmental complexity of the IGL/LGv by restricting genetic labelling and manipulations exclusively to neurons of thalamic origin. 
bioRxiv preprint doi: https://doi.org/10.1101/2022.02 24.481804 t this version posted February 25,2022 . The copyright holder for this preprint (which was not certified by peer review) is the author/funder, who has granted bioRxiv a license to display the preprint in perpetuity. It is made available under aCC-BY-NC-ND 4.0 International license.

Brock et al.

\section{Retinal input to the Sox $14^{+}$IGL/LGv originates from non-M1 ipRGCs}

We sought to investigate the extent and diversity of retinal input to the thalamic component of the IGL/LGv, defined by Sox14 expression. For this purpose, we applied the modified rabies virus technology (Fig. 2A), guiding primary infection of a glycoprotein-deleted, GFP-expressing and avian-pseudotyped rabies (SADB19 $\triangle$ G-eGFP, EnvA; in short RVdG) to the Sox14 neurons of the IGL/LGv. Target neurons were primed for RVdG infection by stereotaxic injection in Sox $14^{\text {Cre/t }}$ transgenic mice of equimolar amounts of two Cre-dependent AAVs (Fig. 2A) expressing the avian receptor TVA linked via a self-cleavage peptide sequence to the red fluorescent reporter mCherry (AAV2/1 Ef1a-flex-TVA-mCherry) and the codon-optimised version of the rabies glycoprotein (G) gene (AAV2/1 CAG-flex-oG). Our injection strategy reliably targeted the IGL/LGv, as indicated by the cumulative total number of primary infected neurons $\left(\mathrm{GFP}^{+} \mathrm{mCherry}{ }^{+}\right.$; Fig. 2B) from all thalamus-containing sections in the target region (IGL: 308, LGv: 39; $n=6$ brains; Fig. 2C), while off target labelling was occasionally observed in some of the sparse Sox $14^{+}$thalamic interneurons along the trajectory of the stereotaxic injection (Fig. 2C; LGd, LP, NOT: 13; $n=6$ mice).

While it is known that M1 and non-M1 classes of melanopsin-type ipRGCs project to the IGL/LGv (Beier et al., 2020; Brown et al., 2010; Ecker et al., 2010; Hattar et al., 2006; Quattrochi et al., 2019; Stabio et al., 2018), it is unclear whether RGC subtype input to the IGL/LGv neurons correlates with the developmental origins of IGL/LGv cells. We therefore set out to investigate the transsynaptic spread of the RVdG to the retina and noted consistent labelling of these cells in the contralateral eye and to a lesser extent in the ipsilateral eye (Fig. 2D). Normalised RGC input was $0.56 \pm 0.18$ in the contralateral eye and $0.12 \pm 0.06$ in the ipsilateral eye (Fig. 2E; input per starter cell; mean \pm s.e.m, $n=6$ mice). 
bioRxiv preprint doi: https://doi.org/10.1101/2022.02.24.481804; this version posted February 25, 2022. The copyright holder for this preprint (which was not certified by peer review) is the author/funder, who has granted bioRxiv a license to display the preprint in perpetuity. It is made available under aCC-BY-NC-ND 4.0 International license.

Brock et al.

Next, we screened RVdG-infected RGCs for melanopsin expression by immunohistochemical detection of melanopsin on whole mount retinas and noted that none had the high levels of melanopsin expression typically associated with the M1 class; furthermore, dendritic morphologies did not resemble the stereotypical organisation characteristic of the M1 class (Fig. 2F; 261 cells, 12 retinas; $n=6$ mice). However, moderate to weak expression was often, but not always, observed in RVdG-labelled RGCs (Fig. 2F).
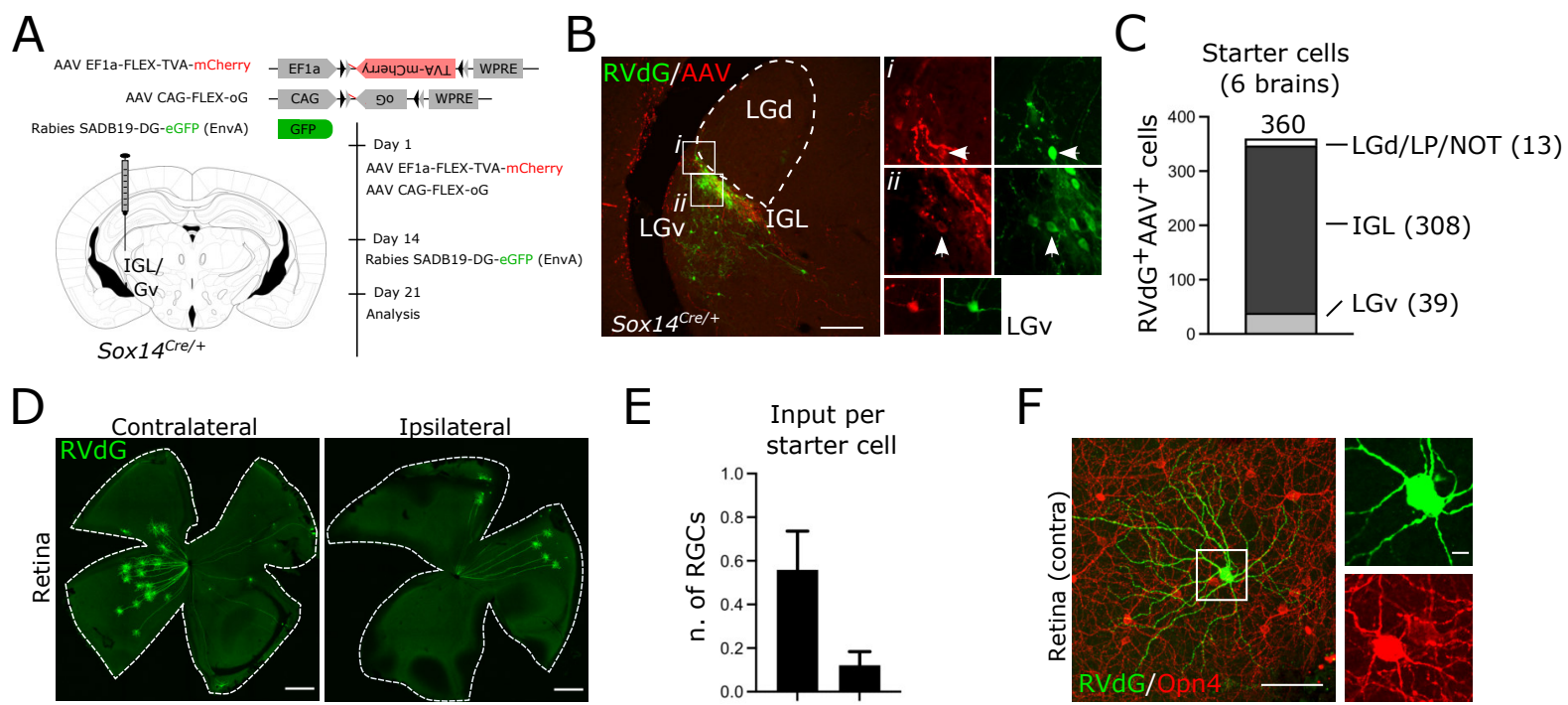

E
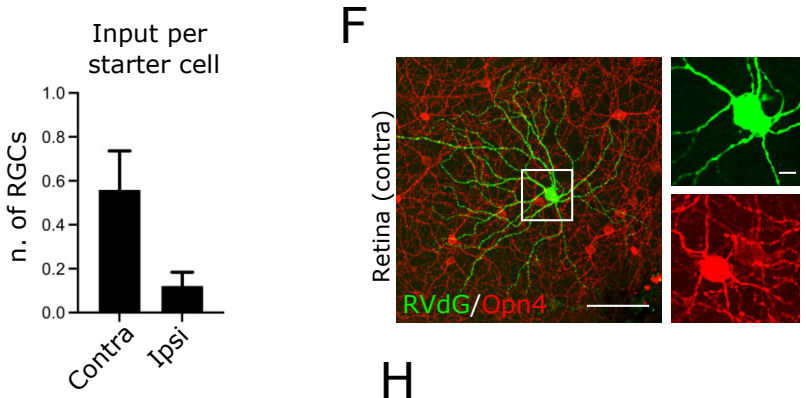

G

$\mathrm{H}$
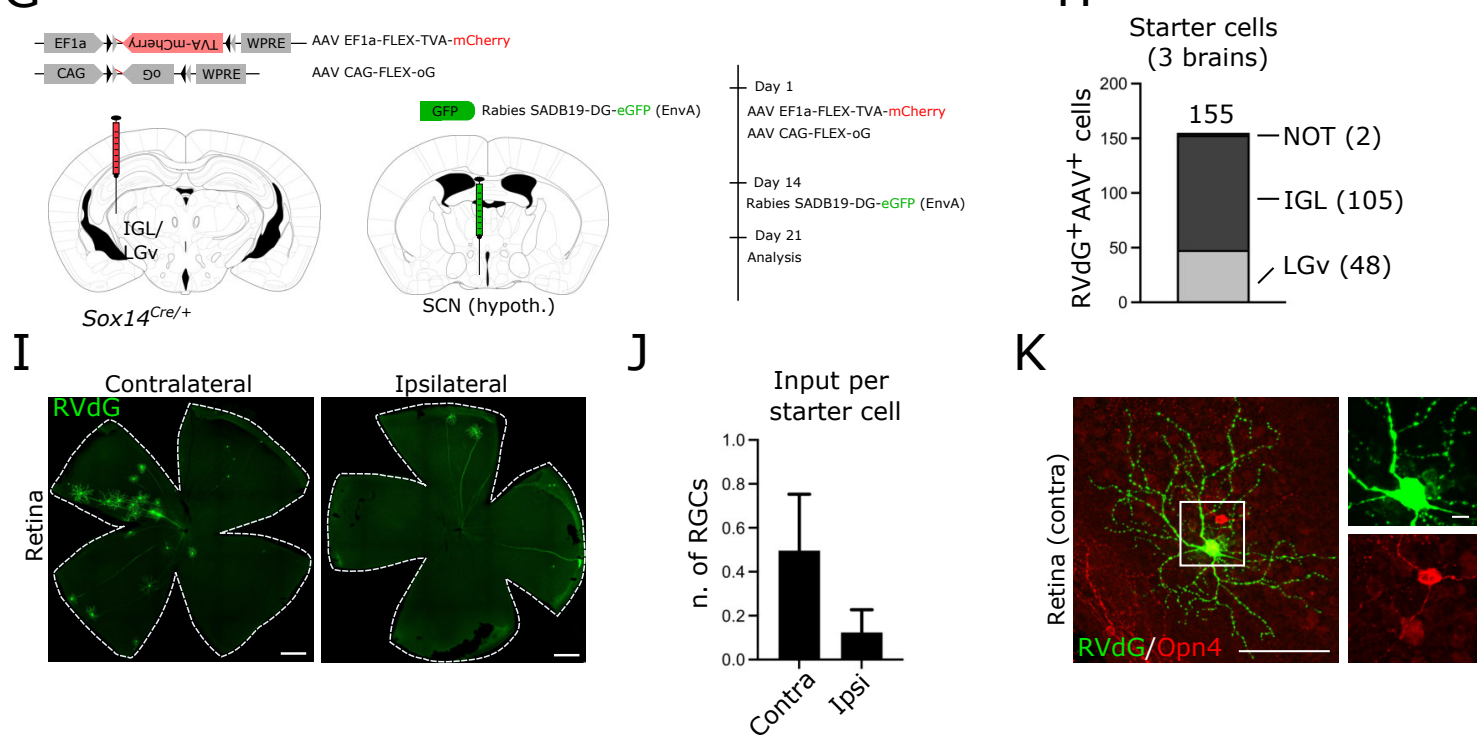

Figure 2.

Transsynaptic labelling of retinal input to Sox $14^{+}$neurons in the IGL/LGv. $\boldsymbol{A}$, scheme of rabies tracing of IGL/LGv input in Sox $14^{\mathrm{Cre} /+}$ line, showing the location and timeline of the injections and viral vectors used. $\boldsymbol{B}$, representative coronal section of virally encoded fluorophores at the injection site, showing RVdG (GFP, green) and helper AAVs (mCherry, red) double-positive neurons within the IGL (white arrowheads) and LGv. Scale bar: $100 \mu \mathrm{m}$. $C$, total count of primary infected cells in the target and off-target regions from serial confocal images 
bioRxiv preprint doi: https://doi.org/10.1101/2022.02.24.481804; this version posted February 25, 2022. The copyright holder for this preprint (which was not certified by peer review) is the author/funder, who has granted bioRxiv a license to display the preprint in perpetuity. It is made available under aCC-BY-NC-ND 4.0 International license.

Brock et al.

of all sections containing thalamic tissue ( $n=6$ mice). $D$, representative images of whole mount retinas showing the presence of RVdG-infected RGCs in the retinas ipsilateral and contralateral to the injected IGL/LGV. Scale bars are $500 \mu \mathrm{m}$. $\boldsymbol{E}$, the number of labelled RGCs per starter cell in the ipsi and contralateral retinas ( $n=6$ retina pairs). $\boldsymbol{F}$, example image of a retrogradely labelled RGC (green) with weak expression of melanopsin (Opn4, red) in its soma. Note the presence in the same field of view of other RGCs with much higher levels of melanopsin expression. Scale bars: overview image $100 \mu \mathrm{m}$, inset $10 \mu \mathrm{m}$. $\mathbf{G}$, scheme of rabies tracing of the input to the IGL/LGv subset with hypothalamic projections, showing the location and timeline of viral injections. $\boldsymbol{H}$, total count of primary infected cells in the target and off-target regions from serial confocal images of all sections containing thalamic tissue ( $n=3$ mice). $I$, representative images of whole mount retinas showing the presence of RVdG-infected RGCs in the retinas ipsilateral and contralateral to the injected IGL/LGv upon RVdG injection in the SCN region. Scale bars are $500 \mu \mathrm{m}$. J, the number of labelled RGCs per starter cell in the ipsi and contralateral retinas after the injection strategy in $\mathbf{G}(\mathrm{n}=3$ retina pairs). $\boldsymbol{K}$, example image of a retrogradely labelled RGC (green) with weak expression of melanopsin (Opn4, red) in its soma, after RVdG injection in the SCN region. Scale bars: overview image $100 \mu \mathrm{m}$, inset $10 \mu \mathrm{m}$.

The absence of any obvious M1 input to the Sox $14^{+}$IGL/LGV was unexpected, as

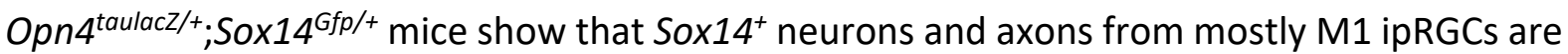
clearly present in that same area of the geniculate (Fig. 1M). Furthermore, numerous reports have hypothesised M1 specific innervation of the IGL/LGv (Chen et al., 2011; Ecker et al., 2010; Hattar et al., 2006). Although unlikely, there exist the possibility that our transsynaptic labelling of the RGCs is heavily skewed towards the small number of off target primary infected neurons detected in the LGd, LP and NOT (Fig. 2C), which could explain the absence of $\mathrm{M} 1$ input in favour of other melanopsin and non-melanopsin RGC subtypes known to project to thalamic visual areas. We therefore modified the RVdG labelling strategy by delivering the Cre-dependent AAVs in the IGL/LGv, but the RVdG in the ipsilateral SCN (Fig. 1G). While this viral delivery strategy did not result in the exclusive targeting of the SCN, the spread of the injected RVdG viral solution affected only the hypothalamic territory adjacent to the SCN. Hence, by injecting the RVdG in a well-known and distant target of the IGL/LGV we ruled out the possibility of detecting retinal input to the sparse Sox $14^{+}$interneurons of thalamocortical nuclei. This modified injection strategy reliably labelled hypothalamusprojecting Sox $14^{+} \mathrm{IGL} / \mathrm{LGv}$, as indicated by the cumulative total number of primary infected neurons from all thalamus-containing sections ( 3 mice) in the target region (Fig. $2 \mathrm{H}$; IGL: 105, 
bioRxiv preprint doi: https://doi.org/10.1101/2022.02.24.481804; this version posted February 25, 2022. The copyright holder for this preprint (which was not certified by peer review) is the author/funder, who has granted bioRxiv a license to display the preprint in perpetuity. It is made available under aCC-BY-NC-ND 4.0 International license.

Brock et al.

LGv: 48), with residual off target labelling observed in Sox $14^{+}$neurons in the NOT region (Fig.

$2 \mathrm{H} ; 2$ cells). RVdG infected RGCs were detected in all brains analysed (Fig. 2I), with the following normalised distribution: contralateral RGCs $0.50 \pm 0.26$ and ipsilateral RGCs $0.12 \pm$ 0.1 (Fig. 2J; mean \pm s.e.m, $n=3$ mice). Inspection of the retinas did not reveal any obvious $M 1$ dendritic morphology, nor was strong melanopsin expression seen in any of the RVdGinfected RGCs (Fig. 2K; 39 cells, $\mathrm{n}=3$ mice). This observation therefore reinforced our deduction that the thalamic component of the IGL/LGv, including neurons that project to the $\mathrm{SCN}$ area of the hypothalamus, lacks an obvious M1 input and suggests that this important source of luminance information may depend on a different and parallel Sox $14^{\text {neg }}$ IGL/LGV circuitry.

To confirm absence of M1 input and to further describe the morphological features of RVdGlabelled RGCs, we quantified radial dendritic morphology and dendritic stratification in the inner plexiform layer (IPL) relative to the $\mathrm{ChAT}^{+} \mathrm{ON}$ layer and the $\mathrm{ChAT}^{+}$OFF layer of amacrine cell processes (Sumbul et al., 2014) (Fig. 3A). The stratification of the IPL was divided in 10 layers (Rompani et al., 2017; Siegert et al., 2009) so that $\mathrm{ChAT}^{+} \mathrm{ON}$ and OFF layers match strata 7 and 3, respectively. A custom MATLAB script (kindly provided by Padraic Calpin, UCL) was used to bin the summed arbour density into each of these 10 strata and thresholding applied to colour-code densely populated bins (Fig. 3A; grey). We selected 40 RGCs from animals with AAVs and RVdG injected in the IGL/LGv (6 mice) and 12 RGCs from animals with AAVs injected in the IGL/LGV and RVdG injected in the hypothalamic SCN region (Fig. 3B; $n=$ 3 mice). Criterium for selection of the RGCs was their spatial segregation from other labelled RGCs, so that dendritic morphologies could be reliably reconstructed. We then grouped all reconstructed RGCs into three classes based on whether their dendritic stratification aligned with the ChAT ON lamina (ON), both the ChAT ON and OFF (ON-OFF) or the ChAT OFF lamina 
bioRxiv preprint doi: https://doi.org/10.1101/2022.02.24.481804; this version posted February 25, 2022. The copyright holder for this preprint (which was not certified by peer review) is the author/funder, who has granted bioRxiv a license to display the preprint in perpetuity. It is made available under aCC-BY-NC-ND 4.0 International license.

Brock et al.

(OFF; Fig. 3B,C); hence, the nomenclature adopted is not intended to reflect physiological properties, but dendritic stratification only. Plotting of the dendritic distribution in the IPL for the three groups clearly supports our initial observation of lack of M1 type input, as only 3 cells belonged to the OFF class, none of which was labelled by the hypothalamic injection of the RVdG (Fig. 3C). The ON group contained 21 RGCs, 17 labelled by injecting the RVdG in the IGL/LGv and 4 labelled by injecting it in the SCN hypothalamic region (Fig 3B,C). The ON-OFF group contained 28 RGCs, of which 8 were labelled by the SCN hypothalamic injection of the RVdG (Fig. 3B,C). While, the ON class displayed more homogenous dendritic stratification, the ON-OFF class appears clearly heterogeneous, with bistratified RGCs as well as RGCs showing broad dendritic density spanning the ChAT ON and OFF layers (Fig. 3C). To further characterise the types of RGCs in each of the three groups, we measured the diameter of the dendritic field, the total length of the dendritic tree and the number of dendritic branchpoints (Fig. D,E). We then performed Scholl analysis to measure dendritic complexity at increasing distances from the cell soma (Fig. 3F). We did not measure soma size, because of the heavily saturated GFP signal of the cell somas in our confocal images. RGCs in the ON group have dendritic features consistent with ON stratifying M2, M4 and M5 ipRGCs (Fig. 3D,E,G; range of branchpoints: $18-90$, range of dendritic tree diameter: $191.2-428.5$, range of total dendritic length: $2301-6821$ ) in line with other reports for these ipRGC subtypes (Berson et al., 2010; Ecker et al., 2010; Estevez et al., 2012; Schmidt and Kofuji, 2011; Stabio et al., 2018). Overall, RGCS in the ON-OFF group displayed broader morphological heterogeneity and significantly larger total dendritic length and branch points compared to the ON group (branch points: $p=0.0005$; total dendritic length: $p=0.012$; field diameter: $p=0.031$; KruskalWallis test). Stratification of the dendritic tree in the IPL discriminates M3 ipRGCs from similarly complex M2 dendrites (Schmidt and Kofuji, 2011). While some of the RGCs in this 
bioRxiv preprint doi: https://doi.org/10.1101/2022.02.24.481804; this version posted February 25, 2022. The copyright holder for this preprint (which was not certified by peer review) is the author/funder, who has granted bioRxiv a license to display the preprint in perpetuity. It is made available under aCC-BY-NC-ND 4.0 International license.

Brock et al.

group display parameters compatible with the M3 type, other RGCs display higher branch points and dendritic length compatible with the recently described M6 ipRGCs (Quattrochi et al., 2019).

A
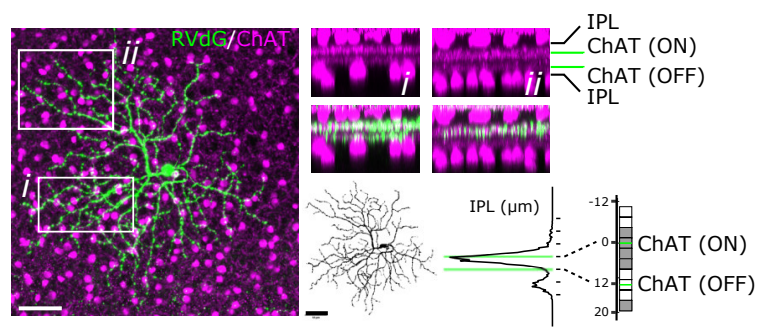

C

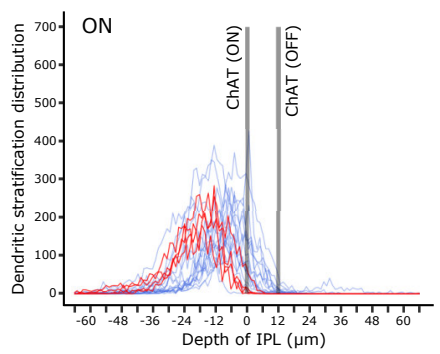

D
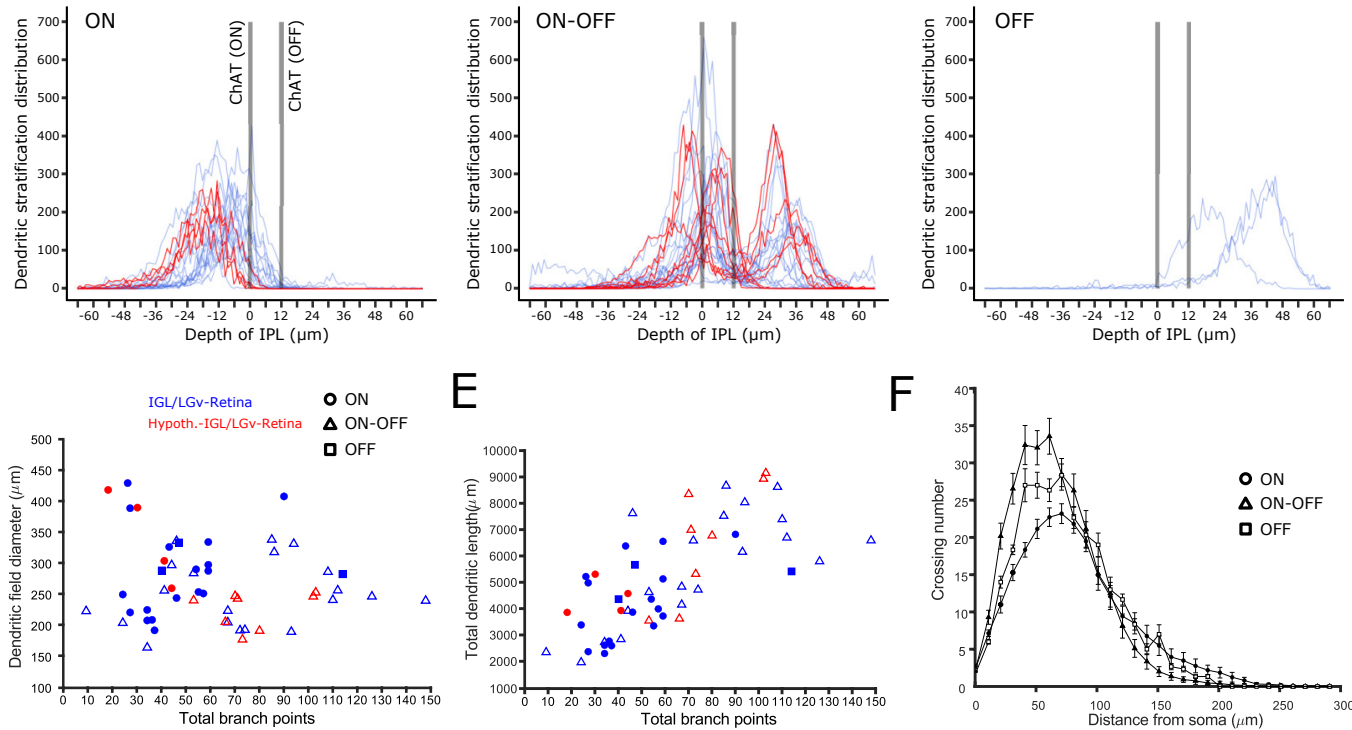

E
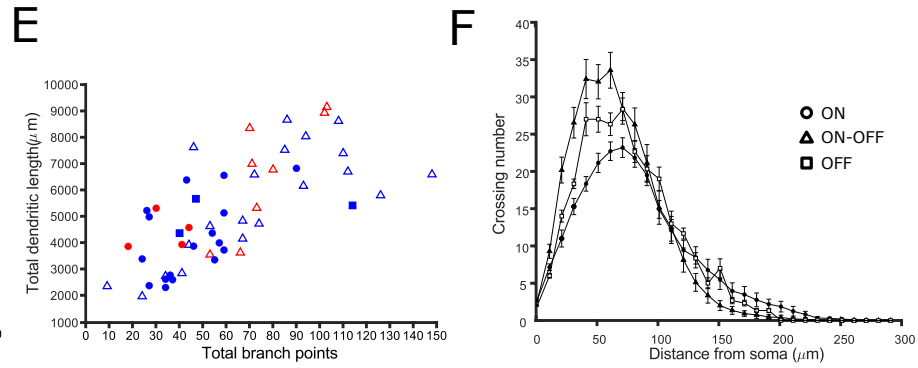

G

ON

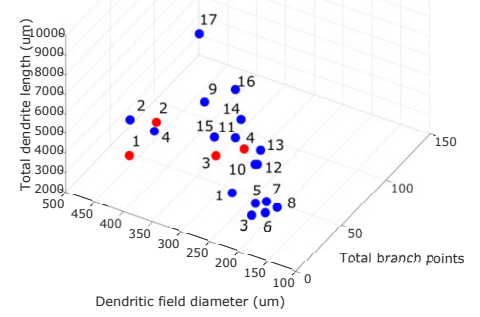

$\mathrm{H}$
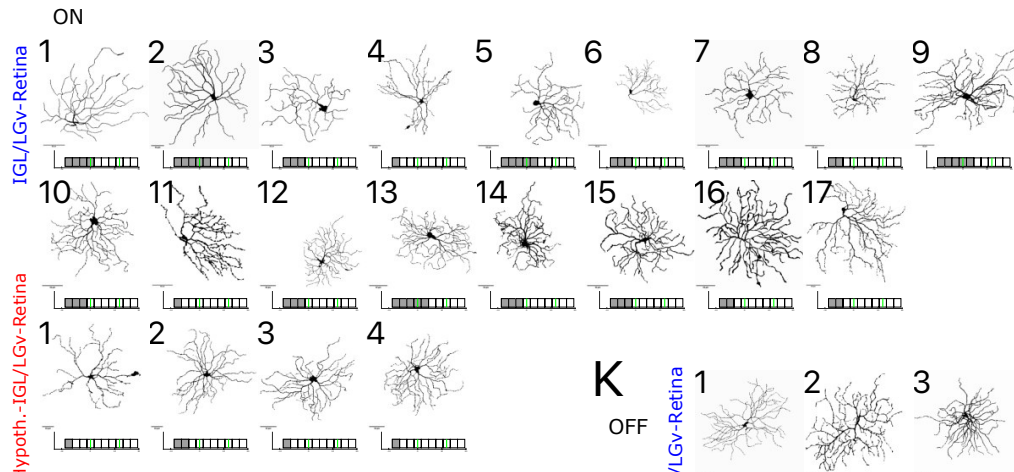

J

I
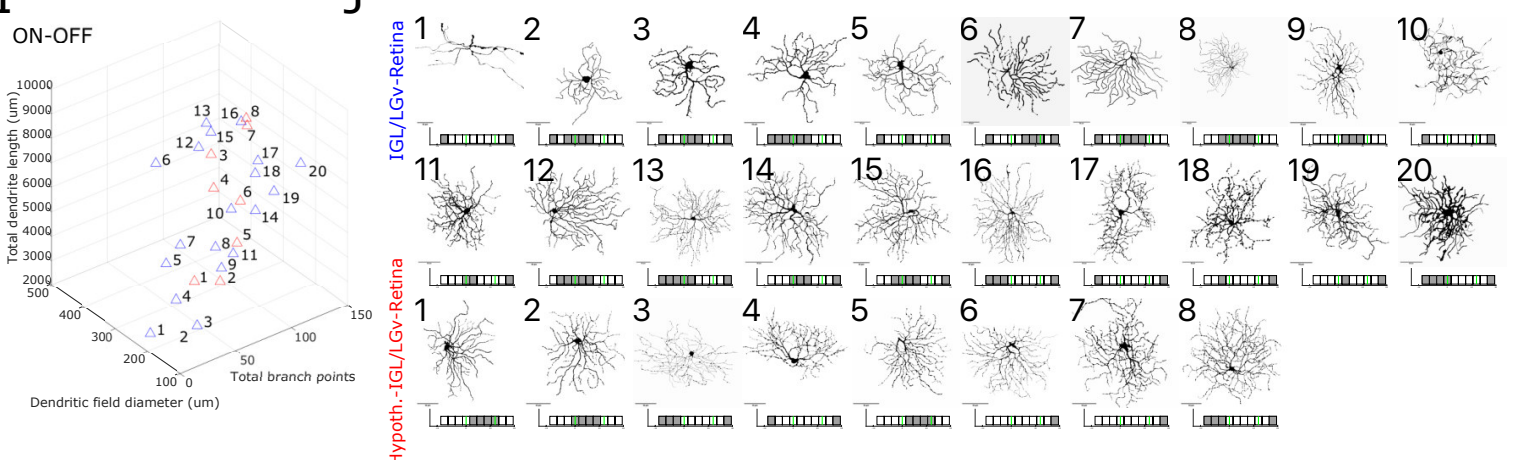
bioRxiv preprint doi: https://doi.org/10.1101/2022.02.24.481804; this version posted February 25, 2022. The copyright holder for this preprint (which was not certified by peer review) is the author/funder, who has granted bioRxiv a license to display the preprint in perpetuity. It is made available under aCC-BY-NC-ND 4.0 International license.

Brock et al.

\section{Figure 3.}

Dendritic morphology of RGCs projecting to Sox $14^{+}$neurons in the IGL/LGv. A, example images illustrating the strategy for the morphological analysis of RGC dendrites and their stratification in the IPL. The IPL is visualised sandwiched between $\mathrm{ChAT}^{+}$amacrine cell somas (magenta) for two arbitrary regions ( $i$ and ii) of an RVdG infected RGC (green). The dendritic reconstruction of the RGC is presented as black skeleton and the raw density of the GFP signal in the IPL is subdivided along 10 bins using grey colour for thresholding. Green lines represent $\mathrm{ChAT}^{+}$ON and OFF laminar references. Scale bars: $50 \mu \mathrm{m}$. B, morphological analysis was conducted for RGCs that did not have overlapping dendrites with other labelled RGCs. Graphical representation of the proportion of ON, ON-OFF and OFF stratifying RGCs, colour coded in blue when labelling occurred after RVdG injection in the IGL/LGv and in red when labelling occurred after RVdG injection in the hypothalamic region of the SCN (cumulative values from 9 mice). $\boldsymbol{C}$, distribution of dendritic densities for each of the 52 reconstructed RGCs, grouped according to their stratification in the ON and OFF laminas of the IPL and colour coded in blue or red as in $\mathbf{B}$. $\boldsymbol{D}, \boldsymbol{E}$, scatter plots displaying the dendritic field diameter and total dendritic length against the total dendritic branch points for all 52 reconstructed RGCs, colour coded in blue or red as in B. Filled circles represent the cells in the ON cluster, triangles the cells in the ON-OFF cluster and squares the cells in the OFF cluster. $\boldsymbol{F}$, Scholl analysis for the 3 clusters of RGCs, without colour coding to indicate location of the RVdG injection. G, 3D rendering of the morphological features in D,E for the ON RGC cluster, colour coded in blue or red according to the tracing strategy. $\boldsymbol{H}$, reconstructed dendritic trees and dendritic stratification profiles of retrogradely traced RGCs in the ON cluster, numbered according to their increasing branch points and divided according to the labelling strategy. Scale bars are $50 \mu \mathrm{m}$. I, 3D rendering of the morphological features in D,E for the ON-OFF RGC cluster, colour coded in blue or red according to the tracing strategy. $J$, reconstructed dendritic trees and dendritic stratification profiles of retrogradely traced RGCs in the ON-OFF cluster, numbered according to their increasing branch points and divided according to the labelling strategy. Scale bars are $50 \mu \mathrm{m}$. $\boldsymbol{K}$, reconstructed dendritic trees and dendritic stratification profiles of retrogradely traced RGCs in the OFF cluster which is only labelled by the RVdG injection in the IGL/LGv. Scale bars are $50 \mu \mathrm{m}$.

We cannot exclude that non-ipRGCs are also present in this group, for instance subsets of ONOFF direction selective (DS) RGCs. The LGv is one of the targets of ON-OFF DS-RGCs (Dhande et al., 2019; Huberman et al., 2009; Rivlin-Etzion et al., 2011) that could potentially mediate some of the non-image forming functions of this RGC class (Rivlin-Etzion et al., 2011).

In summary, reconstruction and quantitative analysis of dendritic morphologies of isolated RGCs retrogradely labelled from Sox $14^{+}$IGL/LGv neurons shows that OFF stratifying M1 ipRGCs are not an obvious source of luminance information (Fig. $3 \mathrm{C}, \mathrm{K}$ ), while heterogenous retinal input is mostly from ON (Fig. 3C,G,H) and ON-OFF ( Fig. 3C,I,J) stratifying RGCs. Several of the RGCs analysed here have morphological features compatible with non-M1 types of ipRGCs. However, we cannot exclude that other RGCs are also a source of retinal input to the Sox14+ IGL/LGv. 
bioRxiv preprint doi: https://doi.org/10.1101/2022.02.24.481804; this version posted February 25, 2022. The copyright holder for this preprint (which was not certified by peer review) is the author/funder, who has granted bioRxiv a license to display the preprint in perpetuity. It is made available under aCC-BY-NC-ND 4.0 International license.

Brock et al.

\section{Brain-wide input to the Sox $14^{+}$IGL/LGv is skewed towards visual networks}

The IGL/LGv is thought to receive and integrate photic information from the retina with information pertaining to the internal state of an organism, which ascends via the brainstem arousal system. Hence, we systematically analysed the range and proportion of afferents to the Sox $14^{+}$neurons of the IGL/LGv by mapping the location of all transsynaptic RVdG-infected cells $\left(\mathrm{GFP}^{+}\right)$in 4 of the 6 mice used for tracing of the retinal input (Fig. 2A). The vast majority of the afferents arise ipsilaterally in the diencephalic compartments: in the hypothalamus, the zona incerta (ZI) and LGv in the prethalamus, the IGL (including contralateral) and the pHB in the thalamus, the anterior pretectal nucleus (APN) and the nucleus of the optic tract (NOT) in the pretectum (Fig. 4A,B). More than half of the inputs can be grouped under a grossly visual functional classification that includes the retinorecipient subcortical visual shell (Table 4-1; including the superficial layers of the superior colliculus (SCs), the IGL/LGv, the olivary pretectal nucleus (ON) and the NOT), the cortical pyramidal neurons in layer 5 (L5) and 6b (L6b) of the primary visual area (VISp) (Fig. 4A,B) and direct retinal input (Fig. 2D).

In contrast, input from the ascending arousal system only accounted for less than $5 \%$ of the total (Fig. 4B,C,D,E and Table 4-1). Closer inspection revealed this input originates mostly in the serotonergic tryptophan hydroxylase (TPH) ${ }^{+}$dorsal Raphe (DR; Fig. 4C) and the cholinergic $\left(\mathrm{ChAT}^{+}\right.$) pedunculopontine nucleus (PPN; Fig. 4D). Although input from the locus coeruleus to the IGL has been proposed (Morin, 2013), we could not reliably detect it for the Sox14 subtype. Furthermore, we noted that not all the RVdG infected neurons in the PPN expressed the cholinergic marker ChAT (Fig. 4F; $72.5 \% \pm 16.01 \%$, mean \pm s.e.m.). Of the input arising in the DR, $65.7 \% \pm 7.68 \% \mathrm{GFP}^{+}$cells co-expressed the marker TPH (Fig. 4F; mean \pm s.e.m.). In the lateral hypothalamic area (LHA), a small fraction of the retrogradely labelled input was from orexinergic (OX) neurons (Fig. 4F; $27.06 \% \pm 13.0 \%$, mean \pm s.e.m.) and none was from 
bioRxiv preprint doi: https://doi.org/10.1101/2022.02.24.481804; this version posted February 25, 2022. The copyright holder for this preprint (which was not certified by peer review) is the author/funder, who has granted bioRxiv a license to display the preprint in perpetuity. It is made available under aCC-BY-NC-ND 4.0 International license.

Brock et al.

melanin concentrating hormone ( $\mathrm{MCH}$ ) neurons (Fig. 4E), in agreement to an earlier report in

hamsters (Vidal et al., 2005).
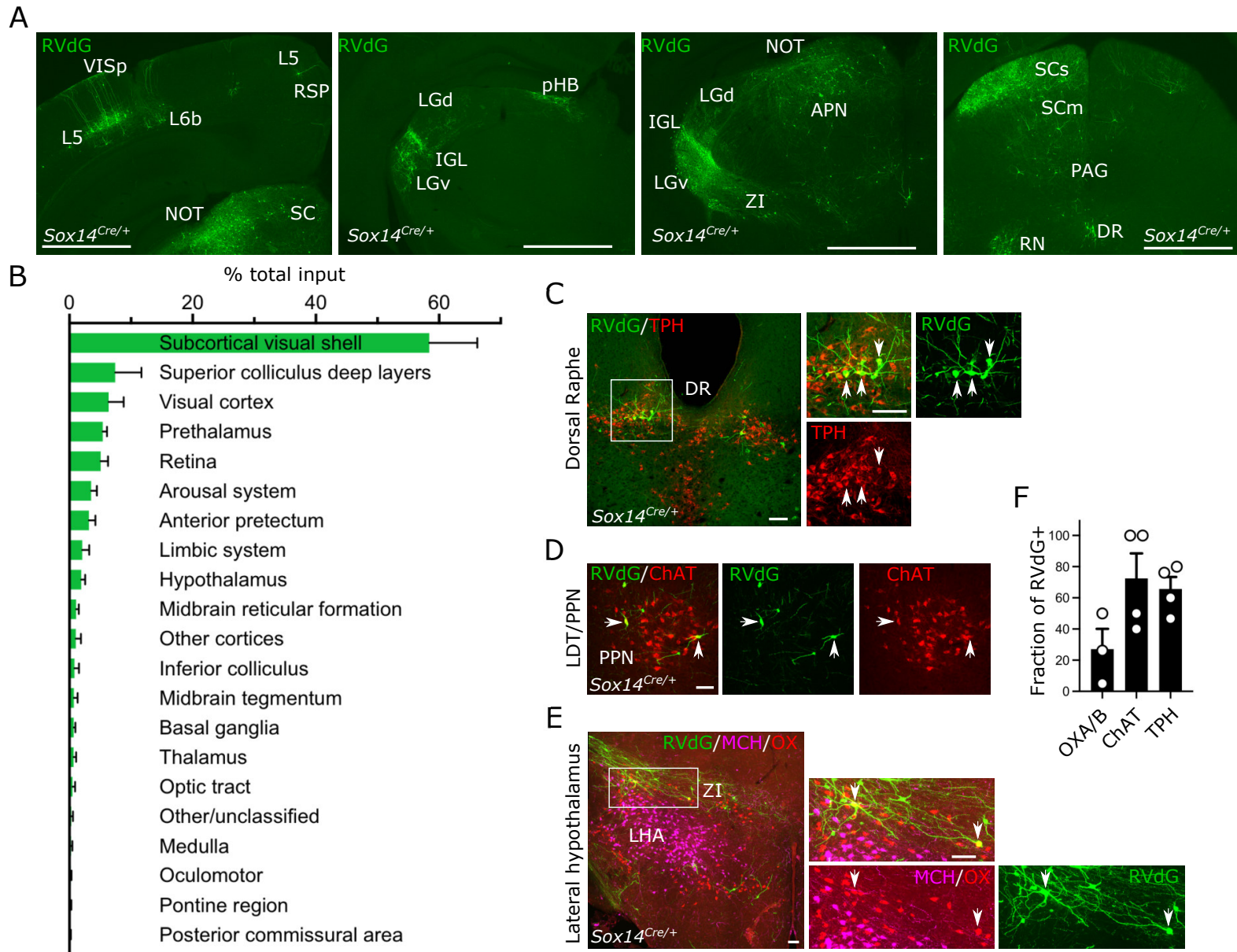

C

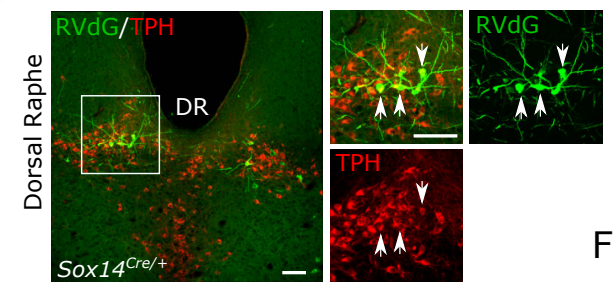

D
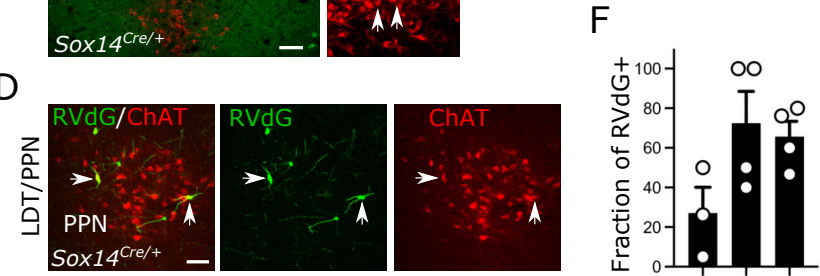

E
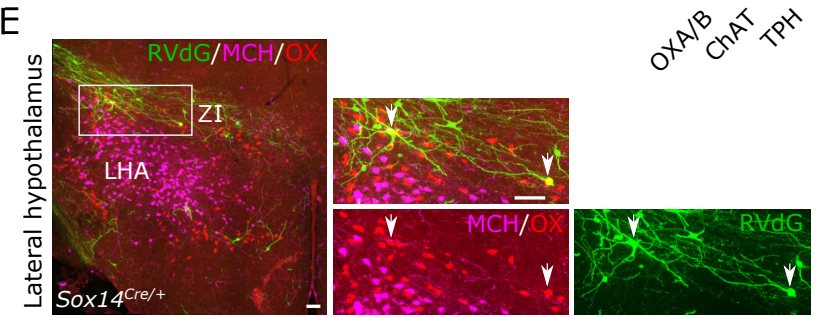

\section{Figure 4.}

Brain-wide input to the Sox $14^{+}$neurons in the IGL/LGV. $\boldsymbol{A}$, representative coronal sections showing brain-wide distribution of inputs to Sox $14^{+}$neurons in IGL/LGv. Most inputs to Sox14 $14^{+} \mathrm{IGL} / \mathrm{LGV}$ can be observed in areas with visual functions (VISp, SCs, NOT, IGL/LGv). Green, GFP from RVdG. Scale bars: $1 \mathrm{~mm}$. B, quantification of inputs to Sox $14^{+}$neurons in IGL/LGv, shown as percentage of total inputs (mean \pm s.e.m.; $\mathrm{n}=4$ mice). See also table 41 for anatomical classification based on (Franklin, 2001). C,D, representative coronal sections showing inputs from the ascending arousal system. Not all RVdG-infected cells (GFP+, green) are co-stained with the antitryptophan hydroxylase (TPH, red) antibody in dorsal raphe (DR) or the anti-choline acetyltransferase (ChAT, red) in pedunculopontine nucleus (PPN). Scale bars: $100 \mathrm{~mm}$. E, representative coronal section showing inputs from the lateral hypothalamus. In the lateral hypothalamic area, a small proportion of RVdG infected cells (GFP', green) are co-stained with the anti-orexinA/B antibody (OX, red), but none with the anti-melanin concentrating hormone antibody (MCH, magenta). Scale bars: $100 \mu \mathrm{m}$. $\boldsymbol{F}$, quantification of the fraction of RVdG labelled neurons that expressed the indicated markers (mean \pm s.e.m.).

In summary, the monosynaptic input to Sox $14^{+}$neurons in the IGL/LGv originates overwhelmingly from vision-related structures and to a limited extent from the brainstem's ascending arousal and neuromodulatory systems. 
bioRxiv preprint doi: https://doi.org/10.1101/2022.02.24.481804; this version posted February 25,2022 . The copyright holder for this preprint (which was not certified by peer review) is the author/funder, who has granted bioRxiv a license to display the preprint in perpetuity. It is made available under aCC-BY-NC-ND 4.0 International license.

Brock et al.

The Sox $14^{+}$IGL/LGv is required for circadian re-entrainment in presence of weak photic cues In mammals, alignment of circadian physiology and behaviour with the daily light cycle depends on rod, cones and melanopsin retinal photoreceptors and on specific ipRGC to brain connectivity so that free running circadian rhythms are observed only when all photoreceptors are simultaneously inactivated or ipRGCs selectively ablated (Guler et al., 2008; Hatori et al., 2008; Panda et al., 2003). Melanopsin loss of function mutations alone are not sufficient to cause an overt photoentrainment phenotype, but result in reduced pupillary constriction (Lucas et al., 2003) and reduced behavioural responses to acute light exposure (Altimus et al., 2008; Lupi et al., 2008; Mrosovsky and Hattar, 2003; Panda et al., 2002). The thalamic contribution to circadian photoentrainment is not fully elucidated. Our data showing the notable lack of M1 ipRGC input to the Sox $14^{+}$neurons of the IGL/LGV and limited innervation from the ascending arousal system represent unexpected findings that pose the question of the extent to which this developmentally defined subset of the IGL/LGv complex can contribute to circadian entrainment of motor activity rhythms.

We aimed to test the requirement of the IGL/LGV Sox $14^{+}$neurons in circadian photoentrainment under normal laboratory lighting conditions (200 lux) and under reduced luminance (10 lux) or photodetection (melanopsin loss of function). To achieve this, we

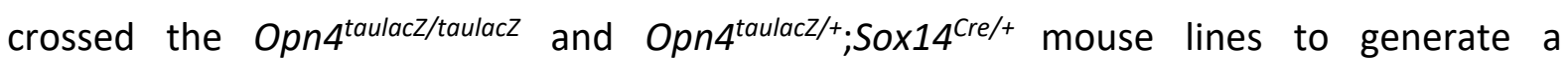
Opn $4^{\text {taulacz/+}}$;Sox $14^{\text {Cre/+ }}$ cohort with functional melanopsin expression and a Opn $4^{\text {taulacz/taulacz; }}$ Sox $14^{\text {Cre/t }}$ cohort lacking melanopsin expression. We then induced selective apoptosis of Sox14+ IGL/LGv neurons by injecting bilaterally in the IGL/LGv region an AAV that expresses the diphtheria toxin A subunit in a Cre-dependent manner and the fluorescent reporter mCherry constitutively (AAV2/1 Ef1a-mCherry-DIO-DTA; Fig. 5A). Control animals from both cohorts were injected with a Cre-dependent AAV vector expressing the fluorescent 
bioRxiv preprint doi: https://doi.org/10.1101/2022.02.24.481804; this version posted February 25, 2022. The copyright holder for this preprint (which was not certified by peer review) is the author/funder, who has granted bioRxiv a license to display the preprint in perpetuity. It is made available under aCC-BY-NC-ND 4.0 International license.

Brock et al.

reporter CFP (AAV2/1- Ef1a-DIO-CFP). The extent of ablation was estimated post hoc by mapping the spatial extent of fluorophore expression from the AAV vector (Fig. 5B). The successful ablation of Sox $14^{+}$neurons in the IGL/LGv was further confirmed by in situ hybridisation (ISH) with an RNA probe against the Npy mRNA (Fig. 5C; reduction in $\mathrm{Npy}^{+}$

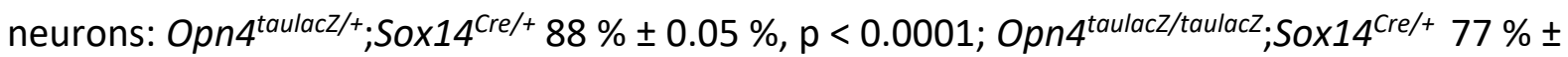
$0.14 \%, p=0.0003 ;$ mean \pm s.e.m.; unpaired t-test). DTA-ablated and control animals were single-housed in a circadian cabinet, and their spontaneous locomotor activity recorded via passive infrared detectors. Ablation of Sox $14^{+}$IGL/LGv neurons did not alter overall rhythmicity of motor behavior nor the circadian period length when animals were housed in constant darkness (tau; Fig. 5D); however a trend towards increased period upon IGL/LGv ablation was noted consistently with previous studies (Pickard, 1994). In both the melanopsin heterozygote (Fig. 5E,G) and knockout background (Fig. 5F,H), ablation of the Sox14+ IGL/LGV neurons did not affect the ability of the mice to photoentrain to standard laboratory light conditions (200 lux;12h light:12h dark; Fig. $5 \mathrm{I}, \mathrm{N}$ ).We then tested the ability of these animals to respond to a 6-hour phase advance in the light cycle, maintaining all other conditions, including luminance, unchanged. Fourteen days after the light phase advance, all groups had entrained to the new light cycle (Fig. 5I,O), indicating that neither the Sox $14^{+}$IGL/LGv neurons nor melanopsin expression or both combined are required for circadian resetting of activity rhythms under standard luminance (200 lux). However, ablation of the Sox $14^{+}$IGL/LGV appeared to cause a delayed behavioural response to the light phase advance (Fig. 5I), which did not reach statistical significance after correction for multiple comparisons (Fig. 50; minutes to re-entrainment at day 7: Opn4taulacz/+ Sox 14 -control $11.25 \pm 11.25$ minutes

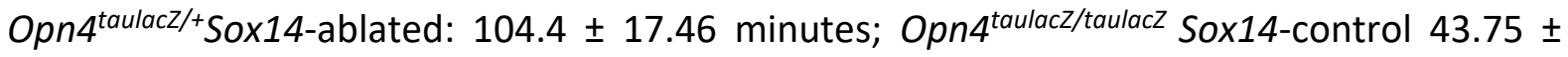
25.77 Opn4 $4^{\text {taulacz/taulacz }}$ Sox 14 -ablated $119.2 \pm 42.43$ minutes; mean \pm s.e.m.). This observation 
bioRxiv preprint doi: https://doi.org/10.1101/2022.02 24.481804; this version posted February 25,2022 . The copyright holder for this preprint (which was not certified by peer review) is the author/funder, who has granted bioRxiv a license to display the preprint in perpetuity. It is made available under aCC-BY-NC-ND 4.0 International license.

Brock et al.

of delayed entrainment under standard light conditions is consistent with earlier neurotoxin injections in the lateral geniculate of the hamster (Johnson et al., 1989).
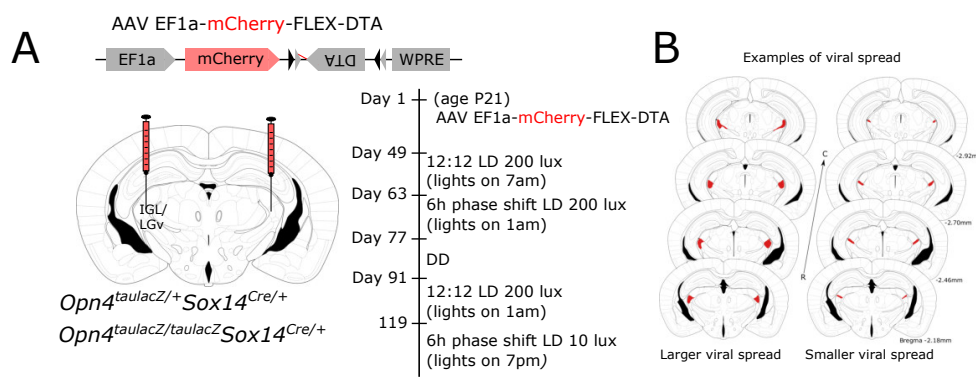

E

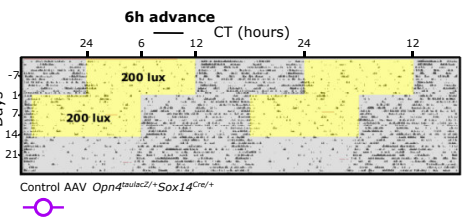

$\mathrm{F}$

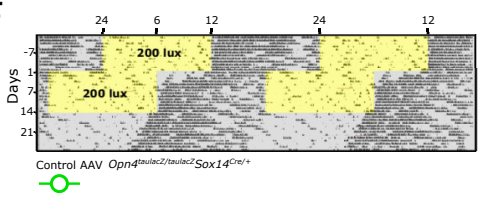

]

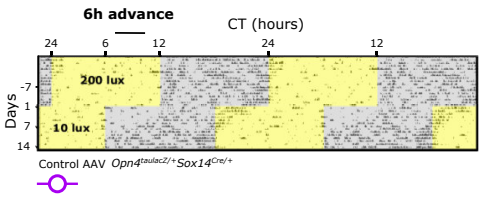

$\mathrm{K}$

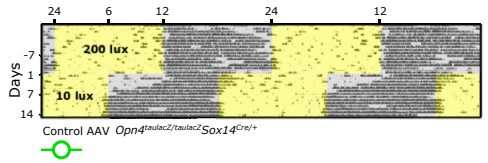

$\mathrm{O}$

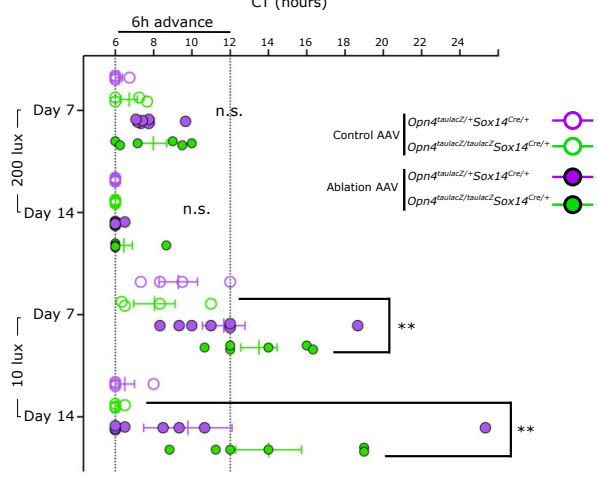

$\mathrm{S}$

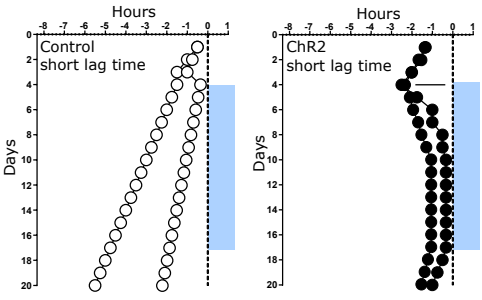

L

M

$\mathrm{P}$

Q

T

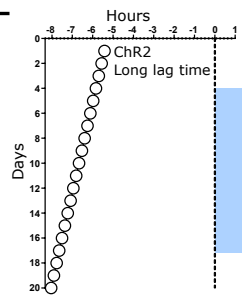

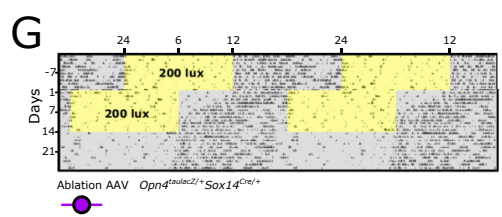
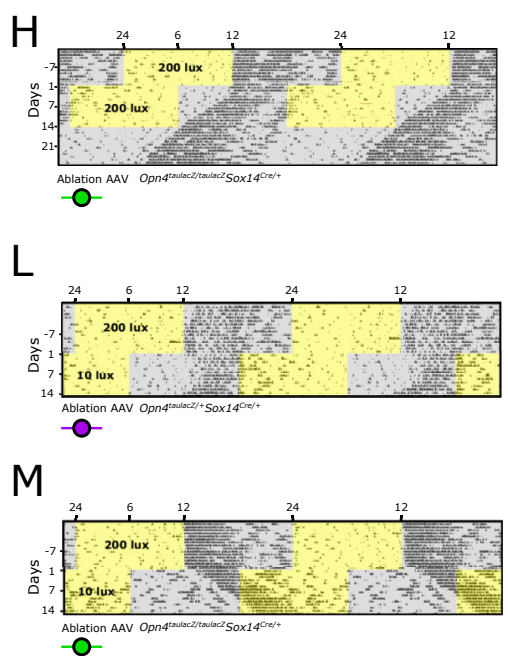

_EF1a AAV EF1a-ChR2-mCherry
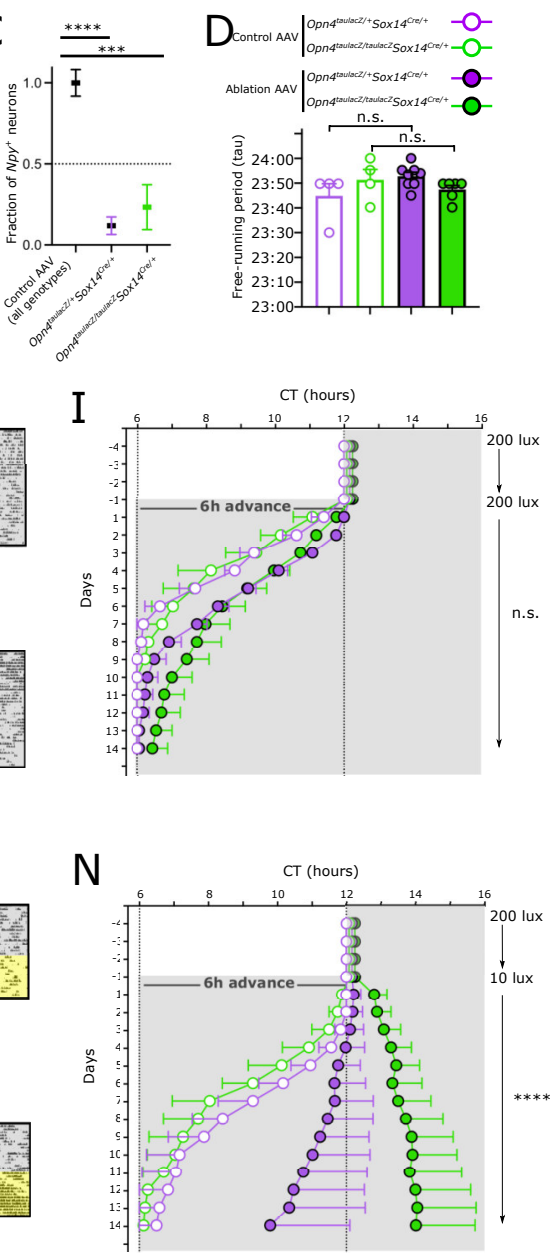

$-12 \mathrm{~h}$
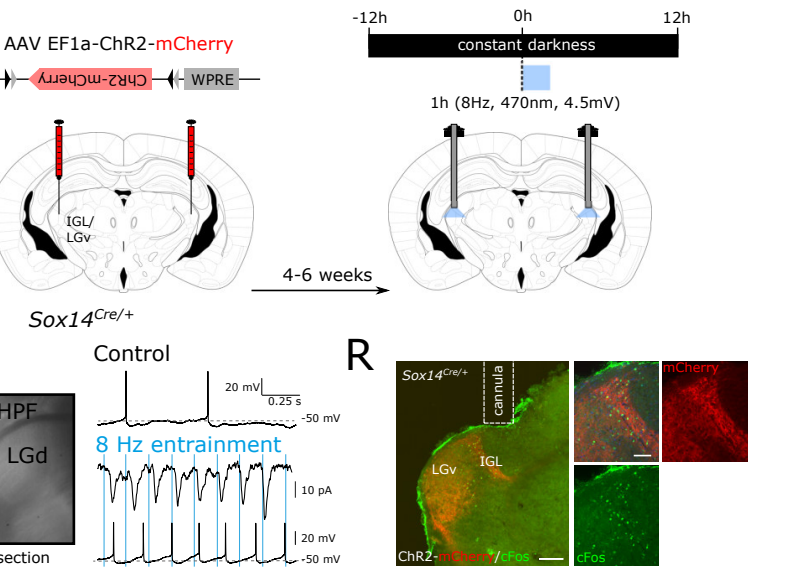

$\mathrm{R}$

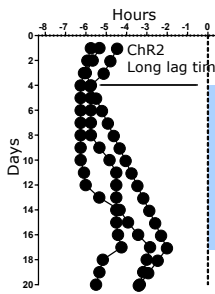

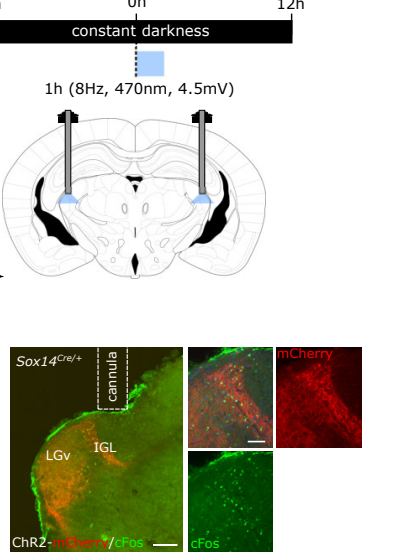

$1 \mathrm{~h}(8 \mathrm{~Hz}, 470 \mathrm{~nm}, 4.5 \mathrm{mV})$
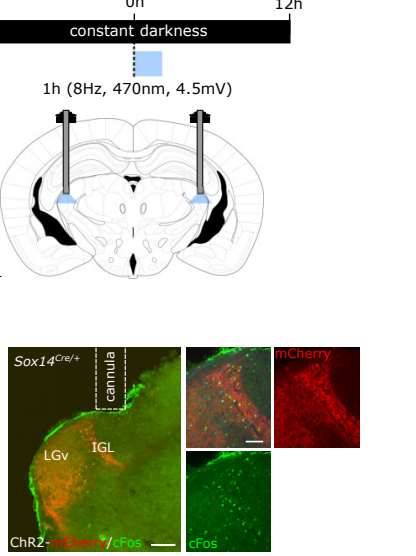

U

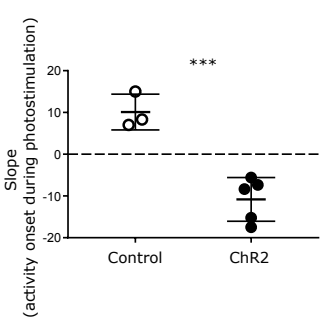


bioRxiv preprint doi: https://doi.org/10.1101/2022.02.24.481804; this version posted February 25, 2022. The copyright holder for this preprint (which was not certified by peer review) is the author/funder, who has granted bioRxiv a license to display the preprint in perpetuity. It is made available under aCC-BY-NC-ND 4.0 International license.

Brock et al.

\section{Figure 5.}

Perturbation of the Sox $14^{+}$IGL/LGv neurons leads to aberrant onset of circadian motor activity rhythms. $\boldsymbol{A}$, scheme for the specific ablation of Sox $14^{+}$IGL/LGv neurons in the melanopsin loss of function and control background and timeline of the circadian light paradigms. B, Evaluation of the viral spread upon stereotaxic injection in the IGL/LGv region, in two representative brains depicting the extent of mCherry expression (red), which is not Cre-dependent, in a case of more extensive viral infection (left) and one of less extensive infection (right). $\mathrm{C}$, quantification of the residual fraction of IGL Npy+ cells, setting the mean value for non-ablated samples

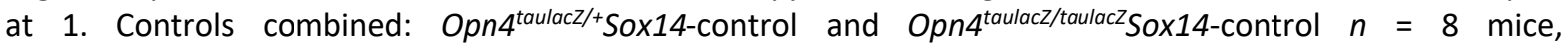
Opn $4^{\text {taulacz/+ }}$ Sox14-ablated $n=7$ mice, Opn4 ${ }^{\text {taulacz/taulacz }}$ Sox14-ablated $n=5$ mice. One way ANOVA F(32.53). p < 0.0001 ; mean \pm s.e.m. ${ }^{* * * *}<0.0001 ; * * *=0.0003$; t-test. $D$, Similar period length under constant dark conditions for all animals in the four groups (n.s.; ANOVA). $\boldsymbol{E}, \boldsymbol{F}, \boldsymbol{G}, \boldsymbol{H}$, actograms for a representative mouse per group illustrating the activity rhythms under 200 lux, after a 6 hours phase advance and in constant darkness. Period of lights on are in yellow, periods of lights off are in grey. I, onset of circadian motor activity for the four groups, colour coded as in D. Periods of lights off are in grey. Days 1 to 14: n.s.; ANOVA. Data plotted as mean \pm s.e.m. $\mathbf{J}, \boldsymbol{K}, \mathbf{L}, \mathbf{M}$, actograms for the same representative mice as in $\mathbf{E}, \mathbf{F}, \mathbf{G}, \mathbf{H}$ illustrating the activity rhythms under 200 lux, after a 6 hours phase advance with concomitant reduction of ambient luminance to 10 lux. $\boldsymbol{N}$, onset of circadian motor activity for the four groups. Periods of lights off are in grey. Days 1 to 14: $p<0.0001 ;$ Kruskal-

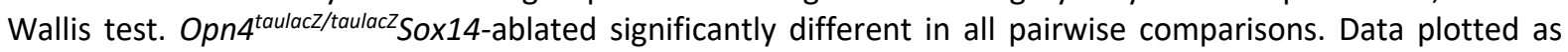
mean \pm s.e.m.. $\boldsymbol{O}$, onset of circadian activity rhythms for each animal in the four groups at day 7 and day 14 after the 6 hours phase advance in the light cycle either in standard luminance (200 lux) or dim luminance (10 lux). At 200 lux, a trend towards delayed circadian onset of activity was detected at day 7 however this was not statistically significant ( $p=0.041$; Kruskal-Wallis test. N.s. after multiple comparison correction). At 10 lux, a high degree of interindividual variability was observed at day 7 and day 14 in the onset of circadian activity rhythms for both the Opn4 ${ }^{\text {taulacz/+}}$ Sox14-ablated and the Opn $4^{\text {taulacz/taulacz }}$ Sox14-ablated groups, which included cases of period lengthening and irregular patterns of activity onset (Day 7: $F(4.294), p=0.019$, ANOVA; Tukey's multiple comparisons test $p=0.021$ for the Opn $4^{\text {taulacz/taulacz }}$ Sox14-ablated group. Day 14: $p=0.0082$ Kruskal-Wallis test; Dunn's multiple comparisons test $p=0.021$ for the Opn4taulacz/taulaczSox14-ablated group versus Opn4 $4^{\text {taulacz/taulacz }}$ Sox14-control group and $p=0.028$ for the Opn4 $4^{\text {taulacz/taulacz }}$ Sox14-ablated group versus Opn $4^{\text {taulacz/+ }}$ Sox14-control group. Data plotted as mean \pm s.e.m.. $P$, schematic strategy for the expression of ChR2 in Sox $14^{+}$IGL/LGv neurons and the circadian optogenetic stimulation (blue line, $1 \mathrm{~h} / \mathrm{day}, 470 \mathrm{~nm}, 8 \mathrm{~Hz}$ ). $Q$, a bright-field image of the acute slice preparation indicating the location (asterisk) of whole-cell recordings from $\mathrm{mCherry}$ expressing neurons within the IGL/LGv. The top voltage trace was obtained from a single neuron in the IGL/LGv showing spontaneous AP generation in the absence of blue light stimuli. The middle trace shows the ChR2-mediated currents elicited by blue light stimulation and the bottom voltage trace demonstrates the resulting entrainment of APs at $8 \mathrm{~Hz}$ optogenetic stimulation. $\boldsymbol{R}$, representative images from an injected Sox $14^{\text {Cre/t+ }}$ mouse showing the location of virally infected cells (mCherry, red) in the IGL/LGv region and optogenetically induced c-Fos expression (green), $90 \mathrm{~min}$ after the end of the stimulation. Scale bars: $100 \mu \mathrm{m}$. $S$, daily onset of circadian activity in two control subjects (white circle, left graph) and two subjects expressing ChR2 within Sox14+ IGL/LGv neurons (black circles, right panel), housed under constant dark conditions. Onset of optogenetic stimulation occurred within the first 3 hours of the subjective night. $T$, daily onset of circadian activity in one control subject (white circle, left graph) and three subjects expressing ChR2 within Sox14+ IGL/LGV neurons (black circles, right panel), housed under constant dark conditions. Onset of optogenetic stimulation occurred approximately 6 hours into the subjective night. $\boldsymbol{U}$, plot showing the slope of activity onset over 14 days of optogenetic stimulation in control and ChR2-expressing mice. Positive values indicate negative drifting typical of free running rhythms under constant darkness, whereas negative values reflect a switch to positive drifting. Control group: $10.11 \pm 2.48$, ChR2-expressing group: $-11.38 \pm 1.58, p=0.0002$; mean \pm s.e.m.; t-test.

We subsequently tested the ability of control and ablated mice to entrain to a further 6-hour phase shift while simultaneously reducing the strength of the light zeitgeber to 10 lux; Fig. $5 J, K, L, M, N)$. Luminance of 10 lux and below mimics the ecologically relevant twilight 
bioRxiv preprint doi: https://doi.org/10.1101/2022.02 24.481804 t this version posted February 25,2022 . The copyright holder for this preprint (which was not certified by peer review) is the author/funder, who has granted bioRxiv a license to display the preprint in perpetuity. It is made available under aCC-BY-NC-ND 4.0 International license.

Brock et al.

conditions and suffice to generate SCN activation and behavioural photoentrainment in laboratory mice (Cheng et al., 2004).

Regardless of the status of Opn4 expression, by day 14 after the dim-light phase advance all but two of the animals that did not experience ablation of Sox $14^{+}$IGL/LGv neurons had successfully entrained their activity rhythms to the new dim light cycle (Fig. 50; minutes to

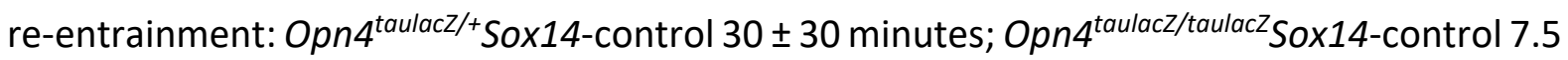
\pm 7.5 minutes, mean \pm s.e.m.). Ablation of Sox $14^{+}$IGL/LGv impacted the ability of the animals to rapidly entrain to the new dim light cycle (Fig. $5 \mathrm{~N} ; \mathrm{p}<0.0001$ Kruskal Wallis test).

Ablation of the Sox $14^{+}$IGL/LGv had a differential effect on re-entrainment to the dim light cycle depending on the status of Opn4 expression (Fig. 5J,K,L,M). By day 14 from the dim light phase advance, only 3 out of 8 mice in the Opn $4^{\text {taulacz/+}}$ Sox 14 -ablated group had entrained to the new light cycle and one animal displayed a lengthening of the circadian period (positive drifting; Fig. 50). Furthermore, we observed irregular patters of activity onset (Fig. 5L) during the 14 day-period, which were not present in the same animals exposed to the jet lag paradigm at 200lux. Contrary to the result observed under 200 lux, under dim light the melanopsin loss of function accentuated the entrainment phenotype observed upon ablation of the Sox14+ IGL/LGV (Fig. $5 \mathrm{~N}$ ) so that by day 14, none of the animals in the

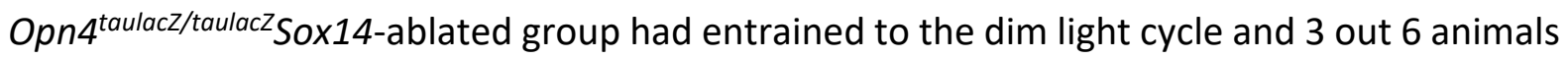
displayed period lengthening (Fig. $5 \mathrm{M}, \mathrm{N}, \mathrm{O}$; minutes to re-entrainment at day 7 : Opn4 ${ }^{\text {taulacz/taulacz }}$ Sox14-control $122.5 \pm 65.11$ minutes, Opn4 $4^{\text {taulacz/taulacz }}$ Sox14-ablated: $450.0 \pm$ 56.98 minutes, $p=0.0058$, mean \pm s.e.m, unpaired t-test; minutes to re-entrainment at day 14: Opn4 $4^{\text {taulacz/taulacz }}$ Sox14-control $7.5 \pm 7.5$ minutes, Opn4 $4^{\text {taulacz/taulacz }}$ Sox 14 -ablated $480.8 \pm$ 102.9 minutes, mean \pm s.e.m., $p=0.0095$, Mann-Whitney test). 
bioRxiv preprint doi: https://doi.org/10.1101/2022.02 24.481804 t this version posted February 25,2022 . The copyright holder for this preprint (which was not certified by peer review) is the author/funder, who has granted bioRxiv a license to display the preprint in perpetuity. It is made available under aCC-BY-NC-ND 4.0 International license.

Brock et al.

Taken together, these data showed that while neither melanopsin expression nor the Sox $14^{+}$ neurons of the IGL/LGv are required for entrainment and re-entrainment in a jet-lag paradigm, the Sox $14^{+} \mathrm{IGL} / \mathrm{LGv}$ neurons contribute to the rapid resetting of circadian activity rhythms. Strikingly, while under luminance levels akin to twilight conditions melanopsin loss of function alone had little effect on the ability of the mice to photoentrain, the combined ablation of the Sox $14^{+}$IGL/LGv severely disrupted circadian photoentrainment of activity rhythms.

\section{Daily optogenetic stimulation of the Sox $14^{+}$IGL/LGv neurons entrains motor activity rhythms}

Circadian rhythms of nocturnal animals can be entrained by pulses of light given at dusk and dawn, possibly reflective of the light sampling behaviour displayed in their natural ecological niche (DeCoursey, 1986; Edelstein and Amir, 1999; Rosenwasser et al., 1983b; Stephan, 1983b). Consistent with those earlier studies, optogenetics-assisted resetting of circadian oscillatory activity in dark reared mice can be achieved by daily, 1 hour-long, blue light pulses delivered at low frequency $(4-8 \mathrm{~Hz}$ ) on SCN neurons expressing ChR2 (Jones et al., 2015; Mazuski et al., 2018).

To investigate whether experimental activation of Sox14 ${ }^{+}$IGL/LGv neurons is also sufficient to alter circadian patterns of behaviour, we aimed to replicate this artificial circadian entrainment protocol, stimulating the Sox $14^{+}$IGL/LGv neurons instead of the SCN ones. To achieve this, we injected either a Cre-dependent AAV vector expressing the light-gated ion channel Channelrodopsin2 (ChR2; AAV2/5 Ef1a-DIO-hChR2(H134R)-mCherry) or a control AAV expressing the cyan fluorescent protein (AAV2/1- Ef1a-DIO-CFP; Fig. 5P) bilaterally in the IGL/LGv region of Sox $14^{\mathrm{Cre} /{ }^{+}}$mice. We then tested the impact of forced ChR2-mediated 
bioRxiv preprint doi: https://doi.org/10.1101/2022.02.24.481804; this version posted February 25,2022 . The copyright holder for this preprint (which was not certified by peer review) is the author/funder, who has granted bioRxiv a license to display the preprint in perpetuity. It is made available under aCC-BY-NC-ND 4.0 International license.

Brock et al.

activation of the Sox $14^{+}$IGL/LGv neurons for 1 hour at daily intervals on the onset of circadian locomotor activity in animals housed under constant darkness (Fig. 5P).

Pulses of blue light (470nm) were delivered bilaterally directly above the IGL/LGv at a frequency of $8 \mathrm{~Hz}$ (Fig. 5P), which falls within the physiological frequency range of IGL neurons (Chrobok et al., 2021; Chrobok et al., 2018; Lewandowski and Blasiak, 2004) and of the SCN neurons during the light phase of the day (Jones et al., 2015; Sakai, 2014). Furthermore, optogenetic $10 \mathrm{~Hz}$ stimulation of RGC axon terminals is sufficient to activate IGL neurons (Shi et al., 2020).

Ex vivo patch clamp recording from ChR2-expressing IGL neurons confirmed reliable lightinduced responses to $8 \mathrm{~Hz}$ blue light entrainment (Fig. 5Q). In vivo, this optogenetic protocol led to expression of the immediate early gene c-Fos in the IGL/LGv (Fig. 5R), which is a reliable marker of neuronal activation (Dragunow and Faull, 1989; Peters et al., 1996).

As expected, housing under constant dark conditions efficiently induced free running rhythms in control and experimental mice (Fig. 5S,T,U; white and black circles, respectively). However, while daily optogenetic light stimulation in control animals had no significant impact on the onset of circadian motor activity (Fig. 5S,T; white circles), it affected it profoundly in experimental animals that expressed ChR2 (Fig. 5S,T; black circles). The impact of daily stimulation of the Sox $14^{+}$IGL/LGv is reflected in the drastic change in the slope of the circadian onset of motor activity between the two groups (Fig. $5 \mathrm{U} ; \mathrm{p}=0.0002$; t-test).

The gradual shift of the activity onset, which moved progressively towards the time of stimulation and in some but not all cases, locked onto it, is strikingly similar to the results obtained when stimulation was applied directly onto the SCN (Jones et al., 2015; Mazuski et al., 2018). Acute light pulses during the active phase in nocturnal animals caused negative masking of motor activity (Morin and Studholme, 2014a; Mrosovsky et al., 2001; Redlin, 
bioRxiv preprint doi: https://doi.org/10.1101/2022.02 24.481804 t this version posted February 25,2022 . The copyright holder for this preprint (which was not certified by peer review) is the author/funder, who has granted bioRxiv a license to display the preprint in perpetuity. It is made available under aCC-BY-NC-ND 4.0 International license.

Brock et al.

2001), a response that has recently been suggested to depend on IGL neurons (Shi et al., 2020). In our experimental conditions, a reduction in spontaneous motor activity was detected during the first episode of optogenetic stimulation of the Sox $14^{+}$IGL/LGv neurons (motor activity change during optogenetic stimulation compared to hour following it ChR2 group: $38.51 \% \pm 19.72 \%$; CFP group: $391.4 \% \pm 123.0 \%$, mean \pm s.e.m., $p=0.0093$; t-test); however the decrease in motor activity was negligeable over seven consecutive days of optical stimulation (ChR2 group: $141.0 \% \pm 13.76 \%$; CFP group: $229.8 \% \pm 37.48 \%$, mean \pm s.e.m., $p=0.036$; t-test).

The effect of the optogenetic stimulation of the Sox14+ IGL/LGv neurons on the phase of circadian motor activity was observed regardless of the lag time between the endogenous onset of locomotor activity and the time of the optogenetic stimulation (Fig. 5S, short lag time and Fig. 5T, long lag time). This optogenetically-induced effect on the onset of circadian motor activity is rapidly reversed upon termination of the photostimulation (Fig. 5S,T). Hence, in absence of a strong zeitgeber such as circadian light, daily optogenetic stimulation of the Sox $14^{+}$neurons of the IGL/LGv is sufficient to reorganise circadian locomotor activity.

\section{The Sox $14^{+}$IGL/LGv neurons are required for rapid change in vigilance states at circadian}

\section{light transitions}

Circadian transitions between light and dark regulate neuronal network dynamics that contribute to shaping the sleep-wake cycle. We hypothesised that the broad innervation of the Sox $14^{+}$neurons in the IGL/LGv by visual networks may reflect an underappreciated role in regulating rapid changes in vigilance in response to circadian light transitions. Such brain network changes may not be readily detected by monitoring gross circadian locomotor 
bioRxiv preprint doi: https://doi.org/10.1101/2022.02.24.481804; this version posted February 25, 2022. The copyright holder for this preprint (which was not certified by peer review) is the author/funder, who has granted bioRxiv a license to display the preprint in perpetuity. It is made available under aCC-BY-NC-ND 4.0 International license.

Brock et al.

activity but can be more reliably measured as changes in the spectral power of a cortical electroencephalogram (EEG).

A
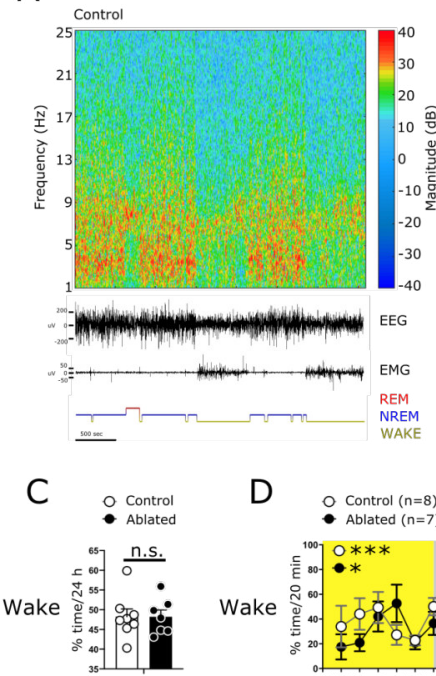

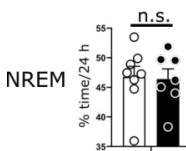

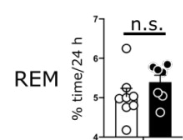

B

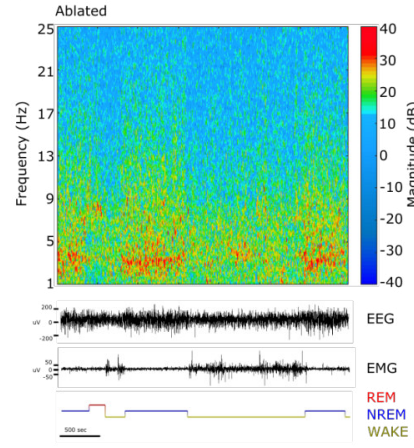

$\mathrm{E}$
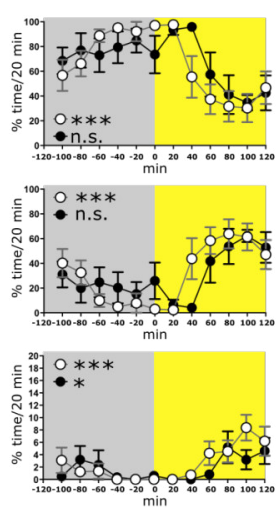

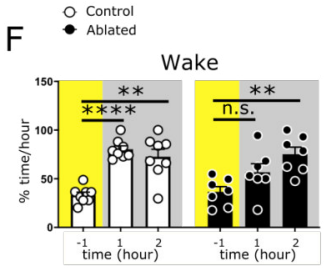

NREM

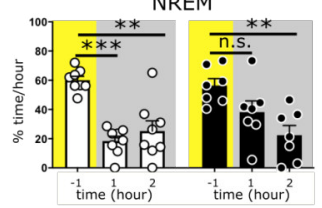

REM
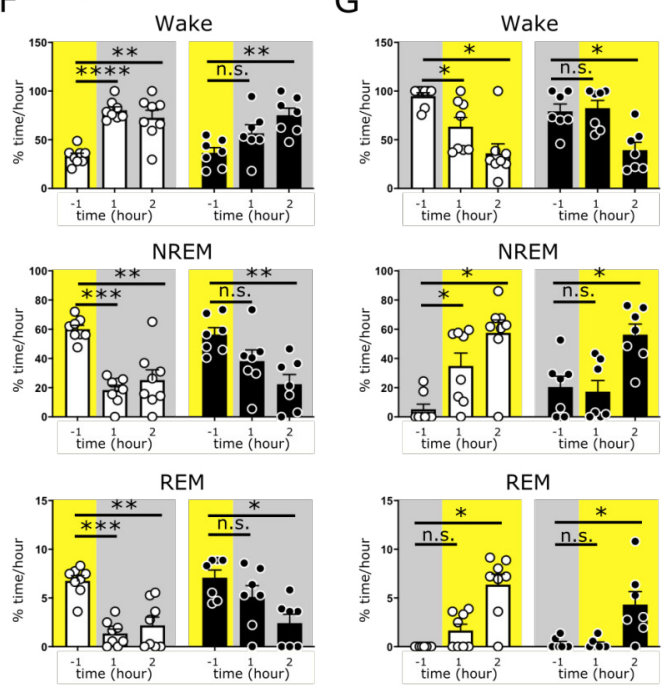

NREM

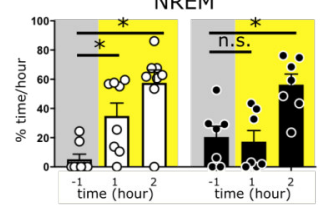

REM

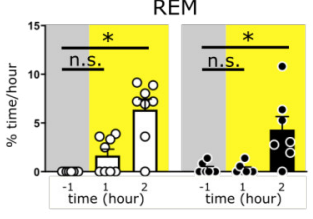

$\mathrm{H}$
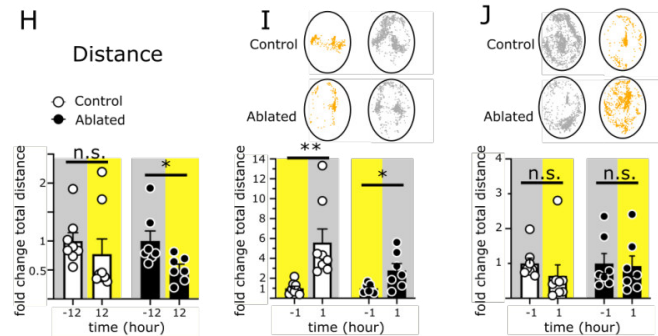

Figure 6

Ablation of Sox $14^{+}$IGL/LGv neurons causes delayed vigilance state transitions at circadian light changes. $\boldsymbol{A}, \boldsymbol{B}$, spectrograms, EEG/EMG traces, and hypnograms over a one-hour period from a representative control mouse and an ablated mouse. $\boldsymbol{C}$, over a 24 -hour period control and Sox $14^{+}$IGL/LGV-ablated mice spend a similar percentage of time in Wake ( $48.24 \% \pm 1.96 \%$ vs $48.22 \% \pm 1.71 \%, p=0.99)$, NREM ( $46.73 \% \pm 1.80 \%$ vs 46.38 $\% \pm 1.71 \%, p=0.89)$ and REM ( $5.03 \% \pm 0.20 \%$ vs $5.39 \% \pm 0.17 \%, p=0.2)$. Values are mean \pm s.e.m., t-test. $D, E$, distribution of Wake, NREM and REM in the two hours preceding and following each light transition. Light and dark hours are shaded in yellow and grey, respectively (see Table 6-1 for comprehensive statistics). $\boldsymbol{F}$, pairwise comparison in the content of Wake, NREM and REM between the hour preceding and each of the two hours following the light to dark transition. Control group: Wake-1: $33.17 \% \pm 2.98 \%$, Wake $1: 80.26 \% \pm 3.49 \%$, $\mathrm{p}<0.0001$, Wake $2: 72.61 \% \pm 7.76 \%, p=0.001 ;$ NREM $_{-1}: 60.08 \% \pm 2.65 \%$, NREM $_{1}: 18.39 \% \pm 3.29 \%, p=0.0001$, NREM $_{2}: 25.17 \% \pm 7.04 \%, p=0.0015$; REM $-1: 6.75 \% \pm 0.52 \%$, REM $_{1}: 1.35 \% \pm 0.45 \% p=0.0004$, REM $_{2}: 2.18 \% \pm$ $0.85 \% \mathrm{p}=0.007$. Ablated group: Wake $136.57 \% \pm 5.34 \%$, Wake $1: 56.67 \% \pm 3.49 \%, \mathrm{p}=0.093$, Wake $: 75.23$ $\% \pm 7.24 \%, p=0.008$; NREM $-156.35 \% \pm 4.73 \%$, NREM $_{1}: 38.19 \% \pm 7.68 \%, p=0.093$, NREM $_{2}: 22.36 \% \pm 6.64$ $\%, p=0.0081 ; R^{R E M}-1: 7.08 \% \pm 0.78 \%$, REM $_{1}: 5.10 \% \pm 1.16 \%, p=0.296, \operatorname{REM}_{2}: 2.41 \% \pm 0.90 \%, p=0.031$.

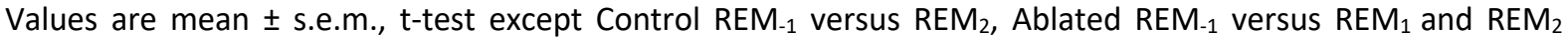
Wilcoxon test. G, pairwise comparison in the content of Wake, NREM and REM between the hour preceding and each of the two hours following the dark to light transition. Control group: Wake-1: $94.77 \% \pm 3.48 \%$, Wake ${ }_{1}$ : $63.47 \% \pm 9.42 \%, p=0.015$, Wake $_{2}: 36.11 \% \pm 9.72 \%, p=0.015 ;$ NREM $_{-1}: 5.22 \% \pm 3.48 \%$, NREM$_{1}: 34.87 \% \pm$ $8.82 \% p=0.015$, NREM $_{2}: 57.51 \% \pm 8.86 \% p=0.015 ;$ REM $_{-1}: 0.00 \% \pm 0.00 \%$, REM $_{1}: 1.66 \% \pm 0.64 \%, p=0.125$, REM $_{2}: 6.37 \% \pm 1.09 \%, p=0.015$. Ablated group: Wake $-19.18 \% \pm 7.51 \%$, Wake $1: 82.47 \% \pm 7.80 \%, p=0.812$, Wake $_{2}: 39.37 \% \pm 8.09 \%, p=0.017$; NREM $-120.50 \% \pm 7.34 \%$, NREM $1: 17.25 \% \pm 7.65 \%, p=0.848$, NREM $_{2}$ : $56.31 \% \pm 7.22 \%, p=0.021 ;$ REM $_{-1}: 0.31 \% \pm 0.21 \%$, REM $_{1}: 0.27 \% \pm 0.20 \%, p>0.999$, REM $_{2}: 4.31 \% \pm 1.34 \%$, $\mathrm{p}=0.0313$. Values are mean \pm s.e.m., Wilcoxon test except Ablated Wake-1 versus Wake ${ }_{2}$ and NREM-1 versus $\mathrm{NREM}_{2}$ t-test. $\boldsymbol{H}$, fold change in distance travelled in the light phase (12 hours). Total distance in the dark phase 
bioRxiv preprint doi: https://doi.org/10.1101/2022.02.24.481804; this version posted February 25,2022 . The copyright holder for this preprint (which was not certified by peer review) is the author/funder, who has granted bioRxiv a license to display the preprint in perpetuity. It is made available under aCC-BY-NC-ND 4.0 International license.

Brock et al.

(12 hours) was set at 1 . Control group: $1.0 \pm 0.14$ (dark) versus $0.77 \pm 0.26$ (light); Ablated group: $1.0 \pm 0.17$ (dark) versus $0.52 \pm 0.82$ (light). $I$, Example trajectories for one control and one ablated mouse in the hour preceding and following the light change. Oval: ROI used for automated tracking; yellow: light, grey: dark. Histograms report the fold change in distance travelled in the hour preceding and following the light change. For the light to dark transition distance in the light was set at 1: Control group $1.0 \pm 0.21$ (light) $5.59 \pm 1.36$ (dark), $\mathrm{p}=0.0078$; Ablated group $1.0 \pm 0.17$ (light) $2.80 \pm 0.68$ (dark), $\mathrm{p}=0.044$. J, For the dark to light transition distance in the dark was set at 1 : Control group $1.0 \pm 0.15$ vs $0.64 \pm 0.31, p=0.148$; Ablated group $1.0 \pm 0.28$ vs $0.92 \pm 0.29, p=0.468$. Values are mean \pm s.e.m., Wilcoxon test except for Ablated light to dark transition t-test. A summary of statistical tests is available in Table 6-1.

To monitor the impact of ablating the Sox $14^{+}$IGL/LGv neurons on the vigilance states of the brain at each light transition under standard circadian conditions, we injected male Sox $14^{\text {Cre/+ }}$ mice with either AAV Ef1a-mCherry-DIO-DTA (ablated group) or AAV Ef1a-DIO-CFP (control group) into the IGL/LGv region, replicating the genetic strategy previously described. Control and ablated mice were then implanted with screw type skull electrodes for EEG (Fig. 6-1) and stainless-steel wire type electrodes inserted into the trapezius muscle of the neck for electromyogram (EMG). During the EEG/EMG recording, animals could move freely in their cage. Both ablated and control animals displayed characteristic cortical spectrograms, EEG/EMG traces and hypnograms with detectable transitions between periods of high magnitude delta frequency oscillations and reduced mobility indicative of non-rapid eye movement (NREM) sleep (Fig. 6A,B), and high magnitude theta frequency oscillations occurring either without associated increase in the amplitude of the EMG signal, as is typical of rapid eye movement (REM) sleep, or with associated EMG activity, as is typical of the wake state (Wake; Fig. 6A,B).

Consistent with the pattern of circadian locomotion observed in the cohort of Sox $14^{+}$IGL/LGVablated mice tested for circadian light entrainment, the cumulative fraction of a 24-hour period spent in NREM, REM and Wake states did not differ between ablated and control groups (Fig. $6 \mathrm{C}$ and Table 6-1; NREM: $p=0.89$, REM: $p=0.2$, Wake: $p=0.99$ ), indicating that the Sox $14^{+}$neurons of the IGL/LGv are not required for sleep and wake overall. However, 
bioRxiv preprint doi: https://doi.org/10.1101/2022.02.24.481804; this version posted February 25, 2022. The copyright holder for this preprint (which was not certified by peer review) is the author/funder, who has granted bioRxiv a license to display the preprint in perpetuity. It is made available under aCC-BY-NC-ND 4.0 International license.

Brock et al.

plotting the content of NREM, REM and Wake for each hour of the circadian cycle revealed a discrepancy between ablated and control groups specifically in the hour following each light transition. We further increased the temporal resolution by binning NREM, REM and Wake episodes in 20 minutes intervals for the 2 hours preceding and following each light transition. This analysis revealed that, while both control and ablated animals increased the time spent in Wake in the first 2 hours after lights off (Fig. 6D and Table 6-1 for full statistical data; Wake Control: $p<0.0001 ;$ Wake Ablated: $p=0.015$ ) and conversely, decreased it at lights on (Fig. 6E and Table 6-1; Wake Control: $p<0.0001$, Wake Ablated: $p=0.051$ ), the ablated group remained for a protracted period in a state similar to the one preceding each light transition, responding with a delayed kinetic to the circadian light change (Fig. 6D,E).

To quantitatively assess the impact of circadian light transitions on Wake, NREM and REM states upon ablation of the Sox $14^{+}$IGL/LGv, we plotted the cumulative time spent in each of the three vigilance states during the hour preceding the light change (-1) and the first (1) and the second hour (2) after the light change for the control and ablated groups (Fig. 6F). In the control group, pairwise comparisons between the hour preceding and each of the two hours following the light transition showed a strong and statistically significant change in each of the three vigilance states already in the first hour following the circadian light transition (Fig. 6F and Table 6-1; Wake-1 versus Wake $1: p<0.0001$; NREM-1 versus NREM $1: p=0.0001 ;$ REM$_{-1}$ versus $\left.\mathrm{REM}_{1}: \mathrm{p}=0.0004\right)$. In contrast, change in all three vigilance states in the ablated group does not reach statistical significance during the first hour after the light transition (Fig. 6F and Table 6-1, Wake ${ }_{-1}$ versus Wake $1: p=0.093 ;$ NREM $_{-1}$ versus NREM $1: p=0.093 ;$ REM $_{-1}$ versus $\left.\mathrm{REM}_{1}: p=0.296\right)$. However, in the ablated group, change in Wake and NREM reached statistical significance in the second hour after the light transition (Fig. 6F and Table 6-1; Wake-1 versus Wake $2: p=0.0080 ;$ NREM-1 $_{-1}$ versus NREM$_{2}: p=0.0081$ ), substantiating the 
bioRxiv preprint doi: https://doi.org/10.1101/2022.02.24.481804; this version posted February 25, 2022. The copyright holder for this preprint (which was not certified by peer review) is the author/funder, who has granted bioRxiv a license to display the preprint in perpetuity. It is made available under aCC-BY-NC-ND 4.0 International license.

Brock et al.

interpretation that the Sox $14^{+}$IGL/LGv neurons are required for the rapid change in cortical network activity caused by circadian light transitions, but not for overall regulation of sleep and wake over a 24-hour period.

A

$\mathrm{B}$

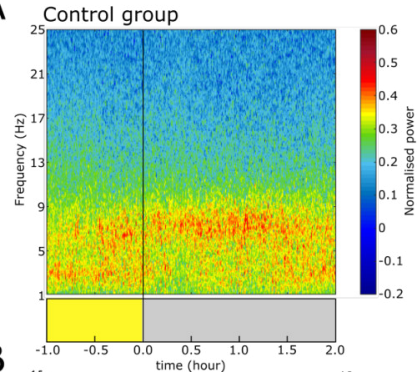

C
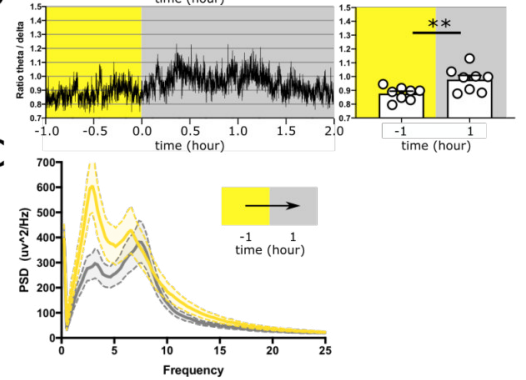

G

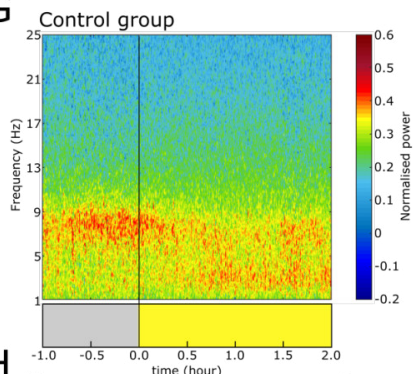

$\mathrm{H}$

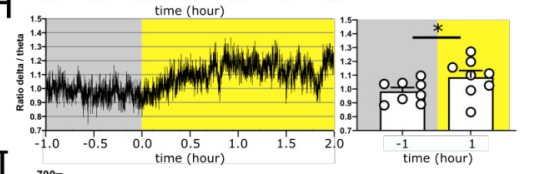

I

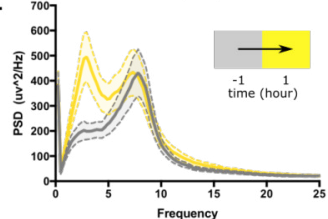

D

E
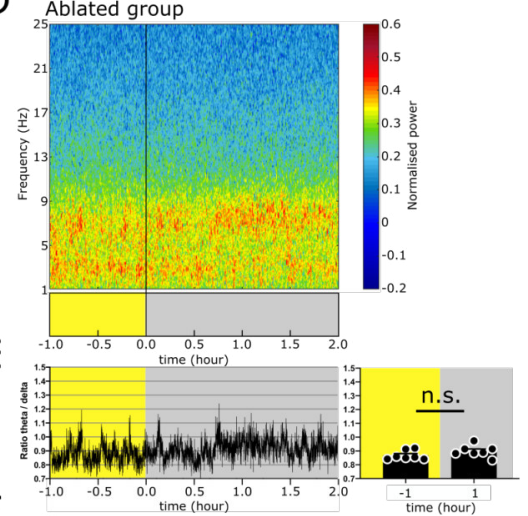

$\mathrm{F}$

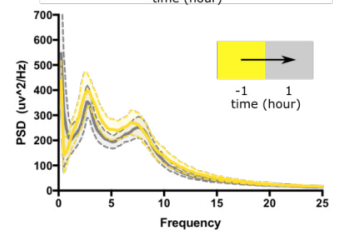

J Ablated group

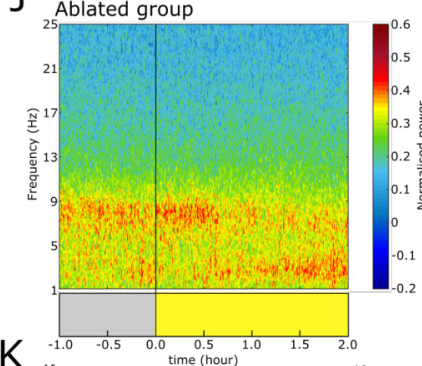

K

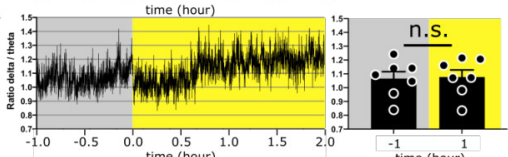

L

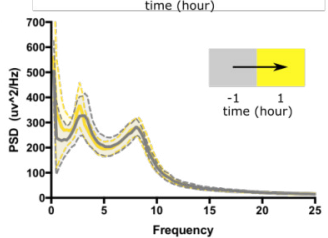

M

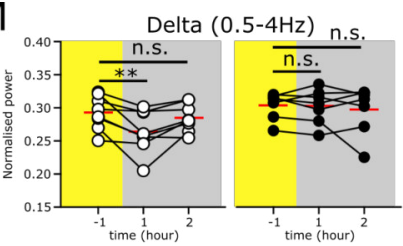

$\mathrm{N}$

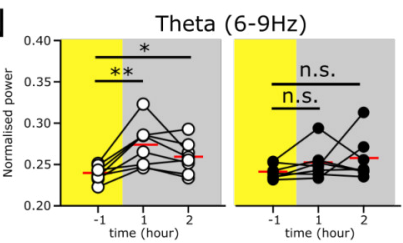

O Alpha $(8-12 \mathrm{~Hz})$

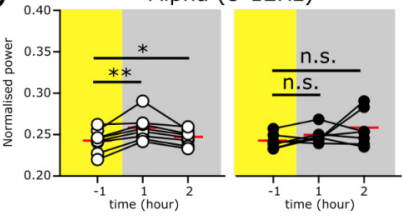

O Control group

- Ablated group

P

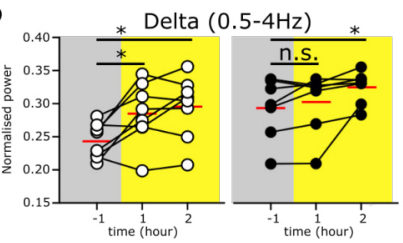

Q

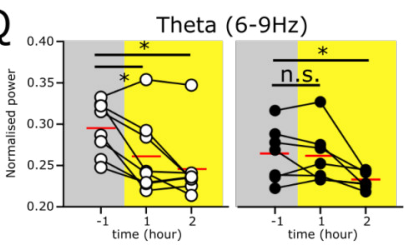

$\mathrm{R}$

Alpha $(8-12 \mathrm{~Hz})$

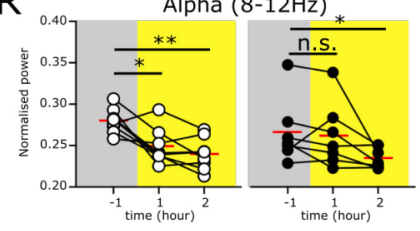

Figure 7:

The Sox $14^{+}$IGL/LGv neurons are required for the rapid onset of cortical network activity associated with circadian light transitions. $\boldsymbol{A}$, averaged cortical spectrogram for the Control group displaying a rapid increase in the theta power and decrease in delta power at the transition from lights on to lights off. $\boldsymbol{B}$, the change in theta and delta is displayed as a group average theta/delta ratio over time and as cumulative for the hour preceding and the hour following the light change. Control group (T/D) $)_{-1}: 0.87 \pm 0.01$ versus $(T / D)_{1}: 0.97 \pm 0.03, p=0.001$. Values are mean \pm s.e.m., t-test. $C$, the power spectrum of the Control group in the hour preceding the transition from light to dark is overlayed to the power spectrum profile for the hour following the light transition (bold line: mean; dotted lines: \pm s.e.m.; yellow: light, grey: dark). $\boldsymbol{D}$, averaged cortical spectrogram for the Ablated group displaying retention of high delta power following the lights on to lights off transition. $\boldsymbol{E}$, the change in theta and delta is displayed as a group average theta/delta ratio over time and as cumulative for the hour 
bioRxiv preprint doi: https://doi.org/10.1101/2022.02.24.481804; this version posted February $25,2022$. The copyright holder for this preprint (which was not certified by peer review) is the author/funder, who has granted bioRxiv a license to display the preprint in perpetuity. It is made available under aCC-BY-NC-ND 4.0 International license.

Brock et al.

preceding and the hour following the light change. Ablated group (T/D) $-1: 0.86 \pm 0.01$ versus (T/D) $1: 0.89 \pm 0.01$, $p=0.078$. Values are mean \pm s.e.m., Wilcoxon test. $\boldsymbol{F}$, the power spectrum of the Ablated group in the hour preceding the transition from light to dark is overlayed to the power spectrum profile for the hour following the light transition (bold line: mean; dotted lines: \pm s.e.m.; yellow: light, grey: dark). $\mathbf{G}$, averaged power spectrum for the Control group in the hour preceding and the two hours following the lights off to lights on transition. $\boldsymbol{H}$, the change in the delta/theta ratio is plotted over time and as group mean for the hour preceding and following the light transition. Control group $(D / T)_{-1}: 0.98 \pm 0.02$ versus $(D / T)_{1}: 1.08 \pm 0.04, p=0.016$. Values are mean \pm s.e.m, t-test. $I$, the power spectrum of the Control group in the hour preceding the transition from dark to light overlayed to the power spectrum profile for the hour following the light transition (bold line: mean; dotted lines: \pm s.e.m.; yellow: light, grey: dark). $J, L$, the same analysis as in G-H is applied to the Ablated group. Note that the Ablated group does not display a significative change in the delta/theta ratio. Ablated group (D/T) $-1: 1.06 \pm 0.05$ versus $(D / T)_{1}: 1.07 \pm 0.05, p=0.623$. Values are mean \pm s.e.m., $t$-test. $M$, pairwise comparison for the delta power for the hour preceding and each of the two hours following the transition from lights on to lights off in the Control group (white circles) and Ablated group (filled black circles). Control group Delta-1: $0.29 \pm 0.009$, Delta $_{1}: 0.26 \pm 0.01 p=0.009$, Delta $2: 0.28 \pm 0.007 p=0.323$. Values are mean \pm s.e.m., t-test. Ablated group Delta-1: $0.30 \pm 0.007$, Delta 1 : $0.30 \pm 0.009 p=0.734$, Delta $2: 0.29 \pm 0.013 p=0.937$. Values are mean \pm s.e.m., Wilcoxon test. $\mathbf{N}$, pairwise comparison for the theta power for the hour preceding and each of the two hours following the transition from lights on to lights off in the Control group (white circles) and Ablated group (filled black circles). Control group Theta ${ }_{-1}: 0.23 \pm 0.003$, Theta $a_{1}: 0.27 \pm 0.009, p=0.002$, Theta $_{2}: 0.25 \pm 0.006, p=0.105$. Values are mean \pm s.e.m., $t$-test. Ablated group Theta $-1: 0.24 \pm 0.003$, Theta 1 : 0.25 $\pm 0.007 p=0.109$, Theta $_{2}: 0.25 \pm$ $0.01, p=0.109$. Values are mean \pm s.e.m., Wilcoxon test. $\boldsymbol{O}$, pairwise comparison for the alpha power for the hour preceding and each of the two hours following the transition from lights on to lights off in the Control group (white circles) and Ablated group (filled black circles). Control group Alpha 1 : $0.24 \pm 0.004$, Alpha $_{1}: 0.25 \pm$ $0.005, p=0.003$, Alpha $: 0.24 \pm 0.003, p=0.045$. Values are mean \pm s.e.m., t-test. Ablated group Alpha-1: 0.24 \pm 0.003, Alpha $_{1}: 0.24 \pm 0.003, p=0.109$, Alpha $: 0.25 \pm 0.008, p=0.097$. Values are mean \pm s.e.m., Wilcoxon test. $\boldsymbol{P}, \boldsymbol{R}$, similar pairwise analysis as in $\mathrm{M}-\mathrm{O}$ but for the transition from lights off to lights on. Control group Delta 1 : $0.24 \pm 0.009$, Delta 1 : 0.28 $\pm 0.016, p=0.009$, Delta $2: 0.29 \pm 0.016, p=0.019$. Ablated group Delta -1 : 0.29 \pm 0.017 , Delta $1: 0.30 \pm 0.017, p=0.296$, Delta $2: 0.32 \pm 0.009, p=0.036$. Values are mean \pm s.e.m., t-test except for the Ablated group Delta ${ }_{2}$ comparison which used a Wilcoxon test. Control group Theta $1: 0.29 \pm 0.011$, Theta $_{1}$ : $0.26 \pm 0.016, p=0.023$, Theta $2: 0.24 \pm 0.014, p=0.023$. Values are mean \pm s.e.m., Wilcoxon test. Ablated group Theta-1: $0.26 \pm 0.012$, Theta $_{1}: 0.26 \pm 0.012, p=0.706$, Theta $2: 0.23 \pm 0.003, p=0.038$. Values are mean \pm s.e.m., t-test. Control group Alpha-1: $0.27 \pm 0.005$, Alpha $1: 0.24 \pm 0.007, p=0.012$, Alpha $: 0.23 \pm 0.006, p=0.005$. Values are mean \pm s.e.m, t-test. Ablated group Alpha-1: $0.26 \pm 0.014$, Alpha 1 : 0.26 $\pm 0.014, p=0.375$, Alpha $_{2}: 0.23 \pm$ $0.004, p=0.046$. Values are mean \pm s.e.m., Wilcoxon test. A summary of statistical tests is available in Table 71.

We then investigated whether a similar requirement for the Sox $14^{+} \mathrm{IGL} / \mathrm{LGv}$ neurons also exists at the dark to light transition. In the control group, the time spent in Wake, NREM and REM over the 3-hour period changed significantly (Table 6-1 for full statistical data).

In keeping with the observed rapid changes in vigilance states at light to dark transition (Fig. 4F), rapid changes in Wake and NREM were also detected already in the first hour after the transition to lights-on (Fig. $6 \mathrm{G}$ and Table 6-1; Wake-1 versus Wake 1 : $p=0.015$; NREM-1 versus NREM $_{1}: p=0.015 ;$ REM-1 $_{-1}$ versus REM $\left.1: p=0.125\right)$. However, in the ablated group, significant changes in the three vigilance states only became apparent in the second hour after the light 
bioRxiv preprint doi: https://doi.org/10.1101/2022.02.24.481804; this version posted February 25, 2022. The copyright holder for this preprint (which was not certified by peer review) is the author/funder, who has granted bioRxiv a license to display the preprint in perpetuity. It is made available under aCC-BY-NC-ND 4.0 International license.

Brock et al.

transition (Fig. 6G and Table 6-1; Wake-1 versus Wake $2: p=0.017$; NREM-1 versus NREM $: p=$ 0.021; REM-1 versus REM $: p=0.031$ ). Hence, Sox $14^{+}$IGL/LGv neurons are required at both circadian light transitions to elicit rapid transitions between vigilance states.

While delayed responses to the circadian light transitions caused by the ablation of Sox $14^{+}$ IGL/LGv neurons could readily be detected in the EEG/EMG data, we noted that they correlated less clearly with overt motor behaviour. Change in the distance travelled before and after the circadian light transitions, assessed by automated video tracking (Pinnacle Technologies, Inc.) of animals undergoing EEG/EMG recordings, did not reveal similarly striking changes within and between groups (Fig. 6H,I,J and Table 6-1).

We therefore focused our analysis on cortical network activity rather than behavioural output and extended the analysis of the EEG data to quantify oscillatory activity in the delta (0.5$4 \mathrm{~Hz})$, theta $(6-9 \mathrm{~Hz})$ and alpha $(8-12 \mathrm{~Hz})$ frequency ranges. High power delta oscillations are typically observed during NREM, while theta oscillations are associated with REM sleep as well as exploratory behaviour and alpha oscillations are enriched during quiet wake.

Power spectral densities displayed dynamic changes at either circadian light transition in both the control (Fig. 7A,G) and the ablated group (Fig. 7D,J). In the control group, time-frequency analysis of EEG data showed the presence of delta waves dominating the hour preceding the light to dark transition, with the appearance of theta and low alpha waves anticipating the light change and a sharp decrease in delta following the transition (Fig. 7A). The clear shift from delta to theta waves in the control group was supported by a theta/delta ratio (T/D) that was significantly increased after the circadian light change (Fig. 7B and Table 7-1; (T/D)-1 versus $\left.(T / D)_{1} p=0.0016\right)$ and the clear frequency shift from high delta and low theta state in the hour preceding the light transition (Fig. 7C, yellow line) to high theta and low delta state in the hour following the light transition (Fig. 7C, grey line). 
bioRxiv preprint doi: https://doi.org/10.1101/2022.02 24.481804 t this version posted February 25,2022 . The copyright holder for this preprint (which was not certified by peer review) is the author/funder, who has granted bioRxiv a license to display the preprint in perpetuity. It is made available under aCC-BY-NC-ND 4.0 International license.

Brock et al.

In stark contrast, the spectrogram of EEG data from the Sox $14^{+}$IGL/LGv ablated mice showed a mixture of delta, theta and low-alpha waves in the hour before the light transition. Delta waves continued to be present for the first hour after the light transition, eventually fading in the second hour, when theta and low-alpha oscillations increased (Fig. 7D). Consequently, there was no significant change in T/D ratio (Fig. 7E; $(T / D)_{-1}$ versus $(T / D)_{1}: p=0.078$ ) and power spectral densities showed similar spectral patterns before (Fig. 5F, yellow line) and after the light transition (Fig. 7F, grey line). These observations are consistent with delayed cortical network dynamics at the lights-on to lights-off transition in mice with Sox $14^{+}$IGL/LGV ablation.

We then performed the same analysis for the lights-off to lights-on transition of the circadian day, which is normally accompanied by sleep onset. As expected, spectrograms from the control mice showed the presence of theta and low-alpha waves in the hour preceding the light transition, which shifted to high amplitude delta and reduced theta and low-alpha waves already within the first hour following the light transition (Fig. 7G). This clear shift from theta to delta waves in the control group was reflected in the increased delta/theta ratio (D/T) (Fig. 7H and Table 7-1; $(D / T)_{-1}$ versus $\left.(D / T)_{1}: p=0.0168\right)$.

Similarly, power spectral density showed a clear frequency shift from high amplitude theta and low delta in the hour preceding the light transition (Fig. 7I, grey line) to high delta and low theta within the first hour following the light transition (Fig. 7l, yellow line).

The ablated mice differed from the control group as theta and low alpha waves persisted for approximately 40 minutes following the light transition, after which they faded and were replaced by delta oscillations (Fig. 7J). Consequently, there was no significant change in D/T ratio in the hour preceding and following the light transition (Fig. $7 K ;(D / T)_{-1}$ versus $(D / T)_{1}: p$ 
bioRxiv preprint doi: https://doi.org/10.1101/2022.02 24.481804 t this version posted February 25,2022 . The copyright holder for this preprint (which was not certified by peer review) is the author/funder, who has granted bioRxiv a license to display the preprint in perpetuity. It is made available under aCC-BY-NC-ND 4.0 International license.

Brock et al.

$=0.623$ ) and power spectral densities retained similar distribution before (Fig. 7L, grey line) and after the light transition (Fig. 7L, yellow line).

To assess quantitatively the change in power for the delta, theta and alpha ranges, we calculated the cumulative power for the hour preceding and for the first and second hour following each circadian light transition, starting first from lights-on to lights-off. Across the three time points, animals in the control group showed significant change for all three frequency bands (Fig. 7M,N,O; Delta $p=0.0064$, Theta $p=0.0012$, Alpha $p=0.0031$ ). Delta power decreased significantly already in the first hour after the light transition (Fig. 7M and Table 7-1; Delta-1 versus Delta $1 \mathrm{p}=0.0099)$. Concomitantly, the theta power increased significantly (Fig. $7 \mathrm{~N}$ and Table 7-1; Theta-1 versus Theta $1: \mathrm{p}=0.0027$ ) as did alpha power (Fig. 70 and Table 7-1; Alpha-1 versus Alpha $1: p=0.0039)$. In contrast, the group of animals with ablation of the Sox $14^{+}$neurons in the IGL/LGv did not display significant overall change in the power of delta, theta and alpha across the three timepoints (Fig. 7M,N,O and Table 7-1 for comprehensive statistical data).

We then performed the quantitative analysis on the combined hourly variation in delta, theta and alpha for the second circadian light transition of the day, corresponding to lights off to lights on. As expected, significant difference was detected in the control group (Delta: $p=$ 0.011, Theta: $p=0.030$, Alpha: $p=0.0029$ ). Pair-wise comparisons between the hour preceding and each of the two hours following the circadian light change confirmed a significant increase in delta power taking place already in the first hour (Fig. 7P and Table 71; Delta-1 versus Delta $: p=0.019)$, accompanied by a significant decrease in theta power (Fig. $7 Q$ and Table 7-1; Theta-1 versus Theta 1 : $P=0.023$ ) and alpha power (Fig. 7R and Table 7-1; Alpha-1 versus Alpha $1: p=0.0124)$. 
bioRxiv preprint doi: https://doi.org/10.1101/2022.02 24.481804 t this version posted February 25,2022 . The copyright holder for this preprint (which was not certified by peer review) is the author/funder, who has granted bioRxiv a license to display the preprint in perpetuity. It is made available under aCC-BY-NC-ND 4.0 International license.

Brock et al.

In contrast, in the Sox $14^{+} \mathrm{IGL} / \mathrm{LGV}$ ablated group, delta and alpha power did not change significantly across the three time points (Fig. 7P,R and Table 7-1; Delta: $p=0.051$, Alpha: $p=$ 0.111). Power in the Theta frequency across all time points showed a significant difference (Table 7-1; Theta: $p=0.028$ ), which was due to a decrease in power in the second hour after the transition (Fig. 7Q and Table 7-1; Theta-1 versus Theta $1: p=0.706$, Theta-1 versus Theta ${ }_{2}$ : $p=0.038)$

In summary, power spectral analysis of cortical EEG reveals a previously undescribed role for the thalamic neurons in the IGL/LGv in enabling rapid changes in cortical network activity at both circadian light changes.

\section{Sox $14^{+}$neurons in the IGL/LGv and pHB are related}

In mice, thalamic GABA projection neurons are also present in the pHB (An et al., 2020). We and others have previously described Sox $14^{+}$GABAergic precursors that during embryonic development migrate tangentially from the presumptive IGL/LGv to reach the location of the presumptive pHB (Fig. 1A), indicating a developmental lineage relationship between GABA projection neurons in these two thalamic structures (Delogu et al., 2012; Vue et al., 2007). To test whether Sox $14^{+}$neurons in the IGL/LGv and the pHB retain shared patterns of connectivity, we adapted the transsynaptic RVdG strategy previously used to map synaptic input to the Sox $14^{+}$neurons of the IGL/LGv to the Sox $14^{+}$cells in the pHB (Fig. 8A,B). Anatomical mapping of the input to the Sox $14^{+}$neurons of the $\mathrm{pHB}$ revealed an overall striking similarity with the input to the Sox $14^{+}$neurons of the IGL/LGv with a large fraction arising in the subcortical visual shell (Fig. 8F and Table 4-1). In contrast to the Sox14+ IGL/LGv neurons, the Sox $14^{+}$neurons of the $\mathrm{pHB}$ did not receive detectable retinal input, nor input from the 
bioRxiv preprint doi: https://doi.org/10.1101/2022.02.24.481804; this version posted February 25, 2022. The copyright holder for this preprint (which was not certified by peer review) is the author/funder, who has granted bioRxiv a license to display the preprint in perpetuity. It is made available under aCC-BY-NC-ND 4.0 International license.

Brock et al.

primary cortical visual area. However, they displayed a sizeable input ( $20 \%)$ from the IGL/LGv

(Fig. 8C,D,E) and from subcortical and cortical limbic structures (Fig. 8C,F and Table 4-1).

A AAV EF1a-FLEX-TVA-mCherry-EF1a t- MuayJu-YNL-1-WPRE-

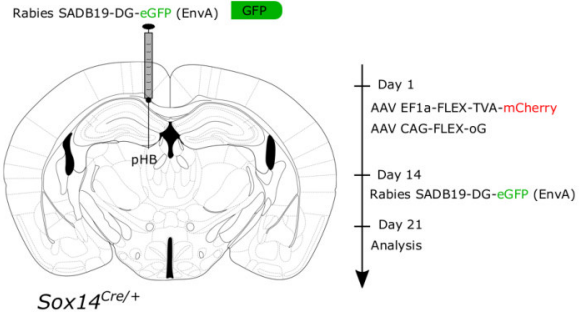

B
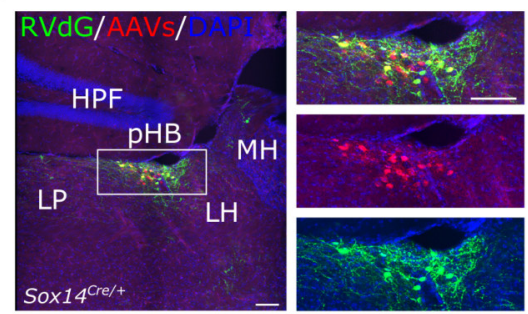

C

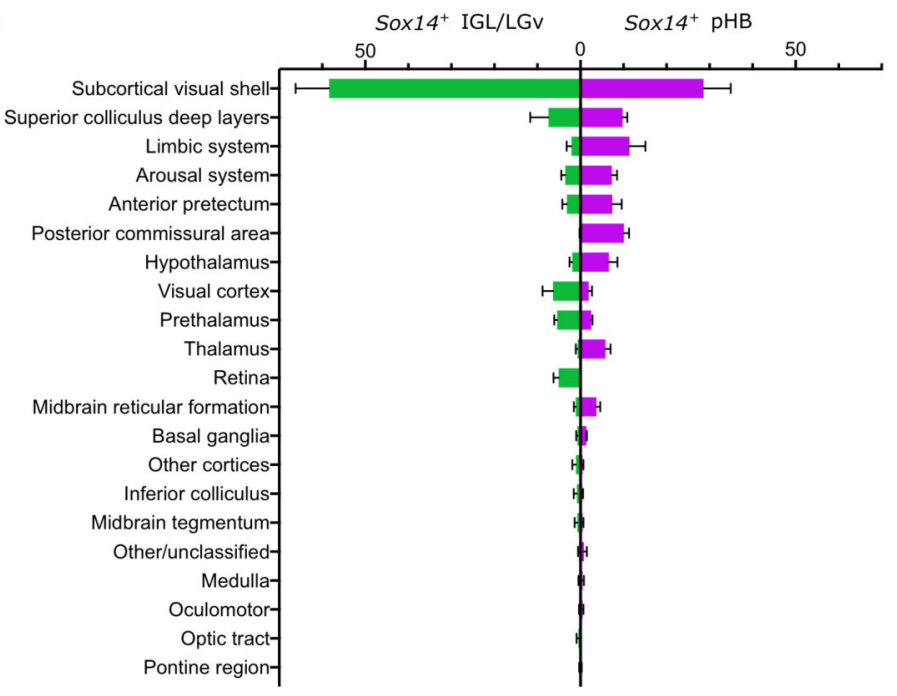

$\mathrm{D}$

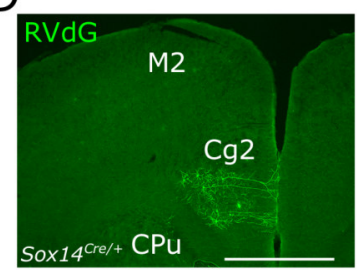

$G$

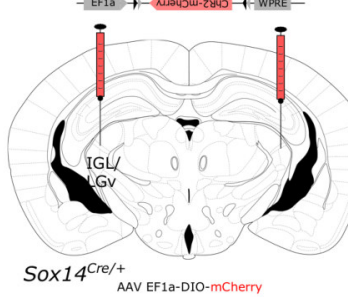

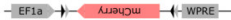
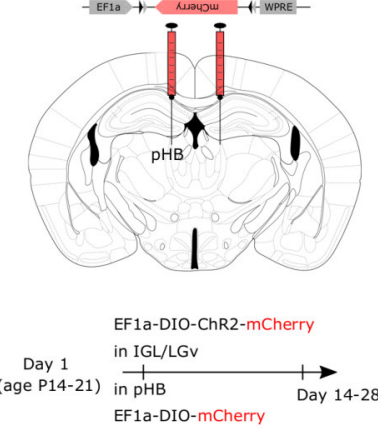

$E$

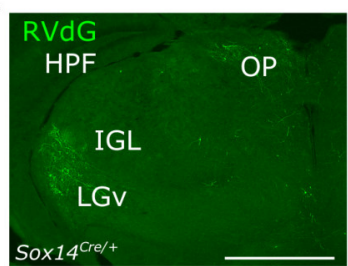

$\mathrm{H}$

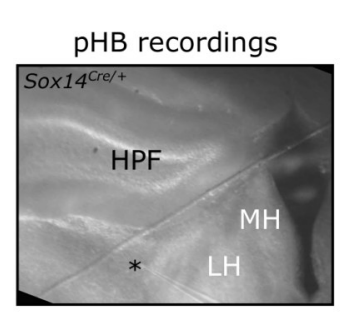

K
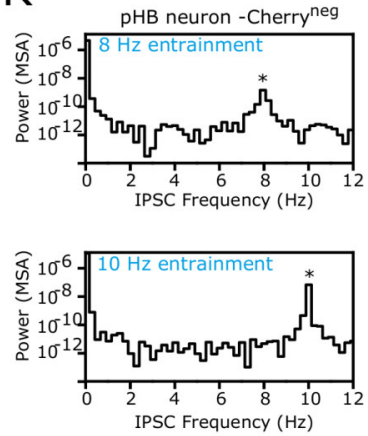

I

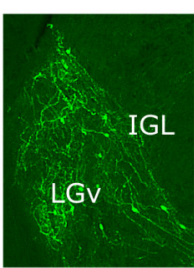

$\mathrm{F}$

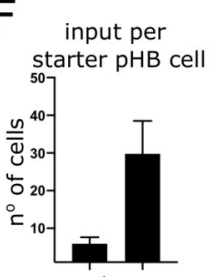

]
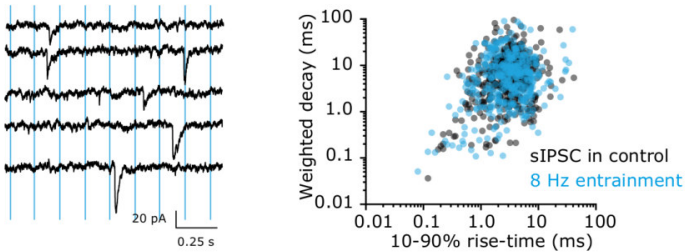

pHB neuron -Cherryeg
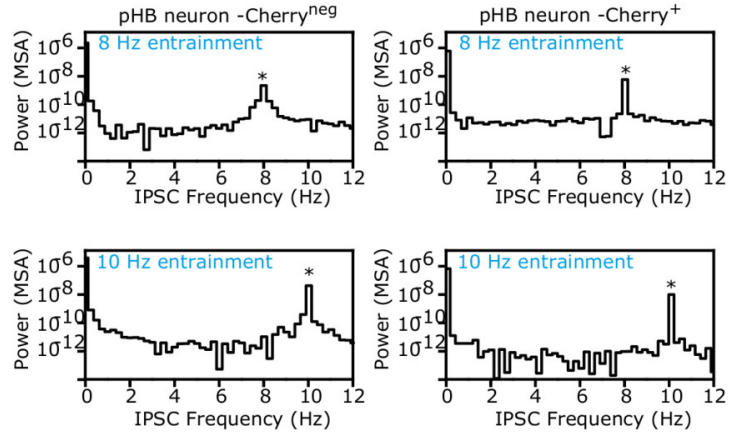

Figure 8.

Developmentally related Sox $14^{+}$neurons in the IGL/LGv and pHB retain a large proportion of shared input. $\boldsymbol{A}$, scheme of rabies tracing in Sox $14^{\text {Cre/+ }}$ line, showing the location of the injection site $(\mathrm{pHb})$ and the viruses used. 
bioRxiv preprint doi: https://doi.org/10.1101/2022.02.24.481804; this version posted February 25,2022 . The copyright holder for this preprint (which was not certified by peer review) is the author/funder, who has granted bioRxiv a license to display the preprint in perpetuity. It is made available under aCC-BY-NC-ND 4.0 International license.

Brock et al.

$B$, representative coronal section of the injection site, showing starter cells (GFP+RFP ${ }^{+}$double-positive neurons) within the pHB. Green, GFP from RVdG; red, mCherry from AAVs. HPF: hippocampal formation, LP: lateral posterior, LH: lateral habenula, $\mathrm{MH}$ : medial habenula. Scale bar $100 \mu \mathrm{m}$. C, quantification of inputs to Sox14 neurons of $\mathrm{pHB}$ (right, $\mathrm{n}=3$ mice) from anatomically defined regions, compared to input to the Sox $14^{+}$neurons in the IGL/LGv (left, $n=4$ mice) from the same anatomical regions. Data are shown as percent of total number of cells (mean \pm s.e.m.). $D$, representative coronal sections of the brain-wide distribution of inputs to Sox $14^{+}$ neurons of pHB. M2: secondary motor cortex, Cg2: cingulate cortex area 2, CPu: caudate putamen. Scale bar $100 \mu \mathrm{m}$. $\boldsymbol{E}$, representative coronal section at thalamic level showing the presynaptic neurons in the IGL/LGV innervating the Sox $14^{+}$neurons in the pHB. HPF: hippocampal formation, OP: olivary pretectal nucleus. Scale bar $100 \mu \mathrm{m} . \boldsymbol{F}$, the normalised IGL/LGv input $(5.93 \pm 1.68)$ is a sizable fraction of all brain wide afferents $(29.77 \pm$ 8.75) to the pHB. Inputs are normalised for the number of starter cells in the pHB. mean \pm s.e.m.; $n=3$ mice. $\boldsymbol{G}$, strategy to introduce ChR2 in Sox $14^{+}$IGL/LGv neurons and mCherry in Sox $14^{+}$pHB neurons. $\boldsymbol{H}$, example of the acute brain preparation illustrating the location of a patched cell. $I$, postsynaptic currents in pHB neurons from an acute preparation upon $8 \mathrm{~Hz}$ light stimulation of $\mathrm{ChR2}$-expressing axonal terminals. $J$, peristimulus time histogram analysis of sIPSCs. $\boldsymbol{K}$, examples of entrained activity in pHB neurons with or without mCherry expression upon laser stimulation at $8 \mathrm{~Hz}$ and $10 \mathrm{~Hz}$.

These data complement our observation of monosynaptic input from the area of the pHB to the Sox $14^{+}$neurons of the IGL/LGv (Fig. 4B) and suggest that the thalamic Sox $14^{+}$neurons of the IGL/LGv and the pHB retain a large proportion of shared input, but with specific differences such as retinal and prefrontal limbic inputs. Following AAV delivery of ChR2 (EF1aDIO-ChR2-mCherry) to neurons of the IGL/LGv in the Sox14 ${ }^{\text {Cre/t }}$ mouse (Fig. 8G) we attempted to record from mCherry expressing neurons within the pHB (Fig. $8 \mathrm{H}$ ) that had been injected with a second AAV (EF1a-DIO-mCherry). The very low number of viable mCherry-expressing neurons within the pHB hindered functional identification of monosynaptic connectivity between IGL/LGv and pHB. However, peristimulus time histogram (PSTH) analysis of sIPSC timing (Fig. $81, \mathrm{~J})$ in $\mathrm{mCherry}^{+}$and $\mathrm{mCherry}^{\text {neg }}$ neurons of the $\mathrm{pHB}(\mathrm{n}=3$ mice) supports the presence of entrained activity resulting from optogenetic stimulation of the Sox $14^{+}$IGL/LGV input (Fig. 8K).

Intrigued by the possibility of an IGL/LGv input to the $\mathrm{pHB}$, we aimed to further characterise the Sox $14^{+}$neurons in the $\mathrm{pHB}$ by identifying their axonal projections and compare these with those of other recently described $\mathrm{pHB}$ cell types such as the ventral pHB neurons that projects to the ventromedial prefrontal cortex (vmPFC) (An et al., 2020; Fernandez et al., 2018) and 
bioRxiv preprint doi: https://doi.org/10.1101/2022.02 24.481804 t this version posted February 25,2022 . The copyright holder for this preprint (which was not certified by peer review) is the author/funder, who has granted bioRxiv a license to display the preprint in perpetuity. It is made available under aCC-BY-NC-ND 4.0 International license.

Brock et al.

the GABAergic neurons of the dorsal pHB that project to the nucleus accumbens (An et al., 2020). To achieve this, we injected in the $\mathrm{pHB}$ of Sox $14^{\mathrm{Cre} /+}$ mice either a cre-dependent AAV expressing a cell membrane-bound form of GFP (AAV2/1 Ef1a-DIO-mGFP; Fig. 9A) or a presynaptic-localised Synaptophysin-GFP fusion (AAV2/1 phSyn1(S)-FLEX-tdTomatoSypEGFP; Fig. 9D). The AAV-labelled Sox14+ pHB neurons (Fig. 9B) occupy an area with dense axonal projections from the Sox $14^{+}$IGL/LGv (Fig. 9B'). The axonal projections of the Sox $14^{+}$ pHB extend along two main directions: rostro-ventral, along the lateral thalamus to terminate in the IGL/LGv and medial, penetrating the habenular complex (Fig. 9B,C) and terminating predominantly in the medial habenula (MH; Fig. 9C,E,F,G). The presynaptic terminals of Sox $14^{+}$pHB neurons are enriched in a Calb2 ${ }^{+}$Chat $^{\text {neg }}$ domain in the dorsal portion of the $\mathrm{MH}$ (Fig. 9E,F) and, in keeping with the shared developmental origin with the thalamic component of the IGL/LGv, contained the GABA transporter vGat (Fig. 9G). Hence, our structural and functional connectivity data support a model whereby tangential migration of Sox $14^{+}$ precursors from the developing IGL/LGv to the pHB enables formation of a thalamic network of GABAergic neurons which may represent a previously undescribed substrate for thalamic limbic functions.

\section{The Sox $14^{+}$neurons of the IGL/LGv and pHB participate in mood homeostasis}

Recent reports have shown how both the IGL/LGv and pHB participate in mood regulation (An et al., 2020; Fernandez et al., 2018; Huang et al., 2019). The discovery of a projection from Sox $14^{+} \mathrm{pHB}$ neurons to the dorsal $\mathrm{MH}$ is intriguing, because the $\mathrm{MH}$ participates in the modulation of ventral midbrain dopaminergic and serotonergic neurons via the fasciculus retroflexus projection to inhibitory interneurons in the rostral part of the interpeduncular nucleus (Lima et al., 2017). 
bioRxiv preprint doi: https://doi.org/10.1101/2022.02.24.481804; this version posted February 25, 2022. The copyright holder for this preprint (which was not certified by peer review) is the author/funder, who has granted bioRxiv a license to display the preprint in perpetuity. It is made available under aCC-BY-NC-ND 4.0 International license.

Brock et al.

We hypothesised that the Sox $14^{+}$neurons in the IGL/LGv and pHB may be part of a previously undescribed circuitry for mood regulation. As proof of principle of a shared participation of the two groups of thalamic Sox $14^{+}$neurons in reward pathways, we performed a targeted ablation of the Sox $14^{+}$neurons in the pHB by stereotaxic viral delivery of DTA or control CFP in Sox $14^{\mathrm{Cre} /+}$ male mice, as previously described (Fig. 9H and Fig. 9-1). We then assessed behavioural changes in adult Sox $14^{+} \mathrm{pHB}$ ablated mice by evaluating anhedonia, using the sucrose preference test (SP) and behavioural despair, using the forced swim test (FST), while maintaining animals in standard single housing conditions.
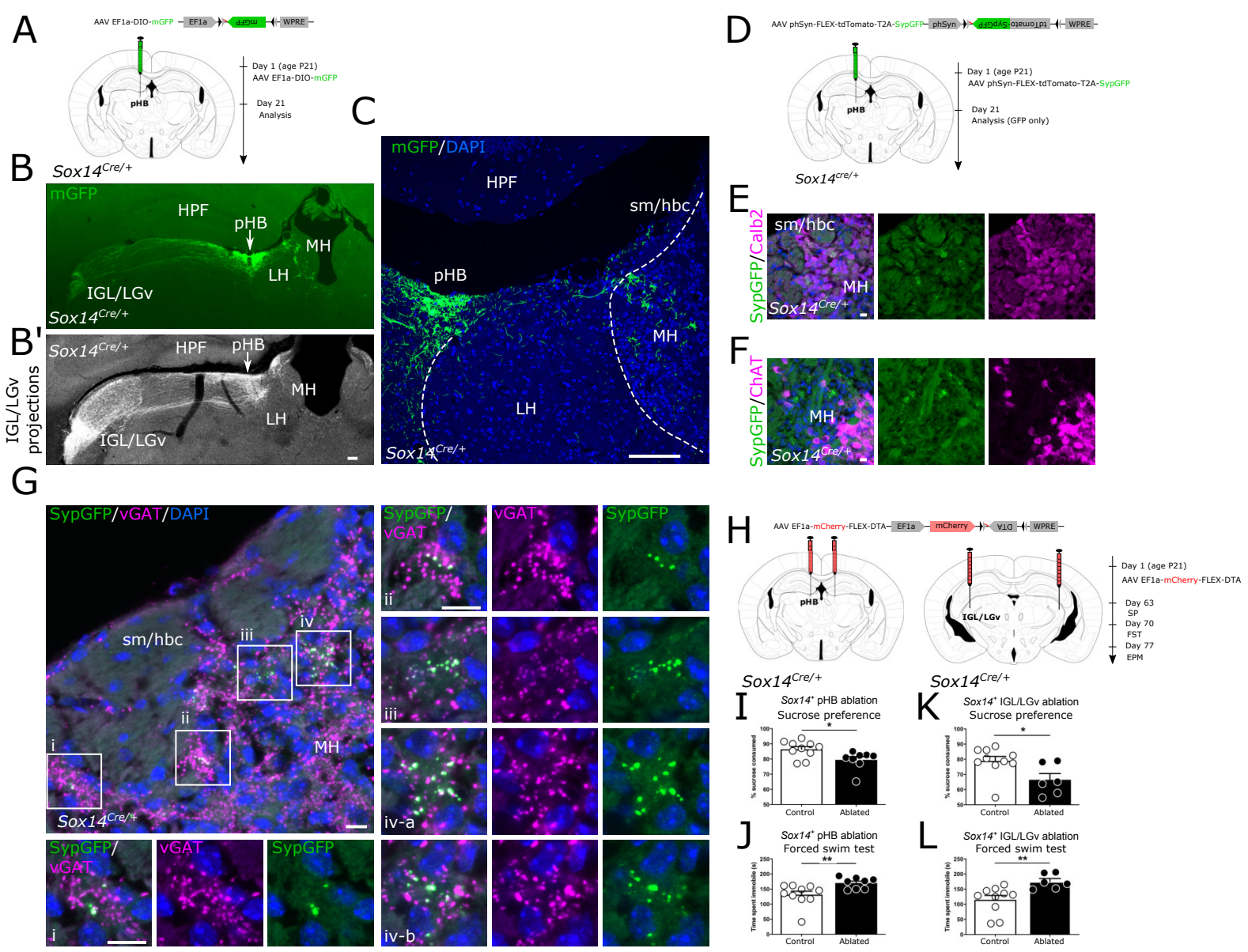

\section{Figure 9.}

The Sox $14^{+}$IGL/LGv and $\mathrm{pHb}$ neurons are part of a thalamic network for mood regulation. $\boldsymbol{A}$, scheme of injection of Cre-dependent AAV expressing mGFP in pHB of Sox $14^{\text {Cre/t }}$ mice. $B, B^{\prime}$, representative coronal sections showing the reciprocal projections between the IGL/LGV and the pHB. In $B^{\prime}$, for comparison the projections of the Sox $14^{+}$ IGL/LGv. Green, mGFP. Scale bar $100 \mu \mathrm{m}$. $\boldsymbol{C}$, representative coronal section showing the injection site and the second route of projections from the $\mathrm{pHB}$, terminating in the $\mathrm{MH}$. Green, mGFP. Sm: stria medullaris, hbc: habenular commissure. Scale bar $100 \mu \mathrm{m}$. $\boldsymbol{D}$, scheme of injection of Cre-dependent AAV expressing SypGFP in $\mathrm{pHB}$ of Sox $14^{\mathrm{Cre} /+}$ mice. E,F,G, representative coronal sections showing the synaptic terminals $\left(\mathrm{GFP}^{+}\right)$of Sox $14^{+}$ 
bioRxiv preprint doi: https://doi.org/10.1101/2022.02.24.481804; this version posted February $25,2022$. The copyright holder for this preprint (which was not certified by peer review) is the author/funder, who has granted bioRxiv a license to display the preprint in perpetuity. It is made available under aCC-BY-NC-ND 4.0 International license.

Brock et al.

pHB neurons in the MH. Most sypGFP positive terminals are within the Calb2 ${ }^{+}$portion of the $\mathrm{MH}(\mathrm{E})$ and antivGAT (G) antibodies in $\mathrm{MH}$, but not with the anti-ChAT antibody (F). Green, SypGFP; magenta, Calb2 (E), ChAT (F), vGAT (G). Scale bar $10 \mu \mathrm{m}$. $\boldsymbol{H}$, scheme for specific ablation of Sox $14^{+} \mathrm{pHB}$ and IGL/LGv neurons using an AAVencoded DTA-expression cassette and behavioural tests' timeline (see also Figure 9-1). I,K, sucrose preference test. Both Sox $14^{+}$pHB- and Sox $14^{+}$IGL/LGv-ablated mice consumed less sucrose solution compared to control subjects. PHB control group: $86.38 \% \pm 1.77 \%$, pHB ablated group: $79.40 \% \pm 2.19 \%, p=0.021$. IGL/LGv control group: $78.84 \% \pm 2.99 \%$, IGL/LGv ablated group: $66.26 \% \pm 4.05 \%, p=0.042$. Data are expressed as mean \pm s.e.m., U-test. J,L, Forced swim test. Both pHB- and IGL/LGv-ablated mice spent more time immobile compared to control subjects. PHB control group: $131.6 \pm 11.39 \mathrm{~s}$, pHB ablated group: $170.1 \pm 6.56 \mathrm{~s}, \mathrm{p}=0.006$. IGL/LGv control group: $114.8 \pm 14.22$ s, IGL/LGv ablated group: $175.1 \pm 10.07$ s, $p=0.002$. Data are expressed as mean \pm s.e.m., U-test.

Mice with ablation of the Sox $14^{+}$neurons of the pHB showed a decreased sucrose preference

(Fig. 9l; $p=0.021$ ) and an increased time spent immobile in the FST (Fig 9J; $p=0.006$ ) compared to control subjects. This finding is consistent with the Sox $14^{+} \mathrm{pHB}$ participating in maintenance of mood tone, potentially acting through their projection to the $\mathrm{MH}$. We then replicated the ablation and behavioural testing strategy for the Sox $14^{+}$neurons of the IGL/LGV to assess whether this would result in a similar change in the SP and the FST, in animals kept under standard single housing conditions. Also in this case, IGL/LGv-ablated mice showed decreased sucrose preference compared to control animals (Fig. 9K; $p=0.042$ ) and spent significantly more time immobile in the FST than control animals (Fig. 9L; $p=0.002$ ). In contrast, anxiety-related behaviour measured as the time spent in the open arms of the elevated-plus maze (EPM) test displayed no significant difference in both pHB- and IGL/LGVablated cohorts ( $\mathrm{pHB}$ control: $33.12 \pm 9.07 \mathrm{~s}, \mathrm{pHB}$ ablation: $27.35 \pm 3.7 \mathrm{~s}, \mathrm{p}=0.598$ and IGL/LGv control: $17.85 \pm 3.53 \mathrm{~s}, \mathrm{IGL} / \mathrm{LGv}$ ablation: $30.7 \pm 7.14 \mathrm{~s}, \mathrm{p}=0.09$, mean \pm s.e.m., t-test). Our observations add to recent work implicating the IGL/LGv (Huang et al., 2019) and the pHB (An et al., 2020; Fernandez et al., 2018) in mood regulation by suggesting that developmentally related Sox $14^{+}$neurons in the IGL/LGv and the pHB regions participate in mood homeostasis. 
bioRxiv preprint doi: https://doi.org/10.1101/2022.02 24.481804 t this version posted February 25,2022 . The copyright holder for this preprint (which was not certified by peer review) is the author/funder, who has granted bioRxiv a license to display the preprint in perpetuity. It is made available under aCC-BY-NC-ND 4.0 International license.

Brock et al.

\section{Discussion}

While the Sox $14^{+}$neurons constitute a thalamic cell class prominently found in the IGL, they also contribute to the prethalamic LGv nucleus and thalamic pHB nucleus. Several fate mapping experiments have demonstrated that LGv neurons arise from prethalamic progenitors (Delaunay et al., 2009; Golding et al., 2014; Inamura et al., 2011; Puelles et al., 2020; Suzuki-Hirano et al., 2011; Vue et al., 2007). Here, we have shown that prethalamic progenitors make a significative contribution to the IGL, a structure of the thalamus proper. The specific circuit organisation of the developmentally defined lineages that make up the IGL/LGv complex is largely unknown. Our monosynaptic restricted retrograde tracing places the Sox $14^{+}$IGL/LGv firmly within the visual system, with input from cortical and subcortical visual structures. Innervation of the Sox $14^{+}$neurons from the cholinergic, monoaminergic and orexinergic neurons appeared more limited, contrasting with previous classic tract tracing experiments of the anatomically defined IGL/LGv complex (Morin, 2013). It would be intriguing to test if input to prethalamic lineages of the IGL/LGv displayed a complementary shift towards the ascending arousal system.

Previous anterograde tracing of retinal input from $O p n 4^{+}$RGCs has provided clear evidence of enriched ipRGC innervation of the IGL/LGv from multiple ipRGC types (Chen et al., 2011) as well as conventional RGC types (Beier et al., 2020). Tracing with an M1-enriched reporter construct identified the IGL, which receives afferents from both the $B r n 3 b^{+}$and the $B r n 3 b^{\text {neg }}$ ipRGCs (Chen et al., 2011), as a major target of the M1 ipRGC subtype (Ecker et al., 2010; Hattar et al., 2006). Surprisingly, our monosynaptic retrograde tracing from Sox $14^{+}$IGL/LGV did not label any M1 ipRGCs, but highlighted input from ipRGC types that express low levels of Opn4 and may be more reliant on classic photoreceptors for luminance detection than the M1 type (Sonoda and Schmidt, 2016). As the vast majority of ipRGCs projecting to the SCN 
bioRxiv preprint doi: https://doi.org/10.1101/2022.02.24.481804; this version posted February 25, 2022. The copyright holder for this preprint (which was not certified by peer review) is the author/funder, who has granted bioRxiv a license to display the preprint in perpetuity. It is made available under aCC-BY-NC-ND 4.0 International license.

Brock et al.

are the Brn3b $b^{\text {neg }}$ M1 type (Baver et al., 2008; Chen et al., 2011), which also participate in innervation of the IGL/LGv (Chen et al., 2011), it is likely that some neurons in the IGL/LGv receive a copy of the SCN's retinal input (Pickard, 1985), however, here we show that the Sox $14^{+}$neurons of the IGL/LGv complex do not participate in such M1-driven circuitry. Intact retinohypothalamic connectivity and preservation of a hypothetical M1 ipRGC driven IGL/LGV tract to the SCN would ensure circadian photoentrainment upon ablation of the Sox $14^{+}$ IGL/LGv, unless the strength of the photic cue is reduced, as observed in our experimental conditions. Our findings are consistent with the hypothesis put forward by Pickard that neurons of the geniculohypothalamic tract may convey information on illumination intensity to the SCN (Pickard et al., 1987). The connectional bias of the Sox $14^{+}$IGL/LGv towards subcortical and cortical visual networks bears implications for the view that integration of photic and non-photic circadian cues takes place in IGL/LGv neurons to provide a unified output to the SCN. Our data could also be compatible with the presence of segregated pathways to the SCN via different subtypes of IGL/LGv neurons, with the prethalamic component of the IGL/LGv a plausible candidate. Under a circadian dim light cycle, the observed high inter-individual variability of the activity onset in Sox $14^{+}$IGL/LGv-ablated mice with or without melanopsin expression, may be explained by the unmasking of one or more Sox $14^{\text {neg }}$ circuitries for internal state-dependent modulation of the circadian clock.

The use of dim light of amplitudes comparable to dusk and dawn carries ethological value, as nocturnal animals in their natural environment are more likely to sample light from a dark burrow and such transient exposure suffice in providing photoentrainment. Indeed, studies on nocturnal flying squirrels (Glaucomys Volans) and other rodents that made use of a den cage, have shown that in nocturnal animals the light sampling behaviour appears to be under circadian control, at dusk and dawn (Pratt and Goldman, 1986; Twente Jr., 1955). It is likely 
bioRxiv preprint doi: https://doi.org/10.1101/2022.02.24.481804; this version posted February 25, 2022. The copyright holder for this preprint (which was not certified by peer review) is the author/funder, who has granted bioRxiv a license to display the preprint in perpetuity. It is made available under aCC-BY-NC-ND 4.0 International license.

Brock et al.

that in their ecological niche nocturnal animals are exposed to just few minutes of light each day (DeCoursey, 1986). Accordingly, regular pulses of light at dusk and dawn are sufficient to photoentrain behavioural rhythms in nocturnal animals (DeCoursey, 1972; Rosenwasser et al., 1983a; Stephan, 1983a). Here we have shown, using an optogenetics strategy, that repeated circadian activation of Sox $14^{+}$neurons in the IGL/LGv interrupts the spontaneous drifting of endogenous activity rhythms in mice kept under constant darkness and results in entrainment of the activity onset, in striking similarity to the effect caused by an analogue optogenetics stimulation of the SCN (Jones et al., 2015; Mazuski et al., 2018).

In nocturnal rodents, acute light exposure causes negative masking of motor activity, a process that involves rapid NREM induction (Lupi et al., 2008; Morin and Studholme, 2009, 2014a; Mrosovsky et al., 2001). The subcortical networks involved in this response to acute light exposure are not fully mapped but are thought to involve the pretectum and superior colliculus (Miller et al., 1998; Zhang et al., 2019). More recently, a genetic strategy to ablate GABAergic neurons in the IGL region resulted in reduced NREM sleep upon acute light presentation in mice (Shi et al., 2019), implicating the IGL/LGv complex as an important node in the phenomenon of photosomnolence. It remained unclear whether the IGL/LGV is also required for vigilance state changes at recurrent and predictable circadian light transitions. IpRGCs, with their connectivity to the SCN, but also directly to other brain regions, play an important role in the control of sleep and arousal (Altimus et al., 2008; Lupi et al., 2008; Muindi et al., 2013; Pilorz et al., 2016; Rupp et al., 2019; Tsai et al., 2009). Circadian light transitions initiate a cascade of events that likely involves multiple brain networks and results in the stabilisation of a new vigilance state. Here, we show that the thalamic Sox $14^{+}$neurons of the IGL/LGv ensure rapid transition to NREM-associated Delta frequency cortical oscillations at lights-on and, conversely, the rapid establishment of a wake cortical profile at 
bioRxiv preprint doi: https://doi.org/10.1101/2022.02 24.481804 t this version posted February 25,2022 . The copyright holder for this preprint (which was not certified by peer review) is the author/funder, who has granted bioRxiv a license to display the preprint in perpetuity. It is made available under aCC-BY-NC-ND 4.0 International license.

Brock et al.

lights-off. Our data substantiate and expand earlier speculative hypotheses implicating the IGL in sleep regulation (Horowitz et al., 2004; Morin, 2013, 2015; Morin and Blanchard, 2005). However, the precise downstream events that are elicited by Sox $14^{+}$IGL/LGv neurons at circadian light transitions remain to be fully elucidated.

Defective encoding of circadian light changes emerges as one of the themes from the cell ablation approach presented here. This is consistent with the failure to photoentrain circadian activity rhythms described in the constitutive Sox14 knockout mice (Delogu et al., 2012); however, while ablation of Sox $14^{+}$IGL/LGv neurons in the mature brain caused delayed transitions in vigilance states at circadian light changes, defective photoentrainment was only detectable under reduced strength of the lighting cues. It is likely that Sox14 loss of function during brain development across neurons of the subcortical visual shell causes widespread changes in network connectivity and neuronal function that result in more overt changes in arousal and circadian behaviours.

In earlier work, we and others demonstrated that during embryonic development, the pTH-R contributes to the formation of a thalamic structure at the edge of the epithalamus (Delogu et al., 2012; Vue et al., 2007) via tangential migration of Sox $14^{+}$neurons from the prospective IGL/LGv (Delogu et al., 2012). Hence, the recently described pHB (An et al., 2020; Fernandez et al., 2018) contains, among other cells, neurons that are developmentally related to the IGL/LGv. The Sox $14^{+}$neurons of the pHB receive a distinctive input from the prefrontal cortex, but lack the prefrontal projections and the nucleus accumbens projections described for other neuronal types of the pHB (An et al., 2020; Fernandez et al., 2018); furthermore, we did not identify an obvious direct retinal input to the Sox $14^{+} \mathrm{pHB}$ neurons, but described instead an input from the IGL/LGv complex, which are themselves innervated by ipRGCs. 
bioRxiv preprint doi: https:/doi org/10.1101/2022.02.24 481804; this version posted February 25,2022 . The copyright holder for this preprint (which was not certified by peer review) is the author/funder, who has granted bioRxiv a license to display the preprint in perpetuity. It is made available under aCC-BY-NC-ND 4.0 International license.

Brock et al.

Concomitantly, we have shown that the Sox $14^{+}$neurons of the pHB present a potential novel pathway for modulation of mood, via a GABAergic input to the dorsal $\mathrm{MH}$.

While the IGL/LGv was recently shown to mediate light-dependent mood control via a direct projection to the LH neurons (Huang et al., 2019), we noted that the dorsal projection of the Sox $14^{+}$IGL/LGv appears to be mostly directed to the $\mathrm{pHB}$ region, consistent with the existence of a novel pathway from the retina to the dorsal MH via the IGL/LGv and pHB. Indeed, ablation of the Sox $14^{+}$neurons in either the IGL/LGv or pHB impaired mood-related behaviour to a similar extent.

By taking a developmentally informed approach, we have identified specific contributions of thalamic neurons of the IGL/LGv and pHB that expand our understanding of thalamic function in sensory perception, the control of vigilance states and the modulation of mood. While this approach reduced the developmental complexity of the anatomically defined IGL/LGv to reveal some of its unique connectional and functional properties, it does not resolve the further differentiation of the Sox $14^{+}$developmental lineage into subsets of molecularly defined mature neurons. Future investigations that exploit single cell genomics and connectomics will reveal the finer grain of parallel and integrated pathways occurring on thalamic projection GABAergic neurons. 
Brock et al.

\section{Materials and Methods}

\section{Animals}

All mice were kept in the animal facilities of King's College London. The Sox $14^{\mathrm{Cre} /+}$ (Jager et al., 2016) (MGI ID: MGI:5909921) and Sox14 ${ }^{\text {GFP/+ }}$ mouse lines (Crone et al., 2008) (MGI ID: 3836003) were maintained in the C57BI/6 background. The Opn4 $4^{\text {taulacz }}$ mouse line (Hattar et al., 2002) (MGI ID: MGI:2449781) was a mixed B6/129 background and was crossed to the Sox $14^{\text {Cre/t }}$ or Sox $14^{\text {GFP/+ }}$ mouse lines. The D/x5/6 $6^{\text {Cre }}$ (Monory et al., 2006) (JAX Stock No: 008199; MGI ID:3758328) and the Rosa26 $6^{\text {Isl-nuclearGFP }}$ (Mo et al., 2015) (JAX Stock No: 021039; MGI ID: 5443817) were maintained in the $\mathrm{C} 57 \mathrm{BI} / 6$ background. Experimental procedures were approved by the Ethical Committee for Animal Use of King's College London and were covered by a Project Licence under the UK Home Office Animals (Scientific Procedures) Act 1986. Mice were kept under normal housing conditions (7am lights on and 7pm lights off, with food and water ad libitum), unless otherwise stated for behavioural experiments. All behavioural experiments were performed on adult ( $>6$ weeks of age) male mice. Tract tracing experiments were performed using animals of both sexes.

\section{Generation of EnvA-pseudotyped, glycoprotein-deleted rabies virus}

The EnvA-pseudotyped, glycoprotein-deleted rabies virus ( $\triangle$ G-SADB19-eGFP, EnvA; abbreviated RVdG) was produced in house following an established protocol (Osakada and Callaway, 2013). The $\triangle$ G-SADB19-eGFP (generous gift from Prof Roska, FMI, Basel, Switzerland) was amplified on BHK-SadGly-GFP cell culture (generous gift from Prof Tripodi, $\mathrm{LMB}$, Cambridge, UK) at $37^{\circ} \mathrm{C}-3.5 \% \mathrm{CO}_{2}$ to slow cell cycle. The BHK-EnvA cell line (generous gift from Prof Tripodi) was used for pseudotyping the virus with EnvA envelope protein (grown at $37^{\circ} \mathrm{C}-5 \% \mathrm{CO}_{2}$ ). Filtered (Steriflip, $0.22 \mathrm{um}$, Millipore) supernatant was stored at $4^{\circ} \mathrm{C}$, 
bioRxiv preprint doi: https://doi.org/10.1101/2022.02 24.481804 t this version posted February 25,2022 . The copyright holder for this preprint (which was not certified by peer review) is the author/funder, who has granted bioRxiv a license to display the preprint in perpetuity. It is made available under aCC-BY-NC-ND 4.0 International license.

Brock et al.

concentrated by ultracentrifugation, resuspended in sterile PBS and stored at $-80^{\circ} \mathrm{C}$ in single use aliquots.

\section{Brain stereotaxic surgeries}

Briefly, mice were placed in a digital stereotaxic frame (World Precision Instruments) under $2.5 \%$ isoflurane anaesthesia. For viral delivery, the skull was exposed by a midline scalp incision, and the stereotaxic frame was aligned using Bregma and Lambda as visual landmarks. A 33-gauge steel needle was placed above the skull and a hole drilled through the skull bone to expose the brain. Virus solutions (100-250 nl) were injected using a borosilicate glass needle (0.58 OD/ID mm, World Precision Instruments) connected to an air injector (Narishige) or a a Nanoject III (Drummond Scientific) injection system. The following general coordinates were used for IGL/LGv with litter-specific finer adjustments: from Bregma AP = $2.25 \mathrm{~mm} ; \mathrm{L}= \pm(2.20-2.40) \mathrm{mm} ; \mathrm{DV}=-2.85 \mathrm{~mm}$; for the pHB from Breagma $A P=-1.6 \mathrm{~mm} ; \mathrm{L}=$ $\pm 0.35 \mathrm{~mm} ; \mathrm{DV}=-(2.42-2.27) \mathrm{mm}) ;$ for $\mathrm{SCN}$ from Bregma AP $=-0.5 \mathrm{~mm} ; \mathrm{L}=0.15 \mathrm{~mm}$; $\mathrm{DV}=-$ (5.0-5.25) $\mathrm{mm}$. The glass needle was left in place for an additional $8 \mathrm{~min}$ before being slowly removed. Following injection, skin was closed using biocompatible tissue glue (VetBond). For optogenetics experiments, two cannulas (200 $\mu \mathrm{m}$ core diameter; Doric Lenses) holding optical fibres were inserted and extended to the ventral edges of the dorsal part of the LGN and further fixed to the skull with dental cement. Mice were allowed to recover in a heating chamber and returned to their home cage after waking up. All mice received a subcutaneous injection with Carprofen $(5 \mathrm{mg} / \mathrm{kg}$ ) for post-operative analgesia.

For in vivo optogenetics experiments, the AAV5-EF1 $\alpha$-DIO-hChR2(H134R)-mCherry (Addgene plasmid \# 37082; Vector Core, University of North Carolina) Control animals received a bilateral injection of a Cre-dependent AAV expressing the cyan fluorescent protein AAV1- 
bioRxiv preprint doi: https://doi.org/10.1101/2022.02 24.481804 t this version posted February 25,2022 . The copyright holder for this preprint (which was not certified by peer review) is the author/funder, who has granted bioRxiv a license to display the preprint in perpetuity. It is made available under aCC-BY-NC-ND 4.0 International license.

Brock et al.

EF1 $\alpha$-DIO-CFP (generated in house). For DTA-mediated cell ablation, the AAV1-EF1 $\alpha-$ mCherry-flex-dta (Adgene plasmid \# 58536 Vector Core, University of North Carolina) was injected bilaterally into the IGL/LGv or the pHB in 3 weeks old Sox $14^{\text {Cre/+}}$ mice. Control animals received a bilateral injection of AAV1- EF1 $\alpha$-DIO-CFP (generated in house).

For monosynaptic tract tracing, we first injected equimolar ratio of AAV1-EF1 $\alpha$-Flex-TVAmCherry (Addgene plasmid \# 38044 Vector Core, University of North Carolina) and AAV1CMV-DIO-oG (codon optimised; Addgene plasmid \# 74290, Vector Core, University of North Carolina) unilaterally in the IGL/LGv or pHB region, followed two weeks later by a second stereotaxic injection of the RV-dG-GFP in the IGL/LGv, SCN or pHB region. Animals were sacrificed 7 days after the RVdG injection.

To identify axonal projections of Sox $14^{+}$pHB neurons the AAV1-EF1 $\alpha$-DIO-mGFP (generated in house) or AAV1-phSyn1(S)-FLEX-tdTomato-T2A-SypEGFP-WPRE (Addgene plasmid \# 51509, generated in house) were injected unilaterally in the pHB region. Animals were perfused 4 weeks later.

\section{Brain immunohistochemistry and RNA in situ hybridisation}

Mice were transcardially perfused with $4 \%$ PFA in PBS and the brains post-fixed at $4{ }^{\circ} \mathrm{C}$ overnight. Brains for ISH were stored in PFA for 5 days, to minimise RNA degradation, and all subsequent solutions were treated with diethyl pyrocarbonate (DEPC; AppliChem). The brains were cryoprotected in a sucrose gradient (10-20-30\%), frozen on dry ice and cut on a cryostat (Leica) at 60 for IHC on floating sections or cryosectioned at $20 \mu \mathrm{m}$ with coronal sections collected on Superfrost Ultra Plus slides (Thermo Scientific) for ISH.

Immunohistochemistry was performed on floating brain sections. Primary antibodies were incubated on sections twice overnight at $4{ }^{\circ} \mathrm{C}$ : chicken anti-GFP (1:10000, Abcam, ab13970), 
bioRxiv preprint doi: https://doi.org/10.1101/2022.02.24.481804; this version posted February 25, 2022. The copyright holder for this preprint (which was not certified by peer review) is the author/funder, who has granted bioRxiv a license to display the preprint in perpetuity. It is made available under aCC-BY-NC-ND 4.0 International license.

Brock et al.

rat anti-RFP (1:1000, 5f8-100, Chromotek), mouse anti-TH (1:1000, MAB5280, Millipore), rabbit anti-calbindin 2 (1:200, ab702, Abcam), rabbit anti-vGAT (1:2000, 131013, Synaptic systems), goat anti-ChAT (1:1000, AB144P, Millipore), mouse anti-TPH (1:50, T0678, SigmaAldrich), goat anti-orexin A (1:1000, sc-8070, Santa Cruz Biotechnology), rabbit c-fos (1:800; ABE457 Sigma), goat anti-orexin B (1:1000, sc-8071, Santa Cruz Biotechnology), rabbit antiMCH (1:1000, H-070-47, Phoenix). Secondary antibodies were incubated on sections for 2 hours at room temperature at a 1:500 dilution. The secondary antibodies used were Alexaconjugated goat anti-chicken Alexa-488 (A11039,ThermoFisher), goat anti-rat Alexa-568 (A11077, Invitrogen), and goat anti-mouse far red (A11036, Invitrogen), donkey anti-goat Alexa-568 (A11057, ThermoFisher), donkey anti-chicken Alexa-488 (703-545-155, Jackson ImmunoReasearch), donkey anti-mouse far red (ab150107, Millipore), donkey anti-rabbit Alexa-647 (A31573, Invitrogen), donkey anti-rat Alexa-568 (Invitrogen). Blocking and antibody binding solutions where $7 \%$ goat serum/PBS with $0.3 \%$ TritonX-100 or $3-10 \%$ donkey serum/PBS with $1 \%$ BSA and $0.5 \%$ TritonX-100 as blocking solution. After DAPI staining (1:40000 in 1X PBS; Life Technologies) the sections were mounted on Menzel-Glasser Superfrost Plus (J1800AMNZ, ThermoScientific) glass slides using the ProLong Gold antifade reagent (P36930, Invitrogen) mounting medium.

In situ hybridisation (ISH) was performed with a Npy antisense RNA probe transcribed in vitro from a cDNA template (IMAGE ID: 5683102). The probe was diluted to a final concentration of $800 \mathrm{ng} / \mathrm{ml}$ in hybridization buffer ( $50 \%$ formamide, $10 \%$ dextran sulphate, $1 \mathrm{mg} / \mathrm{ml} \mathrm{rRNA}$, 1X Denhardt's solution, $0.2 \mathrm{M} \mathrm{NaCl}, 10 \mathrm{mM}$ Tris $\mathrm{HCl}, 5 \mathrm{mM} \mathrm{NaH} 2 \mathrm{PO} 4.2 \mathrm{H} 2 \mathrm{O}, 1 \mathrm{mM}$ Tris base, 50mM EDTA) and applied onto the slides, which were incubated in a humidified chamber at $65^{\circ} \mathrm{C}$ overnight. The slides were then washed three times for $30 \mathrm{~min}$ in wash buffer $(50 \%$ formamide, $1 \mathrm{XSSC}, 0.1 \%$ Tween) at $65^{\circ} \mathrm{C}$, two times for $30 \mathrm{~min}$ in MABT buffer ( $100 \mathrm{mM}$ maleic 
bioRxiv preprint doi: https://doi.org/10.1101/2022.02.24.481804 t this version posted February 25, 2022. The copyright holder for this preprint (which was not certified by peer review) is the author/funder, who has granted bioRxiv a license to display the preprint in perpetuity. It is made available under aCC-BY-NC-ND 4.0 International license.

Brock et al.

acid, $150 \mathrm{mM} \mathrm{NaCl}, 0.1 \%$ Tween-20) at RT, and blocked for $2 \mathrm{~h}$ at RT (2\% Boehringer Blocking Reagent (Roche), 20\% inactivated sheep serum in MABT). Sheep a-DIG alkaline phosphatase conjugated antibody (Roche, 11093274910) was diluted 1:2000 in the blocking solution and incubated with the slides overnight at $4^{\circ} \mathrm{C}$. This was followed by five $20 \mathrm{~min}$ washes in MABT and two $20 \mathrm{~min}$ washes in the AP buffer (100mM Tris- $\mathrm{HCl}$ pH9.5, $100 \mathrm{mM} \mathrm{NaCl}, 50 \mathrm{mM} \mathrm{MgCl}$, 0.1\%-Tween-20). NBT/BCIP (Sigma) was diluted in the AP buffer and applied onto the slides for colour reaction for 3-6 hours at RT in the dark.

\section{Retina immunohistochemistry}

The eyes were dissected, post-fixed in 4\% PFA overnight, and washed for at least 1 day in PBS at $4^{\circ} \mathrm{C}$. The retinas were then dissected in ice cold PBS and washed again in PBS at $4^{\circ} \mathrm{C}$. The retinas were then blocked in $10 \%$ normal donkey serum, $1 \%$ bovine serum albumin (BSA), 0.5\% TritonX-100 in PBS for $1 \mathrm{~h}$ at RT. The following primary antibodies were used: goat antiChAT, 1:200 (Chemicon, AB144P); chicken anti-GFP, 1:5000 (Abcam, ab13970); rabbit antiOpn4, 1:5000 (Advanced Targeting Systems, AB-N38, AB-N39); rabbit anti-UV cone opsin, 1:200 (Millipore, AB5407). The antibodies were diluted in 3\% normal donkey serum, $1 \%$ BSA, $0.02 \%$ sodium azide, $0.5 \%$ TritonX-100 in PBS). The retinas were incubated in primary antibodies for 7 days at RT on a shaker. This was followed by three PBS washes, each for 30 min. The secondary antibodies used were donkey anti-goat AlexaFluor 633, 1:500 (ThermoFisher, A21082), donkey anti-goat AlexaFluor 647 (Invitrogen, A21447), donkey antirabbit AlexaFluor 568, 1:500 (Invitrogen, A10042) and donkey anti-chicken AlexaFluor 488, 1:500 (Jackson ImmunoReasearch, 703-545-155), diluted in 3\% NDS, and incubated with the retinas for 1 day at $4^{\circ} \mathrm{C}$. The next day, there were two 30 min PBS washes, followed by incubation in DAPI (1:40000 in PBS; Life Technologies) overnight at $4^{\circ} \mathrm{C}$. The retinas were then 
bioRxiv preprint doi: https://doi.org/10.1101/2022.02 24.481804 t this version posted February 25,2022 . The copyright holder for this preprint (which was not certified by peer review) is the author/funder, who has granted bioRxiv a license to display the preprint in perpetuity. It is made available under aCC-BY-NC-ND 4.0 International license.

Brock et al.

changed to PBS and mounted, using the ProLong Diamond mounting medium (Invitrogen). Spacers (SLS, $24 \times 24 \mathrm{~mm}$, no.15) were used on the slides to prevent the coverslips compressing the retinas.

\section{Optogenetic stimulation}

Animals were chronically tethered to a branching fibreoptic patch cord (200 $\mu \mathrm{m}$ diameter core, 0.53 NA; Doric Lenses) attached to the implanted cannula and connected to a highpowered blue $(470 \mathrm{~nm}$ ) LED (Doric Lenses) under the control of an LED Driver (LEDRVP-2CH, Doric Lenses). LED source and patch cord were connected via an optical rotary joint allowing free movements of the animal in a circular cage. Mice were kept in constant darkness and allowed to free run at least a week before stimulation. Locomotor activity was monitored in 1 min bins using Clocklab software (Actimetrics, Inc, Wilmette, IL, USA). Light pulses (470 nm, $8 \mathrm{~Hz}, 10$ ms duration, 1h) were generated approximately 3 hours or 6 hours after the onset of the active phase, through Doric Neuroscience Studio software (Doric Lenses) and repeated daily at the same clock time over 14 days. Light intensity at the cannula tip was determined to be $4.5 \mathrm{mV}$ when driven at $1000 \mathrm{~mA}$ using a PM100D Optical Power Meter (Thorlabs).

\section{Light exposure protocol}

Mice were single-housed in a circadian light-, air-, temperature-controlled ventilated cabinet (Phenome Technologies) monitored by Clocklab Chamber Control Software (Actimetrics, Inc, Wilmette, IL, USA). Mice were first entrained to $12 \mathrm{~h}: 12 \mathrm{~h}$ light dark cycle under standard light intensity (200 lux). Then, all subjects went through a "jet-lag" paradigm ( $6 \mathrm{~h}$ phase advance) using bright light (200 lux) lasting 14 days. Mice were then housed in constant darkness for 14 days and free running was assessed. Following these light conditions, mice 
bioRxiv preprint doi: https://doi.org/10.1101/2022.02 24.481804; this version posted February 25, 2022. The copyright holder for this preprint (which was not certified by peer review) is the author/funder, who has granted bioRxiv a license to display the preprint in perpetuity. It is made available under aCC-BY-NC-ND 4.0 International license.

Brock et al.

were allowed to re-entrained to $12 \mathrm{~h}: 12 \mathrm{~h}$ light dark cycle under bright light (200 lux) for 2 weeks before going through a novel "jet-lag" paradigm (6 h phase advance) using dim light (10 lux) lasting 14 days. General activity was measured by using infrared motion sensors (Actimetrics, Inc, Wilmette, IL, USA) wired to a computer. Data were collected in 1-min bins using Clocklab software (Actimetrics, Inc, Wilmette, IL, USA).

\section{Behavioural tests}

Sucrose anhedonia. Adult mice (approx. 9 months old) were single housed in the presence of two water bottles 1 day before testing to acclimate them to the bottles. Sucrose preference was assessed over 2 days. On the first day, one bottle containing $1 \%$ sucrose and one bottle containing water were introduced at the beginning of the active phase $(7 \mathrm{pm})$. Bottles were removed at the end of the active phase (7am). On the second day, the position of the two bottles was switched and the procedure repeated. Bottles were weighed at the beginning and end of the active period to measure amount consumed as well as mice and food to detect any abnormal change in food consumption. Sucrose preference was calculated by dividing the amount of sucrose consumed by the total amount consumed (water and sucrose). The percentage of sucrose consumed by control and ablated mice was compared by the Mann Whitney $U$ test.

Forced swim test. Adult mice (approx. 9 months old) were individually placed in an inescapable clear Perspex cylinder (49 cm high x $15 \mathrm{~cm}$ diameter), filled with $40 \mathrm{~cm}$ of water at $25^{\circ} \mathrm{C}$. Mice were carefully placed in the water and left to swim for $6 \mathrm{~min}$. Behaviour was monitored by a video camera positioned in front of the apparatus and scored manually through Ethovision software (Noldus). Time spent immobile for the last 4 min of the test was calculated. Increased time spent immobile is indicative of increased depression-related 
Brock et al.

behaviour. The amount of time spent immobile during the last 4 min was analysed by the Mann Whitney $U$ test.between control and ablated mice.

Elevated-plus maze. The apparatus consisted of two open arms ( $30 \times 5 \mathrm{~cm}$ ) opposite to one another and two arms enclosed by opaque walls $(30 \times 5 \times 15 \mathrm{~cm})$ opposite of one another forming a cross. The arms were separated by a central platform $(5 \times 5 \mathrm{~cm})$. The maze was elevated $(40 \mathrm{~cm})$ such that the open arms are aversive due to openness, unfamiliarity and elevation. The light intensity in the open arms was 200 lux, whereas the light intensity in the closed arms was 10 lux. Mice were placed in the centre of the elevated plus maze facing one of the open arms and allowed to freely move around the maze for $5 \mathrm{~min}$. Behaviour was monitored from above by a video camera connected to Ethovison video tracking system (Noldus). The apparatus was cleaned thoroughly between each trial. The time spent and the distance travelled in the open arms were measured as indications of anxiety-related behaviour. These measures were compared between control and ablated mice using Student's unpaired t-test.

\section{Sleep recording}

Adult mice (approx. 6 months old) were chronically implanted with screw-type electrodes in the skull to measure cortical EEG. A pair of stainless-steel electrodes was implanted in the dorsal neck muscle to measure EMG. Screw electrodes were placed in burr holes in the skull over the parietal cortex $(-1.5 \mathrm{~mm}$ Bregma, $+1.5 \mathrm{~mm}$ midline $)$ and frontal cortex $(+1.5 \mathrm{~mm}$ Bregma, $-1.5 \mathrm{~mm}$ midline) with a reference electrode over the cerebellum (1.0 $\mathrm{mm}$ caudal to lambda, $0 \mathrm{~mm}$ midline) and a ground over the olfactory bulb area. 
bioRxiv preprint doi: https://doi.org/10.1101/2022.02 24.481804 t this version posted February 25, 2022. The copyright holder for this preprint (which was not certified by peer review) is the author/funder, who has granted bioRxiv a license to display the preprint in perpetuity. It is made available under aCC-BY-NC-ND 4.0 International license.

Brock et al.

Electrodes were connected to head-mounts and secured with dental cement. The animals were allowed to recover from surgery for at least one week, before the EEG/EMG recordings were performed.

At the time of the recordings, mice were tethered to four channel EEG/EMG recording systems (Pinnacle Technology Inc.) and housed individually and sequentially in a soundproof and light-controlled cabinet (standard light conditions 200 lux) equipped with a videocamera with a $3.6 \mathrm{~mm}$ lens and infrared illumination (Pinnacle Technology $\mathrm{Inc}$ ). Data was acquired continuously for a 48-hour period, maintaining the same light-dark cycle, temperature and humidity as for the home cages. The EEG/EMG signals were sampled at $250 \mathrm{~Hz}$, amplified 100x and low-pass filtered at $100 \mathrm{~Hz}$ using a two EEG channel, two EMG channel mouse preamplifier (Pinnacle Technology Inc).

Sleep scoring was performed manually on 10 -second epochs using Sirenia Sleep software (Pinnacle Technology Inc.). EEG and EMG recordings were synchronized for each epoch to video recordings. Epochs with EMG amplitude slightly (quiet WAKE) or significantly higher than baseline (active WAKE), together with desynchronized low amplitude EEG were scored as "WAKE". Epochs with low-amplitude EMG and high amplitude delta (1-4 Hz) activity were scored as "NREM" and epochs with low amplitude EMG accompanied by low-amplitude rhythmic theta activity (6-9 Hz) were recorded as "REM" (Quattrocchi et al., 2015).

Distance travelled and velocity were extracted from video files at $30 \mathrm{fps}$ and synchronized with the EEG and EMG data for each individual mouse, using the Sirenia software video plugin (Pinnacle Technology, Inc).

Electrophysiology on acute brain slices 
bioRxiv preprint doi: https://doi.org/10.1101/2022.02.24.481804; this version posted February 25, 2022. The copyright holder for this preprint (which was not certified by peer review) is the author/funder, who has granted bioRxiv a license to display the preprint in perpetuity. It is made available under aCC-BY-NC-ND 4.0 International license.

Brock et al.

Animals were culled in accordance with the UK Home Office guidelines. Brains were rapidly removed from the skull and immediately immersed in ice cold slicing solution (92 mM NMDG, $2.5 \mathrm{mM} \mathrm{KCl}, 1.25 \mathrm{mM}$ NaH2PO4, $30 \mathrm{mM} \mathrm{NaHCO}, 20 \mathrm{mM}$ HEPES, 25 mM glucose, $2 \mathrm{mM}$ thiourea, $5 \mathrm{mM}$ Na-ascorbate, $3 \mathrm{mM}$ Na-pyruvate, $0.5 \mathrm{mM} \mathrm{CaCl} \cdot 4 \mathrm{H} 2 \mathrm{O}$ and $10 \mathrm{mM}$ MgSO4.7H2O), $\mathrm{pH}$ 7.3-7.4 when bubbled with 95\%O2/5\%CO2). Slices were cut using a vibratome tissue slicer (Campden instruments) at a thickness of $300 \mu \mathrm{m}$, after which they were immediately transferred to a holding chamber containing slicing NMDG at $33-34^{\circ} \mathrm{C}$ continuously bubbled with $95 \% \mathrm{O} 2 / 5 \% \mathrm{CO} 2$. Slices were left to equilibrate for 10-15 minutes, after which they were transferred into a holding chamber at room temperature containing recording ACSF (125 mM NaCl, $2.5 \mathrm{mM} \mathrm{KCl}, \mathrm{CaCl} 22 \mathrm{mM}, 1 \mathrm{mM} \mathrm{MgCl}, 1.25 \mathrm{mM} \mathrm{NaH} 2 \mathrm{PO} 4,26$ $\mathrm{mM} \mathrm{NaHCO3,} 11 \mathrm{mM}$ glucose, $\mathrm{pH} 7.4$ ) that was continuously bubbled with $95 \% \mathrm{O} 2 / 5 \% \mathrm{CO} 2$. Slices were then visualized using a fixed-stage upright microscope (BX51W1, Olympus and Scientifica Slice scope) fitted with a high numerical aperture water-immersion objective and an infra-red sensitive digital camera. A 595nm amber LED was used for identifying mCherry expression and a 470nm blue LED was used for optogenetics stimulation. Patch pipettes were made from thick-walled borosilicate glass capillaries $(0.86 \mathrm{~mm}$ internal diameter, $1.5 \mathrm{~mm}$ outer diameter, Harvard Apparatus) using a two-step vertical puller (Narishige, PC-10). Pipette resistances were typically 5-8 $\mathrm{M} \Omega$ when back filled with internal solution. For voltageclamp experiments, the internal solution contained: $140 \mathrm{mM} \mathrm{CsCl}, 4 \mathrm{NaCl} \mathrm{mM}, 0.5 \mathrm{mM} \mathrm{CaCl}$, $10 \mathrm{mM}$ HEPES, $5 \mathrm{mM}$ EGTA, $2 \mathrm{Mg}$-ATP mM; and the $\mathrm{pH}$ was adjusted to 7.3 with CsOH. For current-clamp experiments the internal solution contained: $145 \mathrm{mM} \mathrm{K-gluconate;} 4 \mathrm{mM} \mathrm{NaCl}$; $0.5 \mathrm{mM} \mathrm{CaCl}$; $10 \mathrm{mM}$ HEPES; 5 mM EGTA; 4 mM Mg-ATP; $0.3 \mathrm{mM}$ Na-GTP (adjusted to $\mathrm{pH}$ 7.3 with $\mathrm{KOH})$. The amplifier head stage was connected to an Axopatch $700 \mathrm{~B}$ amplifier (Molecular Devices; Foster City, CA). 
bioRxiv preprint doi: https://doi.org/10.1101/2022.02 24.481804 t this version posted February 25, 2022. The copyright holder for this preprint (which was not certified by peer review) is the author/funder, who has granted bioRxiv a license to display the preprint in perpetuity. It is made available under aCC-BY-NC-ND 4.0 International license.

Brock et al.

The amplifier current output was filtered at $10 \mathrm{kHz}(-3 \mathrm{~dB}, 8$-pole low-pass Bessel) and digitized at $20 \mathrm{kHz}$ using a National Instruments digitization board (NI-DAQmx, PCl-6052E; National Instruments, Austin, Texas). Data acquisition was performed using CED Signal (Version 6) software. CED Signal's “IntraSpikeAnalysis" spike detection script was used for Current Clamp action potential detection thresholding at $0 \mathrm{mV}$. WinEDR (Strathclyde Electrophysiology Software) was used for Voltage Clamp postsynaptic current detection through template fitting at $0.1 \mathrm{~ms}$ (Tau Rise) \& $10 \mathrm{~ms}$ (Tau Decay).

For Peristimulus Time Histogram (PSTH), an in-house MATLAB code (https://github.com/dd119-ic/BrockManuscript) was used to construct PSTHs from the optogenetic input timings and detected events. OriginPro v2020 was used to construct histograms and for power spectrum analysis.

\section{QUANTIFICATION AND STATISTICAL ANALYSIS}

\section{Monosynaptic viral tracing}

Nikon A1R Inverted or Nikon Upright Ni-E confocal optics were used to acquire images using a 20X/NA 0.75 Plan Apo VC or a 60X/1.4NA objective. Data on starter cells were collected by analysing z-stack images of all coronal sections spanning the entire injection site, acquired with A1R Nikon confocal microscopes, using the 'multipoint' function in Fiji (Schindelin et al., 2012). Mono-synaptic inputs were calculated as percent of total for each brain or normalised per starter cell, using Excel 365 (Microsoft) and GraphPad Prism 8 software.

The location and distribution of transynaptically labelled neurons across the brain was assessed using a Zeiss Axiolmager microscope using the 4X/0.10 Acroplan and 10X/0.3 Ph1 EC-Plan-NeoFluar objectives. Regions where the $\mathrm{GFP}^{+}$somas were present were identified by comparison with the Paxinos \& Franklin Mouse Brain Atlas. The Zeiss Axiolmager microscope 
bioRxiv preprint doi: https://doi.org/10.1101/2022.02 24.481804 t this version posted February 25,2022 . The copyright holder for this preprint (which was not certified by peer review) is the author/funder, who has granted bioRxiv a license to display the preprint in perpetuity. It is made available under aCC-BY-NC-ND 4.0 International license.

Brock et al.

was also used to acquire overviews of coronal sections showing the brain-wide distribution of inputs, using a Plan NeoFluar 2.5X/0,075 objective.

\section{RGC analysis}

A Nikon A1R confocal microscope was used to acquire z-stacks (step size $1.1 \mu \mathrm{m}$ ) of the RGCs using the 20X/NA 0.75 Plan Apo VC objective. The stacks were acquired such that both ON and OFF ChAT ${ }^{+}$layers and the entire extent of the RGC's dendrites were included. Overviews of the retinas were acquired using a 10X/NA 0.3 Plan Fluor D objective and images were acquired as z-stacks (step size: $10 \mu \mathrm{m}$ ) and were composed of $4 \times 4$ tiles.

RGC dendritic arbour tracing and annotation of ChAT layers was based on the protocol published in (Sumbul et al., 2014). The RGC dendritic trees were traced manually using the Simple Neurite Tracer plugin (Longair et al., 2011) and SNT plugin in Fiji (Schindelin et al., 2012) and exported as .swc files. To annotate the ChAT layers, the z-stack images were first resliced so that the z-dimension was projected onto the $y$-axis. The ON ChAT layer was manually annotated, using the 'multipoint' function in Fiji, and every 80th digital slice was marked with 5-10 data points. The $\mathrm{x}, \mathrm{y}$ and $\mathrm{z}$ coordinates for all the points were exported as a .txt file. The procedure was then repeated for the OFF ChAT layer. Opn4 expression levels in RVdG-infected RGCs was compared with the stronger signal from putative M1 ipRGCs and the background signal in the RGC layer, within the same image frame.

RVdG-labelled Opn4 ${ }^{+}$RGCs were analysed using a MATLAB implementation of the algorithm developed by (Sumbul et al., 2014) and available at https://github.com/padraic-padraic/rgc. The algorithm begins by 'unwarping' the ChAT layers, to produce two flat planes corresponding to the ON and OFF layers. The program then quantifies the arbour density in the IPL relative to these layers, outputting a histogram of arbour density against the IPL z-axis, 
bioRxiv preprint doi: https://doi.org/10.1101/2022.02.24.481804; this version posted February 25, 2022. The copyright holder for this preprint (which was not certified by peer review) is the author/funder, who has granted bioRxiv a license to display the preprint in perpetuity. It is made available under aCC-BY-NC-ND 4.0 International license.

Brock et al.

where $z=0 \mu \mathrm{m}$ corresponds to the ON layer and $z=12 \mu \mathrm{m}$ corresponds to the OFF layer. The stratification data was then processed further, based on (Siegert et al., 2009) and (Rompani et al., 2017). In particular, the IPL was divided into 10 layers, which were defined such that the OFF ChAT layer is contained in strata 3, and the ON layer in strata 7. The remaining layers were defined by linearly interpolating the spacing between the ON and OFF ChAT layers and extending this interpolation to produce 10 full strata corresponding to $3 \mu \mathrm{m}$ each. The dendritic arbour density histogram was then binned into each of these 10 strata using our custom MATLAB script (https://github.com/padraic-padraic/rgc). Each bin contained the summed arbour density within its range. Stratification above and below the 'boxed' region was included in bins 1 and 10, respectively. A stratum was considered 'labelled' if the total arbour density in that bin was greater than the average density across all bins. This strata labelling was used to output boxplots of stratification. Cells were then classified into ON, OFF or ON-OFF stratifying using the labelled stratum. ON stratifying cells had only stratum in bins 6-10 labelled. OFF stratifying cells had only stratum bins 1-5 labelled. Lastly, ON-OFF stratifying cells had either stratum labelled from stratum bins 1-5 and 6-10 or were seen to have clear peaks in ranges corresponding to both ON and OFF stratum bins from raw stratification output.

The diameter of the dendritic arbour was quantified using our custom MATLAB script (https://github.com/urygarsumbul/rgc), based on the skeletonized arbour. The output .swc file contains a description of the arbour as 'nodes' connected by 'edges'. The ends of the dendritic arbor were identified as all nodes connected to only a single edge. Their $\mathrm{x}$ and y coordinates were converted to physical distances from the centre of the image by multiplying them with the corresponding voxel resolutions in $\mu \mathrm{m}$. Using the MATLAB 'pdist' routine, the Euclidian distance between every pair of end-nodes was calculated, and the maximum value 
bioRxiv preprint doi: https://doi.org/10.1101/2022.02 24.481804 t this version posted February 25,2022 . The copyright holder for this preprint (which was not certified by peer review) is the author/funder, who has granted bioRxiv a license to display the preprint in perpetuity. It is made available under aCC-BY-NC-ND 4.0 International license.

Brock et al.

was taken as the dendritic diameter. Scholl analysis and measurements of total branching points and total dendritic length were performed using the SNT plugin for FIJI. Total branching points and total dendritic length were measured using SNTs in-built measurement functions for cable length and number of branch points. In Scholl analysis a pixel central to the nucleus of RGCs was chosen as a starting point and radius step size was set to $10 \mu \mathrm{m}$. Statistical comparisons of morphological parameters from ON, OFF and ON-OFF stratifying cell groups were made with Kruskal-Wallis tests followed by Dunn's multiple comparisons tests.

\section{Behavioural data analysis}

Investigators were blinded to the group allocation during experiments or data analysis. Sample sizes were indicated in the figures and associated text and are similar to those reported in previous studies (An et al., 2020; Huang et al., 2019). Data were analysed using the GraphPad Prism 8 software. For all statistical comparisons, we first analysed the data distribution with the Shapiro-Wilk test and D'Agostino-Pearson test for normality. Statistical differences of normally distributed data were then determined using unpaired two-tailed $t$ test. The Mann-Whitney $U$ test was employed to analyse non-normally distributed data. $P$ values less than 0.05 were considered significant and the thresholds for $P$ value significance were reported as follows: ${ }^{*} P<0.05 ;{ }^{* *} P \leq 0.01 ;{ }^{* *} P \leq 0.001 ; * * * * P \leq 0.0001$. Experimental errors are presented as standard error of the mean (s.e.m.).

\section{EEG/EMG Data Analysis}

Cumulative power in alpha $(8-12 \mathrm{~Hz})$, delta $(0.5-4 \mathrm{~Hz})$ and theta $(6-9 \mathrm{~Hz})$ frequency bands were calculated by computing the discrete Fourier transform (DFT) of the EEG data using a fast Fourier transform (FFT) algorithm. Then, the summed power in each frequency band was 
bioRxiv preprint doi: https://doi.org/10.1101/2022.02 24.481804; this version posted February 25, 2022. The copyright holder for this preprint (which was not certified by peer review) is the author/funder, who has granted bioRxiv a license to display the preprint in perpetuity. It is made available under aCC-BY-NC-ND 4.0 International license.

Brock et al.

normalised to the sum of the power over the entire range $(0-15 \mathrm{~Hz})$. Power Spectral Density (PSD) estimates were calculated using Welch method ( window length = 1000; NFFT = 1024). Spectograms showing the amplitude of EEG signals in the time and frequency domain were generated using Short-time Fourier transform (window length $=1024$; NFFT $=4096$ ), as previously described (Zhivomirov, 2019). Theta/Delta and Delta/Theta ratios were calculated by summing PSD values for each frequency range and dividing by each other. EEG signal analyses were conducted using custom codes written in MATLAB, as previously described (Gelegen et al., 2014; Gelegen et al., 2018; Pang et al., 2009; Zhivomirov, 2019).

EEG/EMG statistical analysis: All statistical tests were performed in GraphPad Prism 8. Shapiro-Wilk test was used for normality of distribution. Data are represented as the mean \pm s.e.m., unless otherwise stated. Time spent at each vigilance state, Theta/Delta and Delta/Theta ratios for the hour preceding and following the circadian light change was compared between the two groups using paired t-test or Wilcoxon test, depending on the normality of the data. Normalized power at Alpha, Delta and Theta frequency bands for the hour preceding and two hours following the circadian light change were compared between the groups first using repeated measures One Way ANOVA or Friedman Test depending on the normality of the data. If a significant overall $p$ value was obtained, individual time points were compared using paired t-test or Wilcoxon test.

\section{Code availability}

The code for RGC analysis generated during this study is available at GitHub https://github.com/padraic-padraic/rgc.

The code for Peristimulus Time Histogram (PSTH) is available at GitHub 
bioRxiv preprint doi: https://doi.org/10.1101/2022.02.24.481804; this version posted February 25, 2022. The copyright holder for this preprint (which was not certified by peer review) is the author/funder, who has granted bioRxiv a license to display the preprint in perpetuity. It is made available under aCC-BY-NC-ND 4.0 International license.

Brock et al.

https://github.com/dd119-ic/BrockManuscript 
bioRxiv preprint doi: https://doi.org/10.1101/2022.02 24.481804; this version posted February 25, 2022. The copyright holder for this preprint (which was not certified by peer review) is the author/funder, who has granted bioRxiv a license to display the preprint in perpetuity. It is made available under aCC-BY-NC-ND 4.0 International license.

Brock et al.

\section{Acknowledgments}

We are grateful to Nicola Maiorano, Kamill Balint, Botond Roska at the Friedrich Miescher Institute (FMI, CH) and Marco Tripodi MRC Laboratory of Molecular Biology (LMB, University of Cambridge, UK) for reagents and protocols for recombinant rabies virus production. We are grateful to Samer Hattar (NIH, US) for the gift of the Opn4taulacZ mouse line. We thank Padraic Calpin (University College London, UK) for designing the MATLAB code to analyse RGCs. We thank Vladyslav Vyazovskiy (University of Oxford, UK) for advice on EEG/EMG recordings in mice. We thank the Wohl Cellular Imaging Centre (WCIC) at Kings College London for help with microscopy. This work was funded by a Royal Society grant RG160741 and Biotechnology and Biological Sciences Research Council (BBSRC) BB/L020068/1 and BB/R007020/1 grants to AD. OB was the recipient of an Independent Research Award by the Institute of Psychiatry, Psychology and Neuroscience, King's College London.

\section{Conflict of interest statement}

The authors declare to have no conflicts of interest or financial interests associated with the research presented in this manuscript. 
bioRxiv preprint doi: https://doi.org/10.1101/2022.02 24.481804 this version posted February 25,2022 . The copyright holder for this preprint (which was not certified by peer review) is the author/funder, who has granted bioRxiv a license to display the preprint in perpetuity. It is made available under aCC-BY-NC-ND 4.0 International license.

Brock et al.

\section{References}

Altimus, C.M., Guler, A.D., Villa, K.L., McNeill, D.S., Legates, T.A., and Hattar, S. (2008). Rodscones and melanopsin detect light and dark to modulate sleep independent of image formation. Proc Natl Acad Sci U S A 105, 19998-20003.

An, K., Zhao, H., Miao, Y., Xu, Q., Li, Y.F., Ma, Y.Q., Shi, Y.M., Shen, J.W., Meng, J.J., Yao, Y.G., et al. (2020). A circadian rhythm-gated subcortical pathway for nighttime-light-induced depressive-like behaviors in mice. Nat Neurosci.

Baver, S.B., Pickard, G.E., Sollars, P.J., and Pickard, G.E. (2008). Two types of melanopsin retinal ganglion cell differentially innervate the hypothalamic suprachiasmatic nucleus and the olivary pretectal nucleus. Eur J Neurosci 27, 1763-1770.

Beier, C., Zhang, Z., Yurgel, M., and Hattar, S. (2020). The projections of ipRGCs and conventional RGCs to retinorecipient brain nuclei. bioRxiv.

Berson, D.M., Castrucci, A.M., and Provencio, I. (2010). Morphology and mosaics of melanopsin-expressing retinal ganglion cell types in mice. J Comp Neurol 518, 2405-2422.

Blasiak, T., and Lewandowski, M.H. (2003). Dorsal raphe nucleus modulates neuronal activity in rat intergeniculate leaflet. Behav Brain Res 138, 179-185.

Brown, T.M., Gias, C., Hatori, M., Keding, S.R., Semo, M., Coffey, P.J., Gigg, J., Piggins, H.D., Panda, S., and Lucas, R.J. (2010). Melanopsin contributions to irradiance coding in the thalamo-cortical visual system. PLoS Biol 8, e1000558.

Chen, S.K., Badea, T.C., and Hattar, S. (2011). Photoentrainment and pupillary light reflex are mediated by distinct populations of ipRGCs. Nature 476, 92-95.

Cheng, H.Y., Obrietan, K., Cain, S.W., Lee, B.Y., Agostino, P.V., Joza, N.A., Harrington, M.E., Ralph, M.R., and Penninger, J.M. (2004). Dexras1 potentiates photic and suppresses nonphotic responses of the circadian clock. Neuron 43, 715-728. 
bioRxiv preprint doi: https://doi.org/10.1101/2022.02 24.481804 t this version posted February 25,2022 . The copyright holder for this preprint (which was not certified by peer review) is the author/funder, who has granted bioRxiv a license to display the preprint in perpetuity. It is made available under aCC-BY-NC-ND 4.0 International license.

Brock et al.

Chrobok, L., Jeczmien-Lazur, J.S., Pradel, K., Klich, J.D., Bubka, M., Wojcik, M., Kepczynski, M., and Lewandowski, M.H. (2021). Circadian actions of orexins on the retinorecipient lateral geniculate complex in rat. J Physiol 599, 231-252.

Chrobok, L., Palus-Chramiec, K., Jeczmien-Lazur, J.S., Blasiak, T., and Lewandowski, M.H. (2018). Gamma and infra-slow oscillations shape neuronal firing in the rat subcortical visual system. J Physiol 596, 2229-2250.

Crone, S.A., Quinlan, K.A., Zagoraiou, L., Droho, S., Restrepo, C.E., Lundfald, L., Endo, T., Setlak, J., Jessell, T.M., Kiehn, O., et al. (2008). Genetic ablation of V2a ipsilateral interneurons disrupts left-right locomotor coordination in mammalian spinal cord. Neuron 60, 70-83.

DeCoursey, P.J. (1972). LD ratios and the entrainment of circadian activity in a nocturnal and a diurnal rodent. Journal of comparative physiology 78, 221-235.

DeCoursey, P.J. (1986). Light-sampling behavior in photoentrainment of a rodent circadian rhythm. J Comp Physiol A 159, 161-169.

Delaunay, D., Heydon, K., Miguez, A., Schwab, M., Nave, K.A., Thomas, J.L., Spassky, N., Martinez, S., and Zalc, B. (2009). Genetic tracing of subpopulation neurons in the prethalamus of mice (Mus musculus). J Comp Neurol 512, 74-83.

Delogu, A., Sellers, K., Zagoraiou, L., Bocianowska-Zbrog, A., Mandal, S., Guimera, J., Rubenstein, J.L., Sugden, D., Jessell, T., and Lumsden, A. (2012a). Subcortical visual shell nuclei targeted by ipRGCs develop from a Sox14+-GABAergic progenitor and require Sox14 to regulate daily activity rhythms. Neuron $75,648-662$.

Dhande, O.S., Stafford, B.K., Franke, K., El-Danaf, R., Percival, K.A., Phan, A.H., Li, P., Hansen, B.J., Nguyen, P.L., Berens, P., et al. (2019). Molecular Fingerprinting of On-Off DirectionSelective Retinal Ganglion Cells Across Species and Relevance to Primate Visual Circuits. J Neurosci 39, 78-95. 
Brock et al.

Dragunow, M., and Faull, R. (1989). The use of c-fos as a metabolic marker in neuronal pathway tracing. J Neurosci Methods 29, 261-265.

Ecker, J.L., Dumitrescu, O.N., Wong, K.Y., Alam, N.M., Chen, S.K., LeGates, T., Renna, J.M., Prusky, G.T., Berson, D.M., and Hattar, S. (2010). Melanopsin-expressing retinal ganglion-cell photoreceptors: cellular diversity and role in pattern vision. Neuron 67, 49-60.

Edelstein, K., and Amir, S. (1999). The role of the intergeniculate leaflet in entrainment of circadian rhythms to a skeleton photoperiod. J Neurosci 19, 372-380.

Estevez, M.E., Fogerson, P.M., Ilardi, M.C., Borghuis, B.G., Chan, E., Weng, S., Auferkorte, O.N., Demb, J.B., and Berson, D.M. (2012). Form and function of the M4 cell, an intrinsically photosensitive retinal ganglion cell type contributing to geniculocortical vision. J Neurosci 32, $13608-13620$.

Fernandez, D.C., Fogerson, P.M., Lazzerini Ospri, L., Thomsen, M.B., Layne, R.M., Severin, D., Zhan, J., Singer, J.H., Kirkwood, A., Zhao, H., et al. (2018). Light Affects Mood and Learning through Distinct Retina-Brain Pathways. Cell 175, 71-84 e18.

Fernandez, D.C., Komal, R., Langel, J., Ma, J., Duy, P.Q., Penzo, M.A., Zhao, H., and Hattar, S. (2020). Retinal innervation tunes circuits that drive nonphotic entrainment to food. Nature $581,194-198$.

Franklin, G.P.a.K.B.J. (2001). The Mouse Brain in Stereotaxic Coordinates, Second edn (Harcourt Place, 32 Jamestown Road, London NW1 7BY, UK: Academic Press).

Gelegen, C., Gent, T.C., Ferretti, V., Zhang, Z., Yustos, R., Lan, F., Yang, Q., Overington, D.W., Vyssotski, A.L., van Lith, H.A., et al. (2014). Staying awake--a genetic region that hinders alpha2 adrenergic receptor agonist-induced sleep. Eur J Neurosci 40, 2311-2319. 
Brock et al.

Gelegen, C., Miracca, G., Ran, M.Z., Harding, E.C., Ye, Z., Yu, X., Tossell, K., Houston, C.M., Yustos, R., Hawkins, E.D., et al. (2018). Excitatory Pathways from the Lateral Habenula Enable Propofol-Induced Sedation. Curr Biol 28, 580-587 e585.

Golding, B., Pouchelon, G., Bellone, C., Murthy, S., Di Nardo, A.A., Govindan, S., Ogawa, M., Shimogori, T., Luscher, C., Dayer, A., et al. (2014). Retinal input directs the recruitment of inhibitory interneurons into thalamic visual circuits. Neuron 81, 1057-1069.

Guler, A.D., Ecker, J.L., Lall, G.S., Haq, S., Altimus, C.M., Liao, H.W., Barnard, A.R., Cahill, H., Badea, T.C., Zhao, H., et al. (2008). Melanopsin cells are the principal conduits for rod-cone input to non-image-forming vision. Nature 453, 102-105.

Hanna, L., Walmsley, L., Pienaar, A., Howarth, M., and Brown, T.M. (2017). Geniculohypothalamic GABAergic projections gate suprachiasmatic nucleus responses to retinal input. J Physiol 595, 3621-3649.

Harrington, M.E. (1997). The ventral lateral geniculate nucleus and the intergeniculate leaflet: interrelated structures in the visual and circadian systems. Neurosci Biobehav Rev 21, 705727.

Harrington, M.E., and Rusak, B. (1986). Lesions of the thalamic intergeniculate leaflet alter hamster circadian rhythms. J Biol Rhythms 1, 309-325.

Harrington, M.E., and Rusak, B. (1989). Photic responses of geniculo-hypothalamic tract neurons in the Syrian hamster. Vis Neurosci 2, 367-375.

Hatori, M., Le, H., Vollmers, C., Keding, S.R., Tanaka, N., Buch, T., Waisman, A., Schmedt, C., Jegla, T., and Panda, S. (2008). Inducible ablation of melanopsin-expressing retinal ganglion cells reveals their central role in non-image forming visual responses. PLoS One 3, e2451. 
Brock et al.

Hattar, S., Kumar, M., Park, A., Tong, P., Tung, J., Yau, K.W., and Berson, D.M. (2006). Central projections of melanopsin-expressing retinal ganglion cells in the mouse. J Comp Neurol 497, 326-349.

Hattar, S., Liao, H.W., Takao, M., Berson, D.M., and Yau, K.W. (2002). Melanopsin-containing retinal ganglion cells: architecture, projections, and intrinsic photosensitivity. Science 295, 1065-1070.

Horowitz, S.S., Blanchard, J.H., and Morin, L.P. (2004). Intergeniculate leaflet and ventral lateral geniculate nucleus afferent connections: An anatomical substrate for functional input from the vestibulo-visuomotor system. J Comp Neurol 474, 227-245.

Huang, L., Xi, Y., Peng, Y., Yang, Y., Huang, X., Fu, Y., Tao, Q., Xiao, J., Yuan, T., An, K., et al. (2019). A Visual Circuit Related to Habenula Underlies the Antidepressive Effects of Light Therapy. Neuron 102, 128-142 e128.

Huberman, A.D., Wei, W., Elstrott, J., Stafford, B.K., Feller, M.B., and Barres, B.A. (2009). Genetic identification of an On-Off direction-selective retinal ganglion cell subtype reveals a layer-specific subcortical map of posterior motion. Neuron 62, 327-334.

Huhman, K.L., and Albers, H.E. (1994). Neuropeptide Y microinjected into the suprachiasmatic region phase shifts circadian rhythms in constant darkness. Peptides 15, 1475-1478.

Huhman, K.L., Babagbemi, T.O., and Albers, H.E. (1995). Bicuculline blocks neuropeptide Yinduced phase advances when microinjected in the suprachiasmatic nucleus of Syrian hamsters. Brain Res 675, 333-336.

Huhman, K.L., Gillespie, C.F., Marvel, C.L., and Albers, H.E. (1996). Neuropeptide Y phase shifts circadian rhythms in vivo via a Y2 receptor. Neuroreport 7, 1249-1252. 
bioRxiv preprint doi: https://doi.org/10.1101/2022.02 24.481804 t this version posted February 25, 2022. The copyright holder for this preprint (which was not certified by peer review) is the author/funder, who has granted bioRxiv a license to display the preprint in perpetuity. It is made available under aCC-BY-NC-ND 4.0 International license.

Brock et al.

Inamura, N., Ono, K., Takebayashi, H., Zalc, B., and Ikenaka, K. (2011). Olig2 lineage cells generate GABAergic neurons in the prethalamic nuclei, including the zona incerta, ventral lateral geniculate nucleus and reticular thalamic nucleus. Dev Neurosci 33, 118-129.

Jager, P., Moore, G., Calpin, P., Durmishi, X., Salgarella, I., Menage, L., Kita, Y., Wang, Y., Kim, D.W., Blackshaw, S., et al. (2021). Dual midbrain and forebrain origins of thalamic inhibitory interneurons. Elife 10.

Jager, P., Ye, Z., Yu, X., Zagoraiou, L., Prekop, H.T., Partanen, J., Jessell, T.M., Wisden, W., Brickley, S.G., and Delogu, A. (2016b). Tectal-derived interneurons contribute to phasic and tonic inhibition in the visual thalamus. Nat Commun 7, 13579.

Janik, D., and Mrosovsky, N. (1994). Intergeniculate leaflet lesions and behaviorally-induced shifts of circadian rhythms. Brain Res 651, 174-182.

Jeong, Y., Dolson, D.K., Waclaw, R.R., Matise, M.P., Sussel, L., Campbell, K., Kaestner, K.H., and Epstein, D.J. (2011). Spatial and temporal requirements for sonic hedgehog in the regulation of thalamic interneuron identity. Development 138, 531-541.

Johnson, R.F., Moore, R.Y., and Morin, L.P. (1989). Lateral geniculate lesions alter circadian activity rhythms in the hamster. Brain Res Bull 22, 411-422.

Johnson, R.F., Smale, L., Moore, R.Y., and Morin, L.P. (1988). Lateral geniculate lesions block circadian phase-shift responses to a benzodiazepine. Proc Natl Acad Sci U S A 85, 5301-5304. Jones, J.R., Tackenberg, M.C., and McMahon, D.G. (2015). Manipulating circadian clock neuron firing rate resets molecular circadian rhythms and behavior. Nat Neurosci 18, 373375.

Kataoka, A., and Shimogori, T. (2008). Fgf8 controls regional identity in the developing thalamus. Development 135, 2873-2881. 
bioRxiv preprint doi: https://doi.org/10.1101/2022.02 24.481804 t this version posted February 25,2022 . The copyright holder for this preprint (which was not certified by peer review) is the author/funder, who has granted bioRxiv a license to display the preprint in perpetuity. It is made available under aCC-BY-NC-ND 4.0 International license.

Brock et al.

Kuroda, H., Fukushima, M., Nakai, M., Katayama, T., and Murakami, N. (1997). Daily wheel running activity modifies the period of free-running rhythm in rats via intergeniculate leaflet. Physiol Behav 61, 633-637.

Lewandowski, M.H., and Blasiak, T. (2004). Slow oscillation circuit of the intergeniculate leaflet. Acta Neurobiol Exp (Wars) 64, 277-288.

Lewandowski, M.H., and Usarek, A. (2002). Effects of intergeniculate leaflet lesions on circadian rhythms in the mouse. Behav Brain Res 128, 13-17.

Lima, L.B., Bueno, D., Leite, F., Souza, S., Goncalves, L., Furigo, I.C., Donato, J., Jr., and Metzger, M. (2017). Afferent and efferent connections of the interpeduncular nucleus with special reference to circuits involving the habenula and raphe nuclei. J Comp Neurol 525, 2411-2442. Longair, M.H., Baker, D.A., and Armstrong, J.D. (2011). Simple Neurite Tracer: open source software for reconstruction, visualization and analysis of neuronal processes. Bioinformatics $27,2453-2454$.

Lucas, R.J., Hattar, S., Takao, M., Berson, D.M., Foster, R.G., and Yau, K.W. (2003). Diminished pupillary light reflex at high irradiances in melanopsin-knockout mice. Science 299, 245-247. Lupi, D., Oster, H., Thompson, S., and Foster, R.G. (2008). The acute light-induction of sleep is mediated by OPN4-based photoreception. Nat Neurosci 11, 1068-1073.

Marchant, E.G., Watson, N.V., and Mistlberger, R.E. (1997). Both neuropeptide $Y$ and serotonin are necessary for entrainment of circadian rhythms in mice by daily treadmill running schedules. J Neurosci 17, 7974-7987.

Martinez-Ferre, A., and Martinez, S. (2012). Molecular regionalization of the diencephalon. Front Neurosci 6, 73.

Matsuda, T., and Cepko, C.L. (2007). Controlled expression of transgenes introduced by in vivo electroporation. Proc Natl Acad Sci U S A 104, 1027-1032. 
Brock et al.

Maywood, E.S., Okamura, H., and Hastings, M.H. (2002). Opposing actions of neuropeptide $Y$ and light on the expression of circadian clock genes in the mouse suprachiasmatic nuclei. Eur J Neurosci 15, 216-220.

Maywood, E.S., Smith, E., Hall, S.J., and Hastings, M.H. (1997). A thalamic contribution to arousal-induced, non-photic entrainment of the circadian clock of the Syrian hamster. Eur J Neurosci 9, 1739-1747.

Mazuski, C., Abel, J.H., Chen, S.P., Hermanstyne, T.O., Jones, J.R., Simon, T., Doyle, F.J., 3rd, and Herzog, E.D. (2018). Entrainment of Circadian Rhythms Depends on Firing Rates and Neuropeptide Release of VIP SCN Neurons. Neuron 99, 555-563 e555.

Meyer-Bernstein, E.L., and Morin, L.P. (1996). Differential serotonergic innervation of the suprachiasmatic nucleus and the intergeniculate leaflet and its role in circadian rhythm modulation. J Neurosci 16, 2097-2111.

Miller, A.M., Obermeyer, W.H., Behan, M., and Benca, R.M. (1998). The superior colliculuspretectum mediates the direct effects of light on sleep. Proc Natl Acad Sci U S A 95, 89578962.

Mo, A., Mukamel, E.A., Davis, F.P., Luo, C., Henry, G.L., Picard, S., Urich, M.A., Nery, J.R., Sejnowski, T.J., Lister, R., et al. (2015). Epigenomic Signatures of Neuronal Diversity in the Mammalian Brain. Neuron 86, 1369-1384.

Monavarfeshani, A., Sabbagh, U., and Fox, M.A. (2017). Not a one-trick pony: Diverse connectivity and functions of the rodent lateral geniculate complex. Vis Neurosci 34, E012.

Monory, K., Massa, F., Egertová, M., Eder, M., Blaudzun, H., Westenbroek, R., Kelsch, W., Jacob, W., Marsch, R., Ekker, M., et al. (2006). The endocannabinoid system controls key epileptogenic circuits in the hippocampus. Neuron 51, 455-466. 
Brock et al.

Moore, R.Y. (1989). The geniculohypothalamic tract in monkey and man. Brain Res 486, 190194.

Moore, R.Y., Weis, R., and Moga, M.M. (2000). Efferent projections of the intergeniculate leaflet and the ventral lateral geniculate nucleus in the rat. J Comp Neurol 420, 398-418.

Morin, L.P. (2013). Neuroanatomy of the extended circadian rhythm system. Exp Neurol 243, 4-20.

Morin, L.P. (2015). A Path to Sleep Is through the Eye. eNeuro 2.

Morin, L.P., and Blanchard, J. (1995). Organization of the hamster intergeniculate leaflet: NPY and ENK projections to the suprachiasmatic nucleus, intergeniculate leaflet and posterior limitans nucleus. Vis Neurosci 12, 57-67.

Morin, L.P., and Blanchard, J.H. (1999). Forebrain connections of the hamster intergeniculate leaflet: comparison with those of ventral lateral geniculate nucleus and retina. Vis Neurosci $16,1037-1054$.

Morin, L.P., and Blanchard, J.H. (2001). Neuromodulator content of hamster intergeniculate leaflet neurons and their projection to the suprachiasmatic nucleus or visual midbrain. J Comp Neurol 437, 79-90.

Morin, L.P., and Blanchard, J.H. (2005). Descending projections of the hamster intergeniculate leaflet: relationship to the sleep/arousal and visuomotor systems. J Comp Neurol 487, 204216.

Morin, L.P., and Studholme, K.M. (2009). Millisecond light pulses make mice stop running, then display prolonged sleep-like behavior in the absence of light. J Biol Rhythms 24, 497-508. Morin, L.P., and Studholme, K.M. (2014a). Light pulse duration differentially regulates mouse locomotor suppression and phase shifts. J Biol Rhythms 29, 346-354. 
Brock et al.

Morin, L.P., and Studholme, K.M. (2014b). Retinofugal projections in the mouse. J Comp Neurol 522, 3733-3753.

Mrosovsky, N., and Hattar, S. (2003). Impaired masking responses to light in melanopsinknockout mice. Chronobiol Int 20, 989-999.

Mrosovsky, N., Lucas, R.J., and Foster, R.G. (2001). Persistence of masking responses to light in mice lacking rods and cones. J Biol Rhythms 16, 585-588.

Muindi, F., Zeitzer, J.M., Colas, D., and Heller, H.C. (2013). The acute effects of light on murine sleep during the dark phase: importance of melanopsin for maintenance of light-induced sleep. Eur J Neurosci 37, 1727-1736.

Nakagawa, Y. (2019). Development of the thalamus: From early patterning to regulation of cortical functions. Wiley Interdiscip Rev Dev Biol 8, e345.

Osakada, F., and Callaway, E.M. (2013). Design and generation of recombinant rabies virus vectors. Nat Protoc 8, 1583-1601.

Panda, S., Provencio, I., Tu, D.C., Pires, S.S., Rollag, M.D., Castrucci, A.M., Pletcher, M.T., Sato, T.K., Wiltshire, T., Andahazy, M., et al. (2003). Melanopsin is required for non-image-forming photic responses in blind mice. Science 301, 525-527.

Panda, S., Sato, T.K., Castrucci, A.M., Rollag, M.D., DeGrip, W.J., Hogenesch, J.B., Provencio, I., and Kay, S.A. (2002). Melanopsin (Opn4) requirement for normal light-induced circadian phase shifting. Science 298, 2213-2216.

Pang, D.S., Robledo, C.J., Carr, D.R., Gent, T.C., Vyssotski, A.L., Caley, A., Zecharia, A.Y., Wisden, W., Brickley, S.G., and Franks, N.P. (2009). An unexpected role for TASK-3 potassium channels in network oscillations with implications for sleep mechanisms and anesthetic action. Proc Natl Acad Sci U S A 106, 17546-17551. 
Brock et al.

Paxinos, and Franklin (2001). The Mouse Brain in Stereotaxic Coordinates, Second edn (Harcourt Place, 32 Jamestown Road, London NW1 7BY, UK: Academic Press).

Peters, R.V., Aronin, N., and Schwartz, W.J. (1996). c-Fos expression in the rat intergeniculate leaflet: photic regulation, co-localization with Fos-B, and cellular identification. Brain Res 728, 231-241.

Pickard, G.E. (1985). Bifurcating axons of retinal ganglion cells terminate in the hypothalamic suprachiasmatic nucleus and the intergeniculate leaflet of the thalamus. Neurosci Lett 55, 211-217.

Pickard, G.E. (1994). Intergeniculate leaflet ablation alters circadian rhythms in the mouse. Neuroreport 5, 2186-2188.

Pickard, G.E., Ralph, M.R., and Menaker, M. (1987). The intergeniculate leaflet partially mediates effects of light on circadian rhythms. J Biol Rhythms 2, 35-56.

Pilorz, V., Tam, S.K., Hughes, S., Pothecary, C.A., Jagannath, A., Hankins, M.W., Bannerman, D.M., Lightman, S.L., Vyazovskiy, V.V., Nolan, P.M., et al. (2016). Melanopsin Regulates Both Sleep-Promoting and Arousal-Promoting Responses to Light. PLoS Biol 14, e1002482.

Pratt, B.L., and Goldman, B.D. (1986). Activity rhythms and photoperiodism of Syrian hamsters in a simulated burrow system. Physiol Behav 36, 83-89.

$\mathrm{Pu}, \mathrm{M}$. , and Pickard, G.E. (1996). Ventral lateral geniculate nucleus afferents to the suprachiasmatic nucleus in the cat. Brain Res 725, 247-251.

Puelles, L. (2019). Survey of Midbrain, Diencephalon, and Hypothalamus Neuroanatomic Terms Whose Prosomeric Definition Conflicts With Columnar Tradition. Front Neuroanat 13, 20. 
Brock et al.

Puelles, L., Diaz, C., Stuhmer, T., Ferran, J.L., Martinez-de la Torre, M., and Rubenstein, J.L.R. (2020). LacZ-reporter mapping of Dlx5/6 expression and genoarchitectural analysis of the postnatal mouse prethalamus. J Comp Neurol.

Puelles, L., Harrison, M., Paxinos, G., and Watson, C. (2013). A developmental ontology for the mammalian brain based on the prosomeric model. Trends Neurosci 36, 570-578.

Puelles, L., and Rubenstein, J.L. (1993). Expression patterns of homeobox and other putative regulatory genes in the embryonic mouse forebrain suggest a neuromeric organization. Trends Neurosci 16, 472-479.

Puelles, L., and Rubenstein, J.L. (2003). Forebrain gene expression domains and the evolving prosomeric model. Trends Neurosci 26, 469-476.

Quattrocchi, T., Micali, E., Gentile, A., La Ferrera, E.G., Barbaro, L., Ciarcia, S., Corrado, F., Di Costa, M., Fazio, R., Licenziato, R., et al. (2015). Effects of a phyto complex on well-being of climacteric women. J Obstet Gynaecol Res 41, 1093-1098.

Quattrochi, L.E., Stabio, M.E., Kim, I., Ilardi, M.C., Michelle Fogerson, P., Leyrer, M.L., and Berson, D.M. (2019). The M6 cell: A small-field bistratified photosensitive retinal ganglion cell. J Comp Neurol 527, 297-311.

Redlin, U. (2001). Neural basis and biological function of masking by light in mammals: suppression of melatonin and locomotor activity. Chronobiol Int 18, 737-758.

Rivlin-Etzion, M., Zhou, K., Wei, W., Elstrott, J., Nguyen, P.L., Barres, B.A., Huberman, A.D., and Feller, M.B. (2011). Transgenic mice reveal unexpected diversity of on-off directionselective retinal ganglion cell subtypes and brain structures involved in motion processing. J Neurosci 31, 8760-8769. 
bioRxiv preprint doi: https://doi.org/10.1101/2022.02 24.481804 t this version posted February 25, 2022. The copyright holder for this preprint (which was not certified by peer review) is the author/funder, who has granted bioRxiv a license to display the preprint in perpetuity. It is made available under aCC-BY-NC-ND 4.0 International license.

Brock et al.

Rompani, S.B., Mullner, F.E., Wanner, A., Zhang, C., Roth, C.N., Yonehara, K., and Roska, B. (2017). Different Modes of Visual Integration in the Lateral Geniculate Nucleus Revealed by Single-Cell-Initiated Transsynaptic Tracing. Neuron 93, 767-776 e766.

Rosenwasser, A.M., Boulos, Z., and Terman, M. (1983a). Circadian feeding and drinking rhythms in the rat under complete and skeleton photoperiods. Physiology \& Behavior 30, 353359.

Rosenwasser, A.M., Boulos, Z., and Terman, M. (1983b). Circadian feeding and drinking rhythms in the rat under complete and skeleton photoperiods. Physiol Behav 30, 353-359. Rubenstein, J.L., Martinez, S., Shimamura, K., and Puelles, L. (1994). The embryonic vertebrate forebrain: the prosomeric model. Science $266,578-580$.

Rupp, A.C., Ren, M., Altimus, C.M., Fernandez, D.C., Richardson, M., Turek, F., Hattar, S., and Schmidt, T.M. (2019). Distinct ipRGC subpopulations mediate light's acute and circadian effects on body temperature and sleep. Elife 8.

Sabbagh, U., Govindaiah, G., Somaiya, R.D., Ha, R.V., Wei, J.C., Guido, W., and Fox, M.A. (2020). Diverse GABAergic neurons organize into subtype-specific sublaminae in the ventral lateral geniculate nucleus. J Neurochem.

Sakai, K. (2014). Single unit activity of the suprachiasmatic nucleus and surrounding neurons during the wake-sleep cycle in mice. Neuroscience 260, 249-264.

Schindelin, J., Arganda-Carreras, I., Frise, E., Kaynig, V., Longair, M., Pietzsch, T., Preibisch, S., Rueden, C., Saalfeld, S., Schmid, B., et al. (2012). Fiji: an open-source platform for biologicalimage analysis. Nat Methods 9, 676-682.

Schmidt, T.M., and Kofuji, P. (2011). Structure and function of bistratified intrinsically photosensitive retinal ganglion cells in the mouse. J Comp Neurol 519, 1492-1504. 
bioRxiv preprint doi: https://doi.org/10.1101/2022.02 24.481804 this version posted February 25,2022 . The copyright holder for this preprint (which was not certified by peer review) is the author/funder, who has granted bioRxiv a license to display the preprint in perpetuity. It is made available under aCC-BY-NC-ND 4.0 International license.

Brock et al.

Sellers, K., Zyka, V., Lumsden, A.G., and Delogu, A. (2014). Transcriptional control of GABAergic neuronal subtype identity in the thalamus. Neural Dev 9, 14.

Shi, H.Y., Xu, W., Guo, H., Dong, H., Qu, W.M., and Huang, Z.L. (2019). Lesion of intergeniculate leaflet GABAergic neurons attenuates sleep in mice exposed to light. Sleep.

Shi, H.Y., Xu, W., Guo, H., Dong, H., Qu, W.M., and Huang, Z.L. (2020). Lesion of intergeniculate leaflet GABAergic neurons attenuates sleep in mice exposed to light. Sleep 43.

Shibata, S., and Moore, R.Y. (1993). Neuropeptide Y and optic chiasm stimulation affect suprachiasmatic nucleus circadian function in vitro. Brain Res 615, 95-100.

Siegert, S., Scherf, B.G., Del Punta, K., Didkovsky, N., Heintz, N., and Roska, B. (2009). Genetic address book for retinal cell types. Nat Neurosci 12, 1197-1204.

Smith, V.M., Jeffers, R.T., and Antle, M.C. (2015). Serotonergic enhancement of circadian responses to light: role of the raphe and intergeniculate leaflet. Eur J Neurosci 42, 2805-2817. Sonoda, T., and Schmidt, T.M. (2016). Re-evaluating the Role of Intrinsically Photosensitive Retinal Ganglion Cells: New Roles in Image-Forming Functions. Integr Comp Biol 56, 834-841. Stabio, M.E., Sabbah, S., Quattrochi, L.E., Ilardi, M.C., Fogerson, P.M., Leyrer, M.L., Kim, M.T., Kim, I., Schiel, M., Renna, J.M., et al. (2018). The M5 Cell: A Color-Opponent Intrinsically Photosensitive Retinal Ganglion Cell. Neuron 97, 251.

Stephan, F.K. (1983a). Circadian rhythms in the rat: Constant darkness, entrainment to T cycles and to skeleton photoperiods. Physiology \& Behavior 30, 451-462.

Stephan, F.K. (1983b). Circadian rhythms in the rat: constant darkness, entrainment to T cycles and to skeleton photoperiods. Physiol Behav 30, 451-462.

Sumbul, U., Song, S., McCulloch, K., Becker, M., Lin, B., Sanes, J.R., Masland, R.H., and Seung, H.S. (2014). A genetic and computational approach to structurally classify neuronal types. Nat Commun 5, 3512. 
Brock et al.

Suzuki-Hirano, A., Ogawa, M., Kataoka, A., Yoshida, A.C., Itoh, D., Ueno, M., Blackshaw, S., and Shimogori, T. (2011). Dynamic spatiotemporal gene expression in embryonic mouse thalamus. J Comp Neurol 519, 528-543.

Tsai, J.W., Hannibal, J., Hagiwara, G., Colas, D., Ruppert, E., Ruby, N.F., Heller, H.C., Franken, P., and Bourgin, P. (2009). Melanopsin as a sleep modulator: circadian gating of the direct effects of light on sleep and altered sleep homeostasis in Opn4(-/-) mice. PLoS Biol 7, e1000125.

Twente Jr., J.W. (1955). Some Aspects of Habitat Selection and Other Behavior of CavernDwelling Bats. Ecology 36, 706-732.

Vidal, L., Blanchard, J., and Morin, L.P. (2005). Hypothalamic and zona incerta neurons expressing hypocretin, but not melanin concentrating hormone, project to the hamster intergeniculate leaflet. Neuroscience 134, 1081-1090.

Virolainen, S.M., Achim, K., Peltopuro, P., Salminen, M., and Partanen, J. (2012). Transcriptional regulatory mechanisms underlying the GABAergic neuron fate in different diencephalic prosomeres. Development 139, 3795-3805.

Vrang, N., Mrosovsky, N., and Mikkelsen, J.D. (2003). Afferent projections to the hamster intergeniculate leaflet demonstrated by retrograde and anterograde tracing. Brain Res Bull 59, 267-288.

Vue, T.Y., Aaker, J., Taniguchi, A., Kazemzadeh, C., Skidmore, J.M., Martin, D.M., Martin, J.F., Treier, M., and Nakagawa, Y. (2007). Characterization of progenitor domains in the developing mouse thalamus. J Comp Neurol 505, 73-91.

Yuge, K., Kataoka, A., Yoshida, A.C., Itoh, D., Aggarwal, M., Mori, S., Blackshaw, S., and Shimogori, T. (2011). Region-specific gene expression in early postnatal mouse thalamus. J Comp Neurol 519, 544-561. 
bioRxiv preprint doi: https://doi org/10.1101/2022 0224 481804 this version posted February 25, 2022. The copyright holder for this preprint (which was not certified by peer review) is the author/funder, who has granted bioRxiv a license to display the preprint in perpetuity. It is made available under aCC-BY-NC-ND 4.0 International license.

Brock et al.

Zhang, D.X., and Rusak, B. (1989). Photic sensitivity of geniculate neurons that project to the suprachiasmatic nuclei or the contralateral geniculate. Brain Res 504, 161-164.

Zhang, Z., Liu, W.Y., Diao, Y.P., Xu, W., Zhong, Y.H., Zhang, J.Y., Lazarus, M., Liu, Y.Y., Qu, W.M., and Huang, Z.L. (2019). Superior Colliculus GABAergic Neurons Are Essential for Acute Dark Induction of Wakefulness in Mice. Curr Biol 29, 637-644 e633.

Zhivomirov, H. (2019). On the Development of STFT-analysis and ISTFT-synthesis Routines and their Practical Implementation. 
bioRxiv preprint doi: https://doi.org/10.1101/2022.02.24.481804; this version posted February 25, 2022. The copyright holder for this preprint (which was not certified by peer review) is the author/funder, who has granted bioRxiv a license to display the preprint in perpetuity. It is made available under aCC-BY-NC-ND 4.0 International license.

Brock et al.

Extended figure and tables

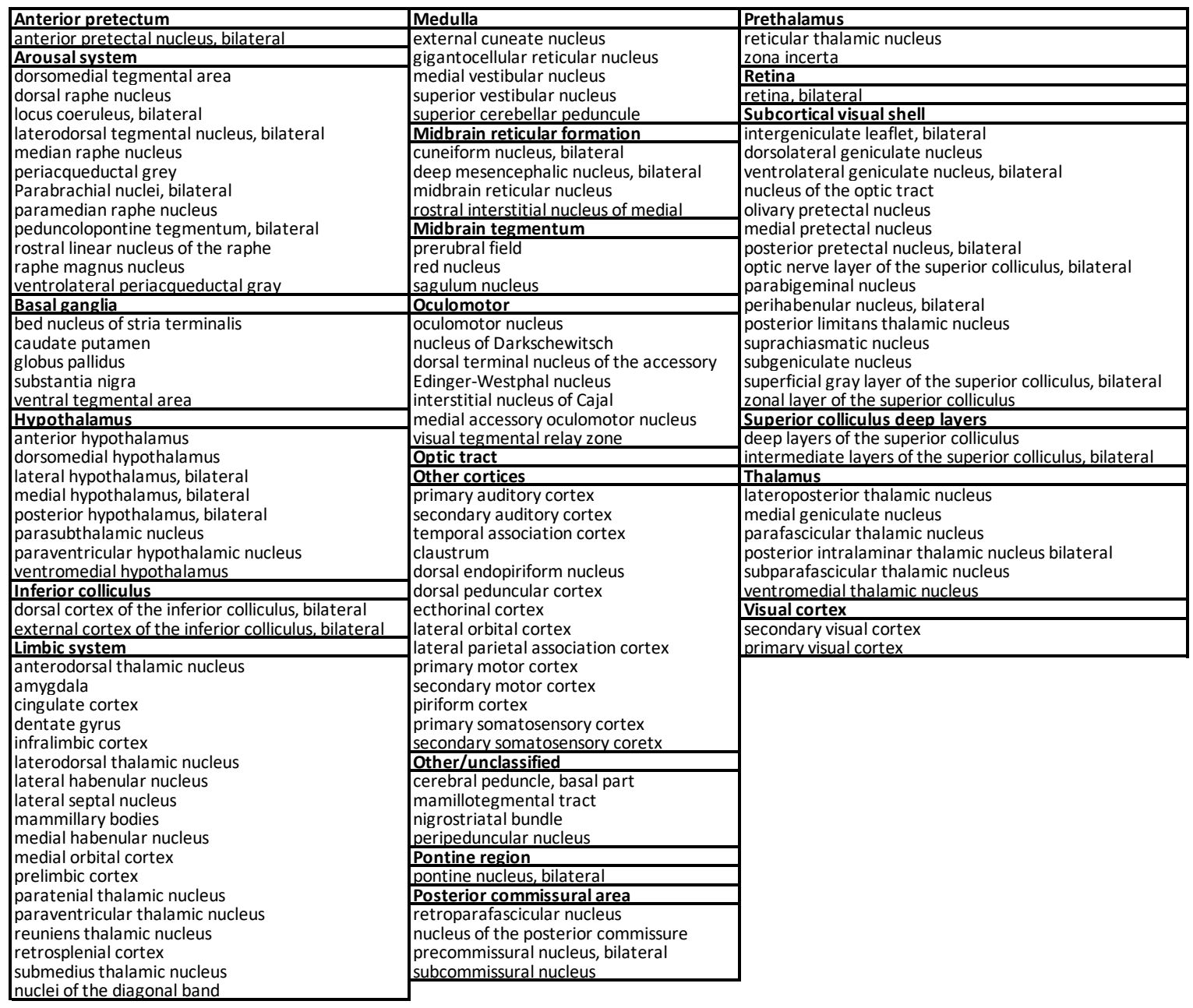

Table 4-1

Anatomical classification of regions harbouring presynaptic input to Sox $14^{+}$neurons. The classification used to cluster anatomical regions containing cells transsynaptically labelled by the RVdG vector is based on the atlas of the mouse brain by Paxinos and Franklin (Paxinos and Franklin, 2001). 
bioRxiv preprint doi: https://doi.org/10.1101/2022.02.24.481804; this version posted February 25, 2022. The copyright holder for this preprint (which was not certified by peer review) is the author/funder, who has granted bioRxiv a license to display the preprint in perpetuity. It is made available under aCC-BY-NC-ND 4.0 International license.

Brock et al.

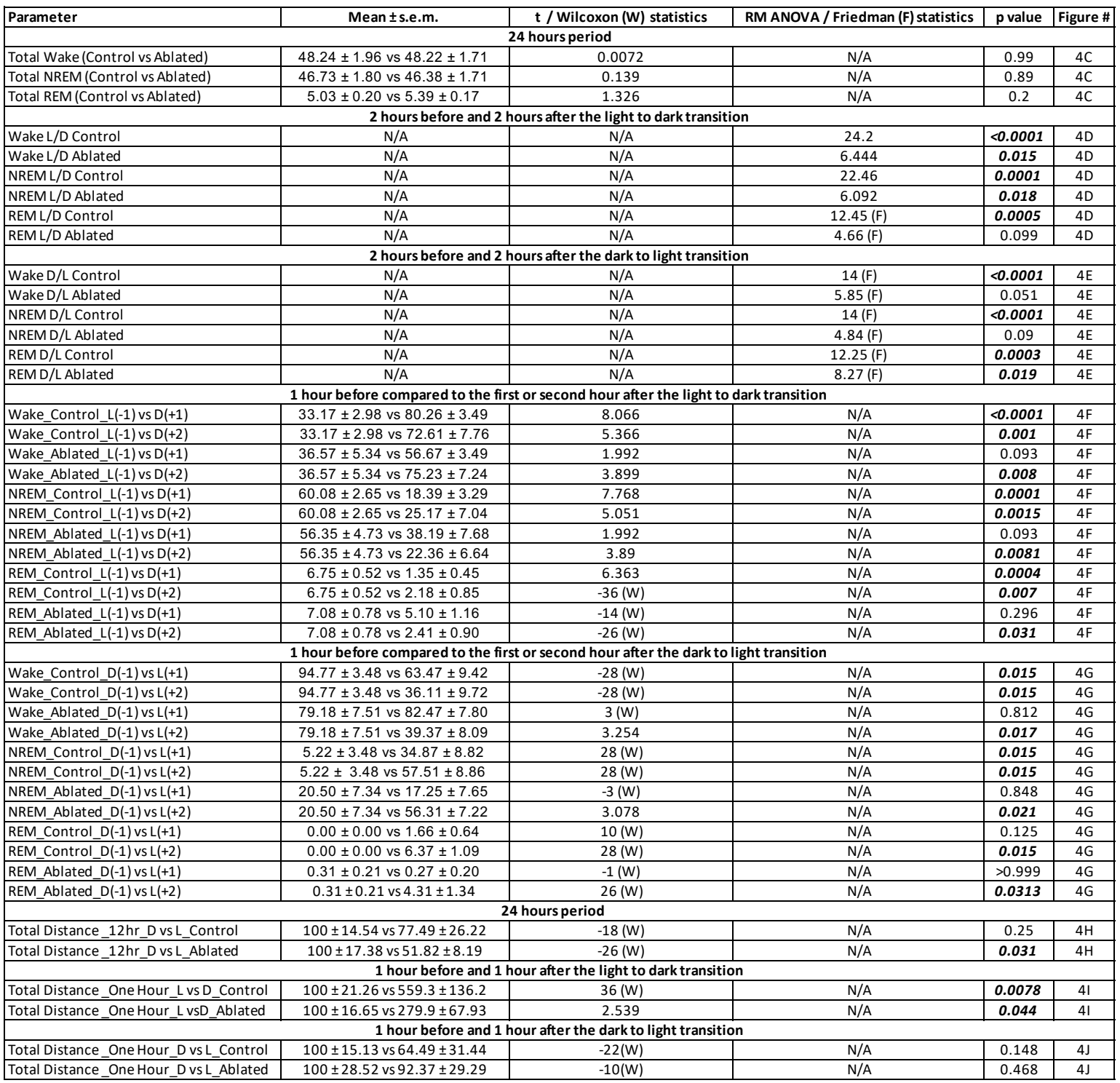

Table 6-1

Statistical treatment of EEG/EMG data. Mean values, experimental error and the parametric and non-parametric tests used to calculate statistical significance. F indicates Friedman test; W indicates Wilcoxon. 
bioRxiv preprint doi: https://doi.org/10.1101/2022.02.24.481804; this version posted February 25, 2022. The copyright holder for this preprint (which was not certified by peer review) is the author/funder, who has granted bioRxiv a license to display the preprint in perpetuity. It is made available under aCC-BY-NC-ND 4.0 International license.

Brock et al.

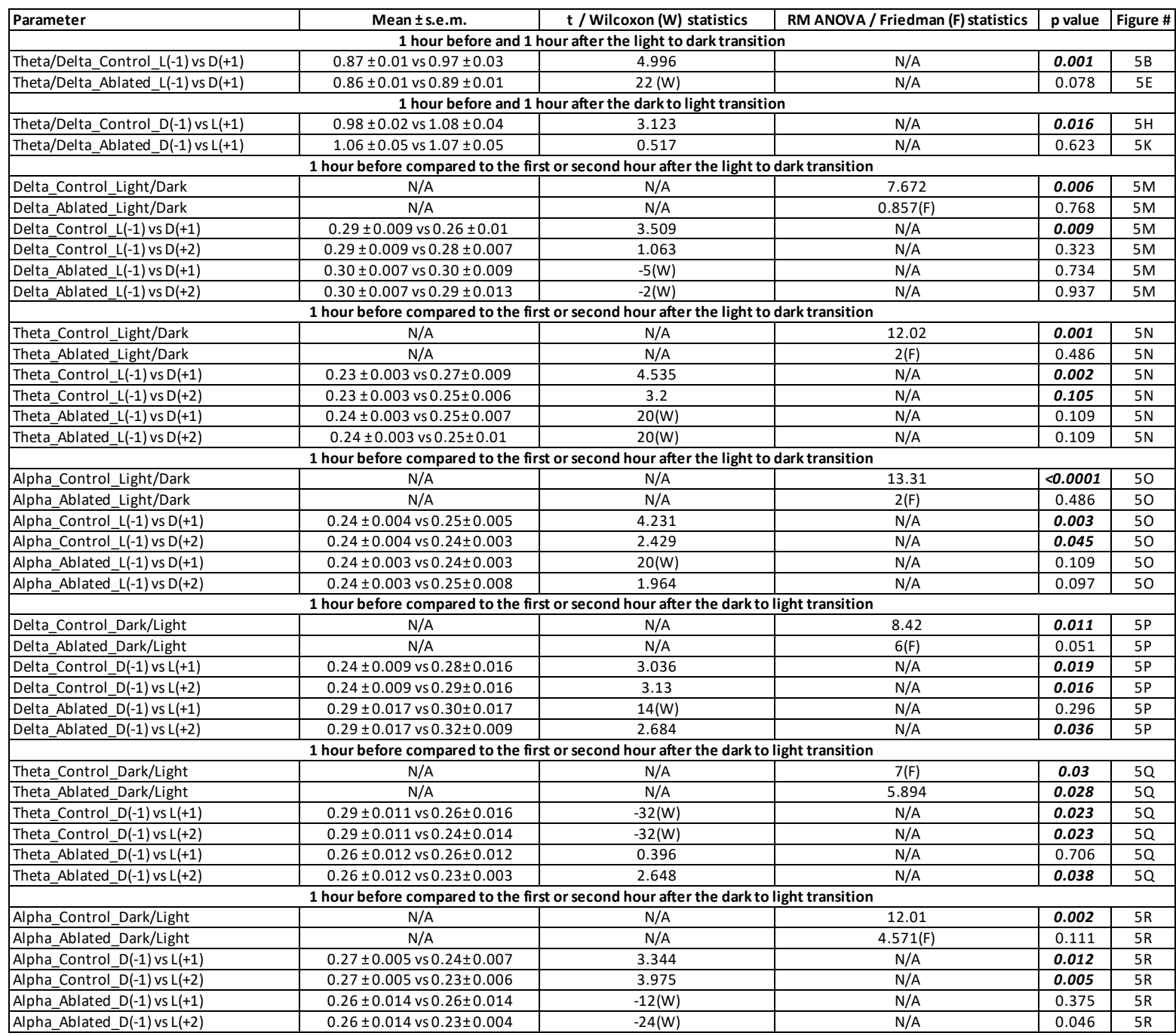

\section{Table7-1}

Statistical treatment of EEG/EMG data. Mean values, experimental error and the parametric and non-parametric tests used to calculate statistical significance. F indicates Friedman test; W indicates Wilcoxon. 
bioRxiv preprint doi: https://doi.org/10.1101/2022.02.24.481804; this version posted February 25, 2022. The copyright holder for this preprint (which was not certified by peer review) is the author/funder, who has granted bioRxiv a license to display the preprint in perpetuity. It is made available under aCC-BY-NC-ND 4.0 International license.

Brock et al.
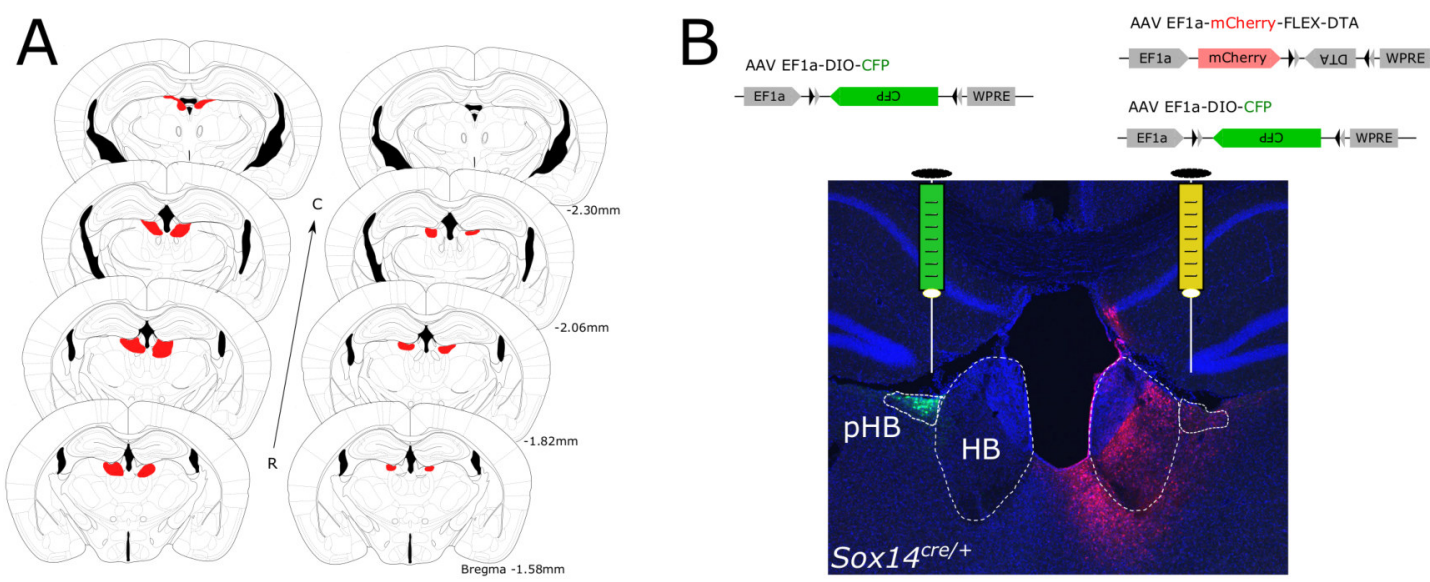

\section{Figure 9-1}

Evaluation of the extent of Sox $14^{+} \mathrm{pHB}$ cell ablation. $\boldsymbol{A}$, Evaluation of the AAV1-EF1 $\alpha$-mCherry-flex-dta spread upon stereotaxic injection in the pHB region of Sox $14^{\mathrm{Cre} /+}$ mice. Two representative brains depicting the variability and location of mCherry labelled cells (red) in a larger injection (left) and smaller injection (right). $\boldsymbol{B}$, Illustrative example of the strategy used ablate Sox $14^{+}$neurons in the pHB. The AAV1-EF1 $\alpha$-DIO-CFP Credependent AAV vector (green) was injected stereotaxically in the left pHB. An equimolar mixture of the EF1 $\alpha-$ DIO-CFP and the EF1 $\alpha$-mCherry-flex-dta was injected in the right pHB. Lack of CFP signal on the right pHB indicate efficient ablation of all infected cells. 